\title{
Myter om velferd og velferdsstaten
}

Karen Christensen og Liv Johanne Syltevik (red.) 
Myter om velferd og velferdsstaten 

Karen Christensen og Liv Johanne Syltevik (red.)

\section{Myter om velferd og velferdsstaten}


(C) Karen Christensen, Liv Johanne Syltevik, Hans-Tore Hansen, Ingrid Rindal Lundeberg, Atle Møen og Kristoffer Chelsom Vogt.

Dette verket omfattes av bestemmelsene i Lov om opphavsretten til åndsverk m.v. av 1961.

Verket utgis Open Access under betingelsene i Creative Commons-lisensen CC BY-NC 4.0. Denne lisensen lar andre dele og bearbeide verket for ikke-kommersielle formål, under forutsetning av at det oppgis korrekt kreditering, lenke til lisens og indikasjon på om endringer er blitt gjort. Du kan gjøre dette på enhver rimelig måte, men uten at det kan forstås slik at lisensgiver bifaller deg eller din bruk av materialet. Lisensvilkår: https://creativecommons.org/licenses/by-nc/4.0/legalcode.no

Boka er utgitt med støtte fra publiseringsfondet ved Universitetet i Bergen.

ISBN PDF: 978-82-02-60414-1

ISBN EPUB: 978-82-02-62550-4

ISBN HTML: 978-82-02-62551-1

ISBN XML: 978-82-02-62552-8

DOI: https://doi.org/10.23865/noasp.47

Dette er en fagfellevurdert antologi.

Cover Design: Cappelen Damm

Cappelen Damm Akademisk/NOASP

noasp@cappelendamm.no 


\section{Innhold}

Sammendrag............................................................................................ 7

Myter om velferd 0 g velferdsstaten ........................................................... 9

Artikkel 1 Myten om velferdsstaten ........................................................15

Hans-Tore Hansen

Artikkel 2 Myten om at ein stor stat fører til eit svakt samfunn ...................39

Atle Møen

Artikkel 3 Myten om velferdsavhengighet .....................................................59

Kristoffer Chelsom Vogt

Artikkel 4 Myten om eldrebølgen...................................................................... 75

Karen Christensen

Artikkel 5 Myten om alenemødrene og velferdsstaten .................................99

Liv Johanne Syltevik

Artikkel 6 Myten om fengselspinen .................................................... 123

Ingrid Rindal Lundeberg

Om forfatterne ................................................................................... 147 



\section{Sammendrag}

Utbyggingen av velferdsstaten i etterkrigstiden hører til en av de mest sentrale endringer i det norske samfunn, og er ofte et tema i den offentlige debatt. Når bestemte forestillinger om velferdsstaten utvikles og de ikke lenger bygger på systematiske analyser, men på ideer og holdninger, kan de bli til myter. At det er snakk om myter, må imidlertid dokumenteres, og her spiller samfunnsforskningen en viktig rolle. Denne boken tilbakeviser og nyanserer sentrale myter i den offentlige debatt om velferdsstaten. Boken er bygget opp som en antologi, skrevet av seks velferdssosiologer fra Universitetet i Bergen. Den første artikkelen gir en innføring i historien om Myten om velferdsstaten, en bok utgitt av Pax i 1970, siden revidert noen år etter og med en oppfølger i 1995, 25 år etter. Boken ble en brannfakkel i den sosialpolitiske debatt, fordi den kritiserte velferdsstaten for ikke å håndtere fattigdomsproblemet. Selv om dette problemet, relativt sett, er redusert, utgjør de etterfølgende artiklene om fem aktuelle velferdsmyter en argumentasjon for, at det, innenfor velferdsstatens rammer, er rom for nye viktige kritiske diskusjoner. Én myte handler om at en sterk stat ikke kan forenes med et aktivt samfunn med stor grad av frivillighet. En annen handler om at velferd skaper avhengighet. En tredje handler om eldrebølgen. En fjerde handler om at alenemødre antas å lure til seg velferd. Og endelig handler en siste myte om at kriminalitet må møtes med straff og 'fengselspine'. Artiklene er samlet sett et bidrag til å gjøre debatten om velferdsstaten rikere og mer dynamisk.

\section{Abstract}

Post-war expansion of the welfare state is one of the most central changes in Norwegian society today and is often a topic in public debate. When certain conceptions about the welfare state are developed and they are no longer based on systematic analyses but rather ideas and attitudes, they can turn into myths. However, to be termed myths requires documentation, and here social research plays an important role. This book rejects and elaborates central myths in the public debate about the welfare state. The book is structured as an anthology, written by six welfare sociologists at the University of Bergen. The first article introduces the history of The Myth of the Welfare State, a book published by Pax in 1970, then revised a few years later, and with a follow-up version in 1995, 25 years after that. The book became a flaming light within the social policy debate, because it criticized the welfare state for not solving the problem of poverty. Although this problem, relatively seen, is reduced, the following five articles show that, within the framework of the welfare state, there is room for new important critical discussions. One myth focuses on the idea that a combination of a comprehensive state and an active civil society with much voluntary work is not possible. Another concerns the idea that welfare results in dependency. A third is about the "Elder Boom". A fourth concerns single mothers and assumes that these unlawfully try to get access to welfare. And finally, the last discusses the ideas that crime should result in punishment and "prison pain". Together, the articles are a contribution to make the debate about the welfare state richer and more dynamic. 



\section{Myter om velferd og velferdsstaten}

\section{Innledning}

Formålet med denne boken er å gi innsikt i den norske velferdsstaten fra et myteperspektiv. Ved å ta frem sentrale myter om velferd og velferdsstaten ønsker vi å bidra til den offentlige debatt om sentrale sider ved det norske samfunn, et samfunn som har gjort velferdsstaten til en av etterkrigstidens mest sentrale institusjoner.

En myte er et gresk et ord for tale, fortelling eller muntlig beretning. Opprinnelig er myten en betegnelse for muntlig overleverte religiøse forestillinger om guder eller verdens opprinnelse. I dagligtale i dag brukes begrepet om kollektive forestillinger eller tro som ikke har basis i fakta. Det er dermed ofte et element av illusjon, forvrengning eller usannhet som impliseres når begrepet myte brukes. Her bruker vi begrepet for å understreke at forestillinger i form av myter om velferd og velferdsstaten kun er basert på en del av et virkelighetsbilde. Det betyr ikke at mytene nødvendigvis er usanne eller utelukkende basert på spekulasjoner. Men det betyr at deler av bildet er utelatt eller gjemt vekk, og med dette fremmes så en bestemt forestilling om et fenomen. Vi ønsker å vise at samfunnsforskningen kan tilføre den offentlige debatt mer innsikt i 'det ufullstendige' som alltid karakteriserer en myte. Generelt sett kan imidlertid forskning både produsere, reprodusere og problematisere myter. Det er det siste som er vårt mål her.

Vi har valgt ut en rekke myter om velferd og velferdsstaten som vi mener har og har hatt en viktig betydning for den offentlige velferdsdebatt på en rekke områder. De enkelte bidrag handler i den forstand om å tilbakevise eller nyansere forestillinger som er innbakt i de aktuelle mytene. Men bidragene peker også ut ulike aspekter og diskusjoner som er knyttet til myter.

Boken er bygget opp som en antologi med artikler om myter. Den første artikkelen, skrevet av Hans-Tore Hansen, tar for seg 
mytediskusjonen som har vært knyttet til velferdsstaten historisk. Hansen presenterer og diskuterer tre bøker som tidligere er skrevet på området, og med 'Myten om velferdsstaten' i tittelen, den første i 1970, den siste i 1995. I artikkelen knytter Hansen diskusjonen til det som i sosiologien kalles 'public sociology'. Dette fordi bøkene er bidrag til en offentlig debatt med både akademiske og ikke-akademiske stemmer. Han diskuterer også relevansen av disse tidlige diskusjonene for dagens velferdsstat. Myten om velferdsstaten handler om at 'velferdsstaten' presenterer seg som en velfungerende velferdsstat som gir lik adgang for alle. Bidragsyterne i disse bøkene kritiserer dette, og legger frem sentrale eksempler på hvordan velferdsstaten svikter de svakeste. Det handler med andre ord om tilbakevisningen av påstander som at det ikke finnes fattigdom, og at det ikke er mennesker som sviktes. Ved å diskutere den endrete betydning som fattigdom har fått i det norske samfunnet i dag - og særlig i relasjon til andre deler av verden - argumenterer Hansen for viktigheten av den historiske konteksten for velferdsmytediskusjoner. De resterende artikler handler om velferdsmyter innenfor dagens samfunnskontekst, i en situasjon med en relativt sett begrenset og kontrollert fattigdom.

Atle Møen bidrar med den mest generelle velferdsmytediskusjonen av de resterende fem bidragene. Møen gir innblikk i hvordan en myte brukes til å kritisere en samfunnsmessig organisering slik den velferdsstaten representerer. Med utgangspunkt i et republikansk perspektiv på statsmakten - det vil si et perspektiv som knytter menneskets frihet til offentlige institusjoner - tilbakeviser Møen myten om at en omfattende velferdsstat slik den norske er, ikke kan innebære et aktivt samfunn. Et aktivt samfunn har en betydelig frivillig organisering i det sivile samfunnet, og Møen peker på at dette nettopp fremmes av at vi lever liv der vi til stadighet møter offentlige institusjoner gjennom for eksempel skolen, andre utdanningsinstitusjoner, helsetjenester og kulturinstitusjoner. I den etterfølgende artikkel gir Kristoffer Chelsom Vogt innsikt i hvordan en myte kan implisere en rekke prinsipielle syn og forståelser. Vogt gjør rede for hvordan myten om velferdsavhengighet - myten om at velferd skaper avhengighet av velferdsstaten - bygger på et individualistisk syn på menneskets liv og sosiale relasjoner, en snever forståelse av velferd og 
en feilaktig forståelse av hvordan velferdsstaten fungerer. Sentralt i Vogts argumentasjon står dokumentasjonen av hvor vanskelig det er å snakke om selvstendige, uavhengige liv, og hvordan et livsløpsperspektiv er egnet til å vise menneskers 'sammenvevde liv' i et livsløp og forholdet til en historisk-institusjonell kontekst.

De tre siste artikler behandler myten om eldrebølgen, myten om alenemødrene og myten om fengselspinen. Karen Christensen diskuterer en myte som har tatt form av en metafor: eldrebølgen. Christensen redegjør for hvordan denne metaforen oppstår ut av en sosialpolitisk diskusjon i mellomkrigstiden om endringer i befolkningsutviklingen henimot flere eldre og små fødselskull, men deretter tar en helt annen retning, der stigmatisering av alderdom står sentralt. Knyttet til bildet av bølgen som kommer - uønsket altså - og deretter det kraftige bølgenedslaget, viser Christensen for det første at 'bølgen' ikke kan kan oppfattes som uønsket. Hun peker her på at samfunnet aktivt har skapt betingelser for stadig høyere levealder og presentert dette som et suksessmål for forbedrede leverstandarder og kontroll med sykdommer. For det andre dokumenterer hun hvordan det 'kraftige' bølgenedslaget gir et ufullstendig bilde av en utvikling i omsorgstjenestene, der eldre sammenliknet med yngre (under pensjonsalder) over tid får mindre hjelp og slik taper i 'konkurransen' om tjenestene. I artikkelen etter Christensen presenterer Liv Johanne Syltevik myten om alenemødrene. Sylteviks artikkel gir innsikt i hvordan myter kan være 'virksomme', det vil si at de kan få en aktiv innflytelse på politikken på et område; dette gjelder her stønader for alenemødre. Med utgangspunkt i debatten som Carl I. Hagen startet, da han i 1989 anklaget alenemødre for å være 'latsabber, unnalurere' m.m., argumenterer Syltevik for at det ble utviklet en myte om at alenemødre utnytter velferdsstaten gjennom stønader. Syltevik peker på at norske alenemødre senere avløses av innvandrerkvinner som anklages for å skille seg 'norsk', men ikke 'muslimsk', og slik også utnytter velferdsstaten. Ved hjelp av fakta om utviklingen i stønadsordninger samt de økte krav for å motta stønadsordninger, tilbakeviser Syltevik myten om 'unnalurende' alenemødre. Men hun redegjør slik også for hvor stor innflytelse myter kan få på politikken. Hennes artikkel er slik en påminning om aldri å undervurdere mytenes ideologiske makt. 
I den siste artikkel redegjør Ingrid Rindal Lundeberg for en myte som kan sies i mindre grad å ha vært fremme i mediene. Likevel er det snakk om en forestilling som er rotfestet $i$ allmenne ideer, her om betydningen av fengselsstraff. Lundeberg presenterer myten om fengselspinen, det vil si forestillingen om at et opphold i fengsel handler om en fortjent straff og slik er og skal være pinefull. Med utgangspunkt i en større empirisk studie om livet før, under og etter soning av straff i norske fengsler gir Lundeberg innblikk i på hvilken måte dette bildet er ufullstendig. Ufullstendigheten handler her om, at det finnes tiltak og ordninger i norske fengsler i dag - basert på ideer om rehabilitering, brukermedvirkning og ansvarliggjøring - som kan gjøre soningstiden meningsfull og dessuten bidra til konstruktive endringer i livet etter soningen. Lundebergs artikkel demonstrerer, hvordan en myte kan brukes til å styrke en samfunnsnorm om at kriminalitet er uakseptabelt og derfor skal slås hårdt ned på med straff som er pinefull. Artikkelen er en kilde til refleksjon over samfunnets straffenorm.

Artikkelforfatterne har alle - og de fleste er fortsatt - deltakere i et forskningsprofilområde ved Sosiologisk institutt, Universitetet i Bergen, som kalles 'Velferd, ulikhet og livsløp' (VUL). Det er i dette forumet ideen om og motivasjonen for å lage en samling av velferdsmyter som gjensidig kan opplyse hverandre, oppsto.

Selv om artiklene er skrevet av sosiologer som alle anvender samfunnsvitenskapelig forskning og/eller samfunnsvitenskapelige perspektiver, er dette en bok som er skrevet inn i en bred offentlig debatt og slik også rettet mot et bredt publikum. Diskusjonene henvender seg til alle med ønske om å få mer innsikt i og reflektere over myter om velferdsstaten - studenter som studerer samfunnsfag generelt eller velferdssosiologi spesielt, forskere med interesse for velferd og samfunn, arbeidstakere innenfor og utenfor velferdsstatens yrker, frivillige i lokalsamfunn, mottakere av velferdstjenester/-trygder, debattanter og allment interesserte.

Takk til de andre medlemmene av VUL-gruppen ved Sosiologisk institutt samt professor emerita Kari Wærness for å ha lest og kommentert flere av artiklene underveis i prosessen. Takk også til Bente Blanche Nicolaysen for hjelp i en siste fase med referansesystemer og engelsk 
språk. Vi takker Universitetet i Bergen for å ha finansiert vår Open Access-bok, og endelig retter vi en stor takk til Marte Ericsson Ryste ved Cappelen Damm Akademisk som umiddelbart fattet interesse og engasjement for vårt velferdsmyteprosjekt og hjalp oss med å realisere ideen om en mytebok.

Bergen, oktober 2018 Karen Christensen og Liv Johanne Syltevik 



\title{
ARTIKKEL 1
}

\section{Myten om velferdsstaten}

\author{
Hans-Tore Hansen, professor, Universitetet i Bergen, \\ Sosiologisk institutt
}

\section{Abstract}

Title: The Myth of the Welfare State. Summary: This article takes a closer look at the legacy and relevancy of The Myth of the Welfare State. The anthology was received with great attention and debate when its first editions appeared in the early 1970s. The article examines the anthology's individual contributions (primarily from the 1973 edition), placing them within both an historical context and more contemporary discussions about "public sociology". The article goes on to assess the anthology's contributions against the backdrop of one main guiding question: do the anthology's critiques of welfare myths still have relevancy for current welfare research and contemporary discussions about the welfare state? Lower levels of poverty during the 1970s (together with little recognition of poverty as a problem at that time compared to today) weakens somewhat, the article argues, the anthology's relevance to our contemporary understanding of poverty in Norway. Poverty continues, however, to exist as a social problem today, although Norway's poverty levels are low compared to many other countries in the world. The article identifies common themes in contemporary Norwegian poverty debates and topics raised in the anthology in the early 1970s. The article concludes that many of the topics and discussions raised in The Myth of the Welfare State are still visible in, and relevant to, contemporary discussions on the nature of the welfare state.

Keywords: the myth of the welfare state, the sociology of the welfare state, the Norwegian welfare state, public sociology, poverty

\section{Innledning}

I 1970 ga Pax forlag ut antologien Myten om velferdsstaten. Boken hadde sitt utspring i et nummer av tidsskriftet Kontrast som kom ut i 1967, og som raskt ble utsolgt. ${ }^{1}$ Det samme skjedde også med boken som kom ut i 1970, og en revidert utgave som kom ut i 1973. Lars Gunnar Lingås,

Sitering av denne artikkelen: Hansen, H-T. (2018). Myten om velferdsstaten. I K. Christensen \& L.J. Syltevik (Red.), Myter om velferd og velferdsstaten (s. 15-37). Oslo: Cappelen Damm Akademisk. https://doi.org/10.23865/noasp.47.ch1

Lisens: CC BY-NC 4.0 
som var redaktør for dette prosjektet, redigerte senere to nye bøker om det samme tema: Myten om velferdsstaten - 20 år etter (1989) og Myten om velferdsstaten - 25 år etter (1995). På baksiden av den siste boken står følgende:

Første gang Pax utga en antologi om norsk sosialpolitikk med tittelen Myten om velferdsstaten, var den en bombe i den sosialpolitiske debatten. For første gang etter krigen var det noen som uttrykte opprørske tanker i forhold til den veletablerte sosialpolitikken. I 1989 ga nesten de samme bidragsyterne sine perspektiver til kjenne - 20 år etter. De var da blitt veletablerte fagfolk, men fortsatt kritiske. [...] Velferdsstatens verdigrunnlag og utviklingstrekk er ikke lenger gjenstand for allmenn enighet» (Lingås, 1995, baksidetekst).

Den store interessen som det var rundt dette bokprosjektet, vekker nysgjerrighet. Hva handler myten om velferdsstaten om, og er de opprørske tankene fortsatt relevante - nå - 50 år etter at prosjektet startet og det institusjonelle rammeverket rundt den moderne velferdsstaten - symbolsk markert med innføringen av folketrygden i 1967 - kom på plass? Et tilbakeblikk på dette prosjektet er også interessant med tanke på de store samfunnsmessige endringer som har funnet sted i denne perioden. Stikkordsmessig har Norge blitt en oljenasjon; utdanningsnivået, yrkesaktiviteten (særlig blant kvinner) og innvandringen har økt; det har vært en rivende teknologisk utvikling med den nye datateknologien, Internett og et økt mediemangfold; og - velferdsstaten har vokst og ekspandert kraftig. Myten om velferdsstaten er også av sosiologisk interesse. 1970 er blitt omtalt som det året da sosiologien i Norge overtok rollen som «poetokratiet» tidligere hadde hatt som premissleverandør for samfunnsdebattene (Thue, 1997, 1998), ${ }^{2}$ og 1970-tallet var tiåret da den internasjonalt dominerende Parsons-inspirerte sosiologien i økende grad ble utfordret fra marxistisk og feministisk hold. ${ }^{3}$ Boken er også av sosiologisk interesse ved at den framstår som et godt eksempel på det som i senere år har blitt omtalt som "public sociology», eller offentlig sosiologi. Dette er en form for sosiologi som har dype røtter i faget, og som handler om å bringe inn og engasjere et ikke-akademisk publikum i sosiologien. Offentlig sosiologi fikk for alvor stor oppmerksomhet med Michael Burawoys tale som ny president i den amerikanske sosiologiforeningen, der han oppfordret 
sosiologer til i større grad å engasjere seg i offentlige debatter (Burawoy, 2004a, 2004b, 2005).

I denne artikkelen vil det bli sett nærmere på «Myten om velferdsstaten». Med utgangspunkt i boken som kom ut i 1973, som er den mest omfattende, og som faglig sett også representerer et større nybrottsarbeid enn de to påfølgende mytebøkene, vil det bli stilt spørsmål ved hva boken handler om, og om det gir mening å hevde at det i dag finnes en myte om velferdsstaten. ${ }^{4}$

\section{Hva handler «myten om velferdsstaten» om?}

Svaret på dette spørsmålet er at dette ikke fremgår klart av de tre bøkene. Med unntak av Steinar Stjernø (1989), som i boken Myten om velferdsstaten - 20 år etter er opptatt av å tilbakevise ulike myter om fattigdommen, brukes ikke mytebegrepet i disse bøkene. Det kan likevel argumenteres for at myten som forskerne er opptatt av å avvise, er at vi har en velfungerende velferdsstat som fungerer likt for alle samfunnsborgere. Som statsviteren Knut Dahl Jacobsen skriver om i kapittelet «Politisk fattigdom», er påstanden at velferdsstandsutviklingen og den sosiale omsorgen først og fremst har kommet de funksjonsdyktige til gode: «Slik vi blant annet finner det uttrykt i Folketrygden, hvor den som har mest også skal få meste: til enhver etter hans gasje» (Dahl Jacobsen, 1973, s. 175). Selv om Dahl Jacobsen erkjenner at situasjonen er blitt mer tilfredsstillende enn før, stiller han seg likevel sterkt kritisk til å bruke begrepet «velferdsstat» fordi han mener at dette begrepet gir inntrykk av at alle er blitt frigjort fra nød og fattigdom, noe han omtaler som «en grov fortegning». De svake i samfunnet er ifølge Dahl Jacobsen blitt sveket, og forklaringen på dette ligger $i$ at «systemet forutsetter at klientene gjør seg kjent med de offentlige tiltak som gjelder dem selv, at de gjør bruk av de offentlige godene som stilles til disposisjon og kan beskytte seg mot offentlige onder, i den grad de har rett til det» (s. 179). Grunnen til at det er så lite oppmerksomhet omkring fattigdomsproblemet i sosialpolitikken, er ifølge Dahl Jacobsen at de som er dårligst stilt, ikke tar i bruk sin stemme. Og siden politikerne er opptatt av stemmer, så får de fattige heller ingen politisk oppmerksomhet eller innflytelse. 
Oppfatningen til Dahl Jacobsen om at «Det er ingen søndagsstillhet i sosialsektoren ... Men det er heller ingen utbredt følelse av krise» (s. 177) deles også av andre forfattere i boken. Et eksempel finnes i innledningskapittelet, der historikeren Hans Fredrik Dahl skriver:

De prosentene av Norges befolkning som ikke kan følge med i det normale samfunnsliv (les: produksjonslivet), yter samfunnet en tjeneste ved å holde seg usynlige. Det vil si: De holder seg i passiv avstand fra produktive aktiviteter og mottar trygd eller støtte for det (s. 14).

Dahl og Dahl Jacobsen er begge kritiske til de store sosiale skjevhetene som de mener preger det norske samfunnet, men de har ulike problemforståelser og løsningsforslag. Forskjellen mellom dem gjenspeiler seg også i andre bidrag i boken. Dahl Jacobsen og andre som kan regnes som å tilhøre «klientifiseringsperspektivet», for å bruke et begrep som blir brukt i boken, er opptatt av at velferdsstaten svikter de som er mest svakstilte i samfunnet, og at velferdsstaten er blitt et prosjekt for de bedrestilte. I kontrast til dette retter kritikken til Dahl og de andre som tilhører «utstøtingsperspektivet», seg ikke mot velferdsstaten og dens profesjoner, men mot det økonomiske (les: kapitalistiske) systemet, som de mener er en kilde til de sosiale problemene som velferdsstaten forsøker å håndtere. Tilhengerne av klientifiseringsperspektivet er ikke tydelig på om problemene lar seg løse, men de er tydelig på at situasjonen kan bli bedre dersom velferdsstaten organiseres og innrettes annerledes. Disse forskjellene gjenspeiler seg også i hvilke sosiale grupper forfatterne er mest opptatt av. Utstøtingsforskerne er mest opptatt av eldre mannlige arbeidstakere, mens de som anlegger et klientifiseringsperspektiv, er opptatt av grupper som har problemer som ikke like lett kan tilbakeføres til arbeidslivet, slik som personer med rus- eller helseproblemer, psykisk utviklingshemmede, samer og enkelte grupper av kvinner. Felles for forfatterne er at de har et tydelig politisk engasjement for at staten skal ta et større ansvar for sårbare og ressurssvake grupper. Det er ingen som inntar en posisjon som man finner hos amerikanske forskere som Charles Murray og Lawrence M. Mead, som har argumentert for at borgerne og samfunnet vil være bedre stilt uten en omfattende velferdsstat. Og i motsetning til den nå dominerende økonomiske insentivtenkningen er det ingen som 
argumenterer for at det er behov for kutt eller nedskjæringer i velferdsgoder. Underforbruk blir av flere trukket fram som å være et større problem enn misbruk. En annen sentral debatt, som har lange røtter innenfor både sosialpolitikk og velferds- og sosialforskning, handler om hvilke grupper i samfunnet som skal prioriteres, og i hvilken grad tildeling av goder skal skje på bakgrunn av en behovsprøving eller ikke. ${ }^{5}$ Kritikken som flere av forfatterne i boken retter mot at velferdsstaten er blitt rigget slik at den først og fremst kommer middelklassen og de ressurssterke til gode, kan tolkes som et argument for at ressurser i større grad bør omprioriteres og i større grad gå til de svakeste i samfunnet. Kritikken som rettes mot velferdsbyråkratier, tilsier at forskerne vil være kritiske til at goder og ytelser fra velferdsstaten i større grad bør behovsprøves slik som vi i dag kjenner igjen i diskusjoner omkring barnetrygden og fattigdom blant barn.

\section{Fattigdomsproblemet}

Fattigdom er et sentralt tema i boken. Dette er ikke overraskende, gitt at bekjempelse av fattigdom var et av de viktigste motivene for å etablere de moderne velferdsstatene, og nøden var åpenbar og synlig på den tiden boken kom ut. Det etablerte seg både her til lands og i andre land etter hvert en oppfatning om at fattigdom var et problem som tilhørte fortiden. Et kjent sitat som kan tas med i denne sammenheng, kom fra daværende statsminister Odvar Nordli, som i 1979 uttalte at det var «for første gang i dette lands historie, og for de andre nordiske land, at vi kan bestemt si at fattigdom og sosial nød er blitt utryddet» (sitert i Stjernø, 1985, s. 13). En som tidlig utfordret denne oppfatningen, var den britiske sosiologen Peter Townsend, som pekte på at fattigdom ikke bare dreier seg om materiell nød, men at det også handler om mangel på tilstrekkelige ressurser til å leve et verdig liv (se f.eks. Townsend, 1977). Townsends tanker var velkjent for Vilhelm Aubert (1973), som i kapittelet «Fattigdom i Norge» forsøker å kartlegge inntektsfattigdommen i Norge ved hjelp av tall fra skatteligningen fra 1962. I tråd med en relativ og inntektsbasert forståelse av fattigdom undersøker han hvor mange som har en årsinntekt under 4000 kroner, og hvor mange som har en årsinntekt mellom 4000 og 8000 kroner. Uten at han har data som kunne gitt ham empirisk belegg for dette i sine 
analyser, mener Aubert at det er grunn til å anta at fattigdommen vil være mest utbredt på bygder der det finnes få ressurser. Skogsarbeidere som bor på slike steder, vil ifølge Aubert være særlig utsatt for fattigdom. Siden eldre personer vil være beskyttet av alderspensjonen, mener Aubert at hushold der forsørgerne er unge, vil være mer utsatt for fattigdom enn hushold med eldre personer. Aubert peker på at det også finnes mye fattigdom blant visse grupper kvinner, og da særlig blant ugifte kvinner, enslige mødre og hushjelper. I 1965 var det om lag 100 ooo uførepensjonister i Norge, og dette er ifølge Aubert den gruppen som trolig er mest rammet av fattigdom. Fattigdommen er ifølge Aubert trolig svært omfattende i denne gruppen, og spesielt vil dette være tilfelle for de som lever i byene, siden de har høyere levekostnader enn de som bor på landsbygden. Litt overraskende ut fra hva som er situasjonen i forskningen i dag, viser Aubert til at i motsetning til den omfattende forskningen som finnes om alkoholisme og kriminalitet, finnes det lite forskning om situasjonen til uførepensjonistene. Den gruppen som Aubert leverer de mest inngående analysene av, er samene. ${ }^{6}$ Anslag som Aubert viser til, tilsier at det var om lag 20000 samer i Norge på 1960-tallet, men som følge av at det er mange som ikke lever i tråd med den tradisjonelle språk- og næringskulturen, er det ifølge Aubert grunn til å tro at dette anslaget er altfor lavt. Med referanse til den høye barnedødeligheten omtaler han situasjonen til samene som «U-landsproblemet innenfor vårt eget samfunn» (Aubert, 1973, s. 24-25), og han kritiserer politikken på dette området for å være feilslått og ligne på rasediskriminering. Aubert stiller seg sterkt kritisk til at fattigdommen blant samene blir forklart med «dovenskap eller en mangel på interesse for livets goder begrunnet i religiøs innstilling» (s. 27). Aubert peker på at denne oppfatningen om at fattigdommen blant samene er kulturelt betinget, og at det dreier seg om holdninger og atferdsmønstre som går i arv og blir formidlet fra generasjon til generasjon, ligner på forklaringene som Oscar Lewis framsatte i sine velkjente studier fra Mexico om fattigdommens kultur. Aubert er skeptisk til Lewis og kulturelle forklaringer på fattigdom, og mener at en mer nærliggende forklaring på samenes situasjon er at de har vært henvist til å slå seg til i områder med dårlig naturgrunnlag, og at de har slitt med problemer som språkvansker, mangelfull utdanning og geografisk isolasjon, 
samt at det har vært en utbredt mistillit mellom majoritets- og minoritetsbefolkningen. At velferdsstaten ikke har maktet å gjøre noe med samenes situasjon, skyldes ifølge Aubert at funksjonsspredning i forvaltningen har medført at ingen har hatt et særskilt ansvar for den samiske delen av befolkningen.? En annen utfordring som han tar opp, er at den samiske befolkningen ofte utgjør en minoritet innenfor en befolkning som er fattige, og dette gjør at det vil være vanskelig å skille mellom fattigdomsproblemet og minoritetsproblemet. Aubert er bekymret for at en kamp mot fattigdomsproblemet lett kan bli en kamp mot de som blir rammet av fattigdom, og han avslutter slik: «En rasjonell holdning og en effektiv politikk må bygge på kunnskap om levevilkårene blant dem som er falt igjennom velferdsstatens brannseil» (s. 31). Kort sagt, for Aubert handler mytene om velferdsstaten om at vi ikke har erkjent at vi har et omfattende fattigdomsproblem i det norske samfunnet, og at fattigdommen som finnes, blir sett på som å være kulturelt betinget. Det er ikke mulig innenfor rammene av denne artikkelen å gå videre inn på dagens debatter, men det er åpenbart at diskusjonene til Aubert har likhetstrekk med nåtidige debatter om innvandring. Interessant nok blir også Oscar Lewis' studier, som Aubert stilte seg kritisk til, fortsatt drøftet innenfor dagens fattigdomsforskning.

\section{Svikten i hjelpeapparatet}

Et sentralt tema i Myten om velferdsstaten er at hjelpeapparatet svikter i å følge opp de som står svakest i samfunnet. ${ }^{8}$ Dahl Jacobsens og Auberts bidrag er to eksempler på forskere som tar opp denne tematikken. Guri Grøsland (1973), som var leder for Norsk Forbund for Psykisk Utviklingshemmede i perioden 1979-1981, går grundigere inn på denne tematikken i sin diskusjon av situasjonen til psykisk utviklingshemmede barn. Grøsland starter sitt kapittel med å vise til en reportasje om Klæbu pleiehjem - «Statens største hjem for åndssvake» - der det blir reist sterk kritikk mot den mangelfulle hjelpen som blir tilbudt denne gruppen. Hun er kritisk til oppfatningen om at problemet innenfor «åndsvakeomsorgen» handler om barnas lave IQ og mangel på plasser. Utgangspunktet bør ifølge henne heller være at vi bør se på hvilke ressurser og mulighetene 
disse barna har, og barnas behov bør dessuten også betraktes som å være normale. Samfunnet bør støtte og supplere foreldrene, og ikke la institusjonene overta alt ansvaret slik som tilfellet er.

Vi må se mennesket med en psykisk utviklingshemning som en del av sin familie og som en del av samfunnet. Vi må anerkjenne de psykisk utviklingshemmede som medborgere med samme alminnelige borgerrettigheter og menneskerettigheter som enhver annen medborger. Samfunnets servicetilbud må innrettes med sikte på å ivareta så vel de alminnelige rettigheter som de spesielle behov hos psykisk utviklingshemmede (Grøsland, 1973, s. 127).

Njål Petter Svensson argumenterer i kapittelet «Velferdssamfunn eller klassesamfunn?» for at det er «de veletablerte, - de yrkesaktive og funksjonsdyktige som i første rekke drar nytte av velstandsøkningen ... ingen sulter lenger, men der stopper også adgangen til velferd for mange» (1979, s. 181). Svensson peker på at den offentlige innsatsen er todelt ved at de som kommer inn under lov om folketrygd, har langt bedre vilkår enn de som kommer inn under lov om sosial omsorg, som oppstod som en revidert utgave av den gamle forsorgs- og fattigdomsloven. Svensson er spesielt kritisk til behandlingen som de som har opparbeidet seg et vanry ved alkoholmisbruk, kriminalitet eller annen form for uakseptabel atferd eller sykdom, blir utsatt for ved sosialkontorene. Måten disse blir møtt på ved sosialkontorene, er ifølge Svensson preget av tilfeldigheter, moralisme og diskriminering. Han viser til at det ikke er sosialarbeiderne, men folkevalgte nemnder som avgjør hvorvidt klienter skal få den hjelpen de ber om. Svensson, som er utdannet sosionom, anklager sosialarbeiderne for å ha blitt «et redskap til å opprettholde de rådende klasseskiller og ulikheter ...». Sosialarbeiderne oppfatter ifølge Svensson de rådende samfunnsforholdene som uforanderlige og ser det som sin oppgave å forsøke å tilpasse individene til de rådene samfunnsforholdene. Sosionomene er ifølge Svensson «overdrevet individorienterte» og preget av en «forvirrende og noe ureflektert verdinøytralitet».

Man kan glemme sin Freud og sine fine motivasjonsteknikker i det øyeblikk man står overfor det problem å tilpasse en 50 år gammel mann til arbeidslivet når det ikke finnes noen arbeidsgiver som vi gi mannen arbeid. Når en familie på to voksen og tre barn må bo på et lite rom og uten kjøkken i en 
saneringsmoden bygård uten tilfredsstillende fyringsmuligheter hvor vanntilførelsen svikter i vinterhalvåret - hvor utedoen er rast samme og avtredene må gjøres på nærmeste T-banestasjon (Svensson, 1973, s. 189).

Svensson retter hard kritikk mot sosialarbeiderne, men han har tro på at en bedre utdanning av sosialarbeiderne etter hvert vil føre til endringer.

Yngvar Løchen (1973) starter sitt kapittel «Velferdsstatens handicap» med følgende setning: «Velferdsstaten bygger på det grunnsynet at den enkeltes nød ikke bare er et individuelt, men også et sosialt problem» (s. 33). Løchen viser til sine egne og andres studier, som har vist at det finnes en avstand eller et spenn mellom idealer og realiteter. Dette skyldes at det i sosialpolitikken blir satt opp svært idealistiske målsettinger, og som følge av at partiene stadig forsøker å overby hverandre uten at de sikrer at det finnes nødvendige ressurser og fagfolk til følge opp målsettingene, blir spennet mellom idealer og realiteter stadig større. Løchen er også kritisk til at i motsetning til tidligere tider er det nå byråkratiet og ikke Stortinget som ivaretar den systematiske og faglige tenkningen innenfor sosialpolitikken.

\section{Utstøting fra arbeidslivet}

Jon Eivind Kolberg (1973) er i kapittelet «Det klientskapende systemet» kritisk til den rådende oppfatningen om at velferdsstatens hovedproblem handler om at det tungrodde velferdsbyråkratiet ikke klarer å fange opp nøden i samfunnet. Fokuset må ifølge Kolberg (1973) heller rettes mot de store strukturrasjonaliseringene som skjer i næringslivet, og som skaper de store sosiale problemene: «... mekanisering og innføring av stordriftsformer innenfor hele økonomien reduserer småkårsfolks strategiske sosialpolitiske forhandlingsposisjon vis-à-vis de store korporasjonene som i stadig større utstrekning tilriver seg monopol på å skape jobber» (s. 142). Han er også kritisk til oppfatningen om at utviklingen med en økende andel trygdede i befolkningen skyldes normen om at lønnsarbeid er blitt svekket. Trygd og pensjonering er ifølge Kolberg ikke et resultat av manglende arbeidsmotivasjon, men av dårlige arbeidsvilkår. Han viser i denne sammenheng til den svenske bedriftslegen Mindus, som hevder at folks aspirasjonsnivå har en tendens til å bli redusert, slik at objektivt sett 
utilfredsstillende situasjoner blir opplevd som tilfredsstillende. En konsekvens av slike resignasjonsmekanismer er ifølge Mindus at motstandskraften mot psykiske og fysiske pressituasjoner blir redusert. Selv om Kolberg ikke skriver seg inn i en marxistisk tradisjon, har diskusjonen hans klare likhetstrekk med en marxistisk samfunnsforståelse. I et marxistisk begrepsverk handler disse problemene om fremmedgjøring og mangel på kontroll over arbeidsprosessene. Kolbergs beskrivelse av sentraliseringsprosessene og mulighetene til selvforsørgelse som forsvinner, har klare likhetstrekk med den opprinnelige akkumulasjon, slik Marx beskriver den. I motsetning til marxister i sin samtid inntar Kolberg en litt resignert posisjon når han reiser spørsmålet om det er mulig å snu utviklingen:

Med fare for å bli kalt for uansvarlig har jeg lyst til å si en ting til: Kanskje kunne det være Norges store sosialpolitiske ${ }^{9}$ oppgave å si nei - vi hopper av lasset: det koster oss menneskelig for mye å følge med (s. 147).

Økonomen Per Nestor (1973) er i sitt kapittel kritisk til flere trekk som han mener gjør seg gjeldende i det kapitalistiske økonomiske systemet: Det skjer en konsentrasjon av realkapitalen på stadig færre hender, produksjonen dreier seg i stor grad om å frembringe goder som dekker mindre nødvendige behov, og det mangler instanser som ivaretar mer overordnede hensyn. Som mer konkrete eksempler på uheldige forhold viser han til: (1) luftforurensningen i Los Angeles, (2) at for liten andel av de produktive ressursene i samfunnet blir stilt til rådighet for offentlige institusjoner som dekker fundamentale menneskelige behov, og (3) at etablering og nedleggelse av bedrifter skjer uten at de som blir rammet, får et ord med i laget. Han er også kritisk til fagbevegelsen, som han mener har vært for mye opptatt av økt produktivitet og for lite opptatt av fordeling av makt og ressurser. Nestor er også opptatt av kvinners stilling i samfunnet, og han skriver at «rollefordelingen er en fundamental faktor i det privatkapitalistiske samfunnet. Det gir nemlig de største muligheter for manipulasjon med mennesket både som produksjonsfaktor og som forbruker» (s. 159). Han viser til at menn er blitt tildelt rollen som forsørger, noe som gir dem «en viss kompensasjon for den maktesløsheten som vanligvis karakteriserer hans situasjon på arbeidsplassen», 
og at «motstykket til denne maskuline makt er den feminine avmakt, som gjør husmødre til et lett bytte for markedsførerne» (s. 159). Menns manglende innsats i husarbeidet forklarer han med lange arbeidsdager og lange reiser til jobben. Nestor ser den kjønnsbestemte arbeidsdelingen som å være i det kapitalistiske systemets interesse, og han hevder at systemet er dysfunksjonelt ved at det skjer en behovsforskyving der grunnleggende behov ikke blir dekket. Nester peker på at det er en betydelig skjult arbeidsløshet blant kvinner, og da særlig blant de som er over 40 år, og han mener at de sinnslidelsene som finnes blant kvinner, kan tilskrives den skjulte arbeidsledigheten de er utsatt for.

Rolf Otto Hanoa (1973) starter sitt kapittel med å slå fast at: «Norge er et klassesamfunn» (s. 80). Som sosialmedisiner er Hanoa opptatt av klassesamfunnets helsemessige effekter. Hanoa viser til at personer med lav lønn og som har yrker med lav status, er mer utsatt for å pådra seg sykdommer og helseskader enn andre, og helsesektoren er ifølge Hanoa dessuten innrettet slik at hvilken hjelp vi får, vil være betinget av hvilken klasseposisjon vi tilhører. Mer konkret viser han til at det finnes en rekke sykdomstilstander som er klassebetinget, slik som slitasjeskader, alkoholisme og nevroser som ikke blir akseptert av helse- og sosialvesenet. For Hanoa (1973) handler dette om et grunnleggende premiss i folketrygden:

«De som har mye, skal få mye hjelp, og de som på forhånd har lite, skal få tilsvarende mindre når de trenger hjelp. Og i tillegg til dette er det et allmenngyldig poeng, at de som ikke passer inn i systemet vårt, ikke skal få noen hjelp av oss heller» (s. 89).

Hanoa viser til at de eneste ytelsene som ikke følger premisset om at de som har mye, også skal få mye, er barnetrygden og morstrygden til ugifte. For Hanoa er situasjonen den at helse i stor grad handler om klasseforhold, og siden helsevesenet ikke anerkjenner en rekke sykdomstilstander som er klassemessig bestemt, bidrar det således til at problemene blir forsterket. Hvis en skal tolke Hanoa inn i et myteperspektiv, er det nærliggende å hevde at det er to myter han er ute etter å avlive. Den ene er at helseproblemer ikke handler om klasseforhold. Den andre er at velferdsstaten fungerer likt for alle. 


\section{Diskusjon}

Som nevnt innledningsvis kan spesielt den første utgaven av Myten om Velferdsstaten ses på som et eksempel på det som i de senere år har fått betegnelsen «Public Sociology». I sin diskusjon av denne formen for sosiologi skiller Burawoy mellom «tradisjonell» og «organisk» offentlig sosiologi. Den første retningen handler om forskningsformidling, og dette omtaler Burawoy som å være «bare snakk». I kontrast er organisk offentlig sosiologi opptatt av at sosiologer må jobbe sammen med samfunnet rundt seg for å få til sosiale endringer. ${ }^{10}$ Offentlig sosiologi har i utgangspunktet ikke tilknytning til noen bestemt form for metode, teori eller politiske verdier, men Burawoys visjon handler om demokratisk sosialisme og om å styrke sivilsamfunnets institusjoner mot det presset de blir utsatt for fra stats- og markedskreftene. ${ }^{11}$ Det politiske engasjementet som kommer til syne i den første boken, har klare likhetstrekk med Burawoys politiske prosjekt ved at det rettes kritikk mot markedet («utstøtingsperspektivet») og staten («klientifiseringsperspektivet»), men de norske forfatterne tilkjennegir nok en mer positiv grunnholdning til staten enn det Burawoy gjør. For å spinne på et velkjent uttrykk fra Helga Marie Hernes, så handler nok dette om at de norske forfatterne forholder seg til (løfter om) en ny og mer menneskevennlig velferdsstat. Men selv om den første boken i prosjektet har klare ideologiske likhetstrekk med Burawoys «organisk offentlig sosiologi», skiller den seg klart fra det forskningsidealet Burawoy setter opp. Det dreier seg ikke om et prosjekt der forskerne inngår i en likeverdig allianse med «folket». Det er forskerne som har definert problemstillingene, som har valgt metodene, og som leverer analysene og kommer med politiske råd og innspill. Forfatterne inntar posisjonen som eksperter som forklarer og opplyser allmennheten om hvordan ting henger sammen: Velferdsstaten er blitt et prosjekt for de bedrestilte i samfunnet, vi har fortsatt et omfattende fattigdomsproblem, velferdsbyråkratiet behandler de svakerestilte i samfunnet på en nedverdigende måte, og vi lever i et kapitalistisk samfunn som skaper de sosiale problemene som velferdsstaten forsøker å håndtere. De politiske markeringene som en finner mange eksempler på i den første boken, er mindre tydelige i de to påfølgende mytebøkene. Bruker en begrepene til Burawoy, 
kan en således si at bokprosjektet endret karakter fra å ha trekk av å være organisk offentlig sosiologi til å bli «bare snakk» (se Møens artikkel for ytterligere innsikt $i$ et normativt standpunkt i diskusjonen om velferdsstaten). Gitt at flere av forfatterne som er med i 1973-boken, også er med i boken som ble utgitt i 1995, kan en forklaring på dette være at forfatterne har endret - om enn ikke politiske standpunkter - så i alle fall oppfatninger om i hvilken grad forskere skal tilkjennegi klare politiske standpunkter. ${ }^{12}$ En annen forklaring kan være at dette handler om større ideologiske og samfunnsmessige endringer.

En som har jobbet mye med dette er historikeren Fredrik Thue (1998), som beskriver 1960-årene som tiåret da velferdsstaten ekspanderte kraftig, samtidig som gjenreisningsperiodens vekst- og velferdsideologi ble utfordret av studentopprør og ungdomskultur (s. 285, jf. også Mjøset, 1991). ${ }^{13}$ Thue viser til at det rundt 1970 vokste fram en ny sosialopplysningsideologi der det ble utviklet nye kunnskapspraksiser og faglitterære former, og han viser til at den tidligere etterkrigstidens samfunnsforskning vokste frem som en direkte reaksjon mot den humanistiske fagtradisjonen, der «Samfunnsforskningen ble lansert som et nytt dannelsesprosjekt for det moderne sekulariserte samfunnet» (Thue, 1998, s. 286). Ifølge Thue var det ingen tilfeldighet at samfunnsforskningens seier over poetokratiet ble forkynt i 1970. Thue legger stor vekt på den posisjonen Pax forlag hadde når det gjelder å sette ting på den politiske dagsorden (jf. også Dahl, 2012: Helsvig, 2014). Forlaget, som sprang ut av avisen Orientering, hadde nære politiske og intellektuelle bånd til forskere, og utga mange bøker med norske samfunnsforskere og internasjonalt kjente navn som Freud, Jung, Erik Fromm og C. Wright Mills. Tidsskriftet Kontrast kom også ut på denne tiden, og større og mer etablerte forlag fulgte opp linjen til Pax med å utgi billige debattbøker. Rammene for denne artikkelen gir ikke muligheter til å gå nærmere inn på den historiske utviklingen og rammene for de to påfølgende bøkene i prosjektet, men bøkene er som nevnt preget av at forskerne leverer bidrag fra et mer nøytralt faglig ståsted, der publikum nok er akademikere og studenter og ikke allmennheten mer generelt slik tilfellet var for den første myteboken. Det kan for øvrig legges til at dersom en ser på nyere debattbøker, inklusiv de som 
kommer fra de mange nye tenketankene, så har de ofte preg av å være vitenskapelige tekster på det viset at det ofte er med mange tall og referanser til faglitteratur.

Det er opplagt mange ting utenom genrekravene og offentligheten som har endret seg siden Myten om velferdsstaten kom ut første gang. Selv om Aubert, som dagens fattigdomsforskning, i sitt kapittel legger til grunn en relativ forståelse av fattigdom, er det likevel klart at når Aubert og andre forfattere i den første boken drøfter fattigdom, så handler det om nød og elendige boforhold som det finnes lite av i dagens norske samfunn. Hanoa viser for eksempel i sitt kapittel til undersøkelser fra 1960 som viste at $39 \%$ av leilighetene i byer ikke hadde bad og $14 \%$ hadde ikke vannklosett, og han viser også til at det finnes mange boliger som ikke har innlagt vann. For de fleste lesere i dag vil det nok være litt overraskende at situasjonen til samene står så sentralt i en diskusjon av fattigdommen i Norge, og likeledes oppleves det nok som litt merkelig at Grøsland finner det nødvendig å bruke så mye plass på å argumentere mot en problemforståelse som legger til grunn at situasjonen til psykisk utviklingshemmede barn handler om barnas lave IQ. Når Nestor er opptatt av arbeidsdelingen mellom kvinner og menn og den betydelige skjulte arbeidsledigheten blant middelaldrende kvinner, så er det tydelig at han forholder seg til en tid da yrkesaktiviteten blant kvinner var betraktelig lavere enn den er i dag. De kommunalt oppnevnte nemndene som vurderer søknadene om sosialhjelp, som Svensson er kritisk til, finnes ikke lenger, og sosialarbeiderutdanningen er blitt mer profesjonalisert, og det er utarbeidet nasjonale retningslinjer som sørger for at det i dag trolig vil være mindre kommunale variasjoner enn det var da Svensson skrev sitt kapittel. Det er blitt større aksept for at rus og ulike sosiale problemer kan føre til helseproblemer som vil utløse rett til uførepensjon. Et annet eksempel på at ting har endret seg, handler om begrepene som blir brukt. Når Grøsland skriver om «Statens største hjem for åndssvake», er det ikke bare begrepet «åndssvak» som skurrer, det samme gjør også «Statens hjem». Begrepet «klient» blir i boken systematisk brukt om de som mottar hjelp fra eller som blir motarbeidet av - velferdsstaten. Selv om det nok i dag er litt større diskusjoner omkring klientbegrepet (jf. Hansen, Lundberg \& Syltevik, 2003), er det både innenfor forskning og politikk begrepet 
«bruker» som er blitt den gjeldende termen. Enkelte vil se denne endringen i språkbruken som et uttrykk for at staten har blitt mer vennlig og mindre paternalistisk, mens andre heller vil se det som et uttrykk for at den markedsorienterte tenkning og den nye arbeidslinjen med skjerpede arbeidskrav og en ny styringsstrategi og ideologi er blitt mer toneangivende. Sett i ettertid er det ellers påfallende hvor lite oppmerksomhet det er i bøkene om kvinners situasjon. ${ }^{14}$ Aubert viser til hushjelper, ugifte kvinner og enslige mødre som grupper som er mer utsatt for fattigdom enn andre, men noen inngående analyser av hva dette skyldes, leverer han ikke. Interessant nok blir den mest omfattende analysen av kvinners situasjon i bøkene om myten om velferdsstaten levert i den første boken av en mannlig økonom (Nestor). At kvinners situasjon ikke står sentralt i den første boken, er kanskje ikke overraskende, men gitt at kvinneperspektivet på sosialpolitikken var vel etablert da de to siste bøkene kom ut, er det mer overraskende at kvinners situasjon ikke har fått noen større plass i disse bøkene. ${ }^{15}$ Bokprosjektet kan således være et eksempel på usynliggjøring av kvinners situasjon i velferdsstaten, noe blant andre Kari Wærness har påpekt. ${ }^{16}$ Fra et forskningsmessig ståsted er det påfallende hvor mye bedre kvantitative data og metoder vi har tilgjengelig $\mathrm{i}$ dag. Endringene som har skjedd på dette feltet, kommer tydelig fram når en sammenligner Auberts (1973) kapittel om fattigdom med Stjernøs kapittel om det samme tema i Myten om velferdsstaten - 20 år etter (1989). Mens det er vanskelig for Aubert å levere noen presise estimater for hvor omfattende fattigdommen er, og tallene ikke gir ham noen muligheter til å gjennomføre noen analyser av hvem som er mest utsatt for å bli rammet av fattigdom, så bidrar Stjernø med inngående analyser der han tar i bruk ulike typer data for å forsøke å anslå fattigdommens omfang og fordelinger. Enten han studerer inntektsmål eller undersøker en levestandardbasert utarmingsgrense, blir konklusjonen uansett den samme: Om lag $5 \%$ av den norske befolkningen kan regnes som fattige. Interessant nok var det mye debatt om og kritikk mot Stjernøs fattigdomsforskning (se Halvorsen, 2017). Mens reaksjonene på Myten om velferdsstaten var at boken avslørte at virkeligheten var annerledes enn det som ble antatt, var reaksjonene mot Stjernøs fattigdomsanalyser på 1980-tallet at han overdrev fattigdomsproblemets omfang. I dag blir det levert rapporter 
både fra SSB og NAV som dokumenterer mye av det samme som Stjernø gjorde, uten at det vekker noe videre harme og debatt.

Det er mye som har endret seg siden Myten om velferdsstaten kom ut, men det er også mye som er gjenkjennbart og fortsatt høyst aktuelt. Data- og metodeverktøyene er blitt betraktelig bedre i de senere årene, likevel er det analytiske grepet som forskere bruker i dag, ikke så veldig annerledes. Forskere ser fortsatt etter statistiske fordelinger, og de strever fortsatt med å håndtere problemer som at det ikke er lett å ta hensyn til forhold som levekostnader. At det i dag er 200 ooo flere uførepensjonister enn det var i 1965, som er det året Aubert viser til i sitt kapittel, er nærliggende å se på som et tegn på at utstøting fra arbeidslivet fortsatt er en viktig problemstilling. Selv om det har vært mange endringer innenfor velferdssektoren de senere år, med blant annet NAVog HVPU-reformen, er det institusjonelle rammeverket i stor grad uendret med et hybrid system bestående av lov om folketrygd og sosialhjelpsloven som to sentrale bærebjelker. Problemstillinger knyttet til spørsmål om behovsprøving, skjønn og verdighet; og bruk av nemnder, er fortsatt dagsaktuelle tema (jf. også Sylteviks diskusjon av arbeidskravet). For eksempel viser forskningen til Gubrium og Lødemel (2014) at det også i dag er knyttet mye skam og stigma til fattigdom og det å motta sosialhjelp. Kritikken som en finner i bokprosjektet om at velferdsstaten først og fremst er blitt et prosjekt for de bedrestilte i samfunnet, er også noe som toneangivende internasjonale forskere har gitt uttrykk for (se også artiklene til Christensen og Vogt, samt Hills, 2017). Selv om det virker å være rimelig å hevde at historien har gitt Aubert rett når han kritiserer kulturelle forklaringer som årsak til fattigdom blant samene, så gjør kulturelle forklaringer på fattigdom, der det vises til Lewis’ fattigdomsstudier, seg fortsatt gjeldende, men nå gjelder det innvandrere fra ikke-vestlige land. Fattigdomstematikken som etter hvert forsvant fra dette bokprosjektet, og også samfunnsdebatten mer generelt, er igjen kommet opp på dagsordenen. ${ }^{17}$ Alle regjeringer siden Bondeviks første regjering har satt temaet opp på dagsorden og har hatt egne tiltaksplaner mot fattigdom, der søkelyset spesielt har vært rettet mot den økende barnefattigdommen. SSB og Nav publiserer nå jevnlig oversikter over «lavinntektsproblemet». ${ }^{18}$ 


\section{Avslutning}

Gitt at eksistensen av fattigdommen er et kjernepunkt i Myten om velferdsstaten, så kan det reises spørsmål ved om fattigdom som finnes i dagens norske samfunn, gir grunnlag for å hevde at det er belegg for at det i dag finnes en myte om velferdsstaten. Det er kanskje særlig to argumenter som taler mot dette. Det første handler om logikk. Gitt at det i dag er erkjent at fattigdommen, og da ikke minst fattigdommen som finnes blant mange barn, er et av de mest alvorlige sosiale problemene vi står ovenfor, er det vanskelig å hevde at det finnes en myte om at fattigdomsproblemet ikke finnes. Påstander om at det finnes fattigdom, vekket oppmerksomhet da den første myteboken kom, og harme og kritikk da Stjernø (1989) kom med sin forskning, men i dag er det nok mer allment akseptert at det finnes et fattigdomsproblem her til lands. Myter handler om at ting ikke er anerkjent, at noe blir skjøvet under teppet eller ikke blir forstått på rett måte. Det er vanskelig å se at dette er tilfelle for dagens fattigdomssituasjon. Det andre argumentet er at selv om det finnes et fattigdomsproblem i dagens norske samfunn, så kan det reises spørsmål ved om en på dette grunnlag kan hevde at vi ikke har en velferdsstat $\mathrm{i}$ Norge. Det finnes en omfattende forskning som viser at selv om det finnes fattigdom i dagens norske samfunn, som rammer hardt og på mange ulike måter, så er fattigdommens omfang og dybde mindre omfattende i Norge enn ellers i verden. Dette må selvsagt også ses i lys av at vi har en svært omfattende velferdsstat som omfatter en rekke trygde- og pensjonsordninger, et omfattende helse- og utdanningssystem og ulike ordninger som støtter familier generelt og familier i vanskelige situasjoner mer spesielt. Hvis en skal bruke eksistensen av fattigdom som et argument for at det finnes en myte om velferdsstaten, så finnes det vel kanskje ikke noen dårligere eksempel å bruke enn dagens norske samfunn.

En mer aktuell myte i denne sammenhengen er kanskje at fattigdomsproblemet ikke lar seg løse. Alle regjeringer i de to siste tiårene har hatt bekjempelse av fattigdom, og da særlig bekjempelse av barnefattigdommen, som et viktig satsingsområde, men problemet ser ut til å være stadig økende. Det er klart at mye av utfordringene handler om innvandring, men det er også kjent at den manglende indeksregulering av barnetrygden 
er en viktig grunn til at problemet har økt. Når en leser om fattigdom i Myteboken i kontekst av dagens situasjon, er det opplagt at selv om problemet ikke er enkelt, så er det samtidig klart at problemer som fattigdom lar seg håndtere. Et aktuelt sitat i denne sammenheng kan hentes fra Dahl Jacobsens bidrag i boken:

På den ene siden defineres situasjonen som meget tilfredsstillende, sammenlignet med tidligere tider. Vi har maktet å få i stand det vi kaller en velferdsstat. Dette leder fram til en sats om at målene i sosialpolitikken praktisk talt er realisert. På den annen side er vi ikke blinde for at det finnes mangler som kan utbredes. Men vi er nå kommet så langt i sosialpolitisk standard at vi ved utbedring av manglene har plikt til å sette oss høye mål. Bare det beste er godt nok. Dette leder fram til en sats om at målene i sosialpolitikken praktisk talt er urealiserbare (Dahl Jacobsen, 1973, s. 176).

I lys av dette sitatet kan kanskje en annen myte være at velferdsstaten handler om få finne løsninger på bestemte og avgrensede problemer der vi kan se for oss at vi på et eller annet tidspunkt vil komme i mål. Samfunnet er i endring, og velferdsstaten vil således alltid måtte være $\mathrm{i}$ endring. Myten vil således være at en ser på velferdsstaten som et ferdig prosjekt som løser, eller søker å løse gitte problemer.

Selv om den materielle nøden som Aubert, Hanoa, Svensson og andre beskriver i sine kapitler, ikke lenger er like vanlig i den norske befolkningen, har utviklingen med de åpne grensene gjort sitt til at tigging og materiell nød igjen er blitt et synlig trekk ved dagens norske samfunn. Tiggere som kommer fra andre land, utgjør ikke mange personer, men gruppen er likevel synlig, og de setter sitt preg på de fleste norske byer i dag. Sett fra et velferdsstatlig perspektiv er det karakteristisk for denne gruppen at de ikke tilhører målgruppen for den norske velferdsstaten. Anlegger man et simmelsk perspektiv på fattigdom, og ser på fattigdom som noe som handler om historisk og sosialt definerte relasjoner mellom folk, kan det hevdes at det norske samfunnet i dag har fått en ny type fattigdomsproblem som en nok i mindre grad tar fatt i, og som vanskelig lar seg løse innenfor velferdsstatens rammer. At gruppen er blitt utdefinert av velferdsstaten, innebærer ikke at den er blitt utdefinert fra det norske samfunnet i sosial forstand. For sivilsamfunnet og det norske hverdagslivet er 
det opplagt at fattigdom og nød setter sitt preg på det norske samfunnet, og spørsmålene om solidaritet og om verdighet og uverdighet har blitt aktualisert på en ny måte i den norske samfunnsdebatten.

\section{Sluttnoter}

1. Det aktuelle tidsskriftnummeret Kontrast $(1967$, nr. 1) hadde tittelen «Det usynlige Norge». Boken har også et bidrag fra Kontrast (1969, nr. 18) som hadde tittelen «Velferdssamfunnets krise».

2. Bidragsyterne til disse tre bøkene hadde ulik fagbakgrunn. Ser en på alle bøkene samlet, er ni sosiologer, fem økonomer, fem sosionomer, fire statsvitere, to historikere og to psykologer. Går vi nærmere inn på de enkelte forfatterne, blir sosiologifaget mer dominerende enn bidragsyternes utdanning gir inntrykk av. Jon Eivind Kolberg, som var utdannet statsviter, var professor i sosiologi i Tromsø og Bergen, mens Knut Halvorsen, som opprinnelig var utdannet siviløkonom fra $\mathrm{NHH}$, videreutdannet seg og tok doktorgrad i sosiologi. Kolberg og Halvorsen leverte begge i sine tidligere karrierer viktige bidrag til (og senere også kritikk av) utstøtingsteorien, som ofte blir sett på som det viktigste sosiologiske alternativet til den økonomiske insentivtenkningen. Medisineren Hanoas og økonomen Nestors bidrag kan også regnes som å tilhøre utstøtingsperspektivet. Økonomen Schreiner er en mer typisk økonom ved at han er opptatt av statsfinansene. Det er med to historikere i den første boken, men de leverer ikke noen historiske analyser av velferdsstaten. Hans Fredrik Dahl skrev forordet til boken fra 1973 og har levert et bidrag som det er rimelig å regne som en del av utstøtingsperspektivet. Harald Berntsen (1973) har levert en marxistisk-basert kritikk av psykologifaget (med spesielt fokus på Freud). Med sitt fokus på økonomiske prosesser i arbeidslivet skiller disse forskerne seg fra sosiologene Aubert, Løchen og Hauglin, statsviterne Dahl og Jacobsen, medisineren Linden og sosionomen Grøsland som alle er opptatt av samfunnsmessige prosesser knyttet til staten og velferdsbyråkratiet. Det er rimelig å regne disse som å tilhøre det som i denne artikkelen blir omtalt som klientifiseringsperspektivet.

3. Talcott Parons (1902-1979), amerikansk professor ved Harvard Universitet fra 1944. Parsons ble særlig kjent for sine omfattende teoretiske arbeider innen sosiologien.

4. Myter handler vanligvis om fortellinger om hvor grupper kommer fra, og hvor de et på vei. Det dreier seg om trosoppfatninger som har karakter av å være metafortellinger. Disse fortellingene kan være historisk feil, men dette trenger ikke være tilfelle.

5. Takk til en anonym referee som påpekte dette poenget.

6. Aubert har også senere skrevet mye om samene (Aubert, 1978), og interessant nok blir ikke fattigdomstematikken tatt opp i denne mer omfattende analysen. En takk til Steinar Christensen, som sendte meg denne og andre bidrag til Aubert og andre, og som også kom med nyttige innspill i diskusjoner om denne artikkelen.

7. Diskusjonen til Aubert minner om problemet med «kasteballene» som var en viktig motivasjon for Nav-reformen, jf. f.eks. Hansen, Lundeberg \& Syltevik (2013). 
8. Bidragene til Aubert og Løchen i den første boken tilhører nokså åpenbart det som i senere tid er blitt omtalt som «den problemorienterte empirismen» (jf. Mjøset, 1991).

9. Går en nærmere inn på Berntsens kapittel, vil en se at det vil være mer presist å plassere dette kapittelet som «kritisk teori»(Berntsen, 1973). Marx er representert med en note, mens Marcuse er med med to referanser og Habermas med én referanse. Kritikken mot psykologifaget og argumentasjon for økt bevissthet om fagets ideologi og posisjon kan også sies å være i tråd med kritisk teori.

10. Burawoy (2004a, 2004b, 2005) tar utgangspunkt i om sosiologiske publikasjoner appellerer til et akademisk eller et ikke-akademisk publikum, og hvorvidt det blir produsert refleksiv eller instrumental kunnskap, og argumenterer ut fra dette at det finnes fire komplementære kategorier av sosiologi: profesjonell sosiologi, kritisk sosiologi, politisk sosiologi og offentlig sosiologi.

11. For mer omfattende diskusjoner av prosjektet til Burawoy (se f.eks. Clawson, 2007; Fatsis, 2014; Hanemaayer \& Schneider, 2014).

12. Det er i denne sammenhengen nærliggende å reise spørsmål om myteboken dreier seg om et generasjonsopprør. Tar en utgangspunkt i forfatternes alder, er det klart at den ikke dreier seg om en type «profil»-generasjonsopprør. Det er stor spredning i forfatternes alder, og de var i ulike aldre og livsfaser da viktige historiske begivenheter som den andre verdenskrig og innføringen av folketrygden fant sted. Den eldste forfatteren i boken (Gaustad, f. 1907) var f.eks. 33 år da andre verdenskrig brøt ut, og 60 år da folketrygden ble innført, mens den yngste (Lingås, f. 1947) var født to år etter andre verdenskrig og var 20 år da folketrygden ble innført. De fleste andre forfatterne var godt voksne da folketrygden ble innført. Gitt de forbedringene som velferdsstaten innebar, er det rimelig å tro at for de fleste forfatterne framstod velferdsstaten som et nytt byggverk som de har vært positive til. Kritikken deres kan således tolkes som at den gikk på oppfatningen om at byggverket var ferdig og var kommet på plass.

13. Thue (1998) siterer her fra Gunnar Skirbekks bok Nymarxisme og kritisk dialektikk (1970), der Skribekk skriver: «Poetokratiets tid er forbi. Litteraturveldet er over» (s. 284). Den samfunnsvitenskapelige tenkemåte kom ifølge Thue til å sette sitt preg på massemediene ikke minst gjennom de etter hver mange journalistene som hadde studert samfunnsfag i kortere eller lengre tid. Den samfunnsvitenskapelige debattbok-genren vokste frem i nært samspill med den nye venstresiden i Norge.

14. Boken som kom ut i 1995, hadde et eget kapittel om barns situasjon.

15. Ser vi på kjønnsfordelingen blant forfatterne, er det ikke overraskende at det ikke var større interesse for kvinners situasjon. I den første boken var det kun én kvinnelig forfatter, boken fra 1989 hadde ingen kvinnelige forfattere, mens boken fra 1995 hadde fem kvinnelige forfattere.

16. Kari Wærness hadde f.eks. i flere artikler pekt på at kvinner og menn hadde ulike posisjoner og roller når det gjaldt hus- og lønnsarbeid, og at dette også førte til at kvinner oftere enn menn ble mottakere av ulike ytelser fra velferdsstaten, men at kvinner generelt kom dårligere ut enn menn når det gjaldt størrelsen på ytelsene, og at trygderollen heller ikke ble opplevd på samme måte av kvinner og menn (jf. f.eks. Wærness, 1978, 1979). 
17. De to første bøkene hadde egne kapitler om fattigdom, skrevet av sentrale og profilerte fagpersoner (Aubert, Stjernø), og spesielt i den første boken var fattigdommen også et tema som ble tatt opp underveis i andre kapitler. I Myten om velferdsstaten - 25 år etter (1989) er det ikke noe eget kapittel om fattigdom, og det skrives også lite om fattigdom ellers i boken. Dette kan være et eksempel på det som Hagen og Lødemel (2010) har drøftet, nemlig at fattigdommen etter hvert forsvant både fra statistikkføringen og det offentlige ordskiftet, før temaet igjen dukket opp på dagsorden i tilknytning til stortingsvalget i 2001, da særlig fattigdommen blant barn ble et viktig område for offentlig politikk og forskning.

18. I en omfattende rapport fra SSB viser Epland og Kirkeberg (2016) til at i 2014 tilhørte $9,4 \%$ av alle barn i Norge lavinntektsgruppen, slik dette vanligvis blir beregnet i henhold til EUs mål om at en da tilhører hushold som ligger under $60 \%$ av medianinntekten i samfunnet. Blant alle personer i hushold med én forsørger hadde $27 \%$ lavinntekt (EU) dette året, mens det tilsvarende tallet for de som bodde i parhushold med barn (under 18 år) var 8 \%. For begge husholdstyper har det i perioden 1996 til 2014 blitt stadig flere barn i lavinntektsgruppen, og den samme utviklingen gjør seg også gjeldende om en ser på andelen barn som lever under vedvarende lavinntekt (tre år på rad med lav inntekt). Forklaringene på denne utviklingen er ifølge Epland og Kirkeberg (2016) at den manglende indeksreguleringen av barnetrygden og den økte innvandringen.

\section{Referanser}

Aubert, V. (1973). Fattigdommen i Norge. I L.G. Lingås (Red.), Myten om velferdsstaten. Når velferdsstaten alle? (s. 16-33). Oslo: Pax forlag.

Aubert, V. (1970). Rural Poverty and Community Isolation. I P. Townsend (Red.), The Concept of Poverty. Working papers on methods of Investigation and Life-Styles of the poor in Different Countries (s. 236-250). London: Heineman.

Aubert, V. (1978). Den samiske befolkningen i Nord-Norge. (SSB Artikler nr. 107/78). Oslo-Kongsvinger: Statistisk sentralbyrå.

Berntsen, H. (1973). Samfunnsstruktur og psykologi. I L.G. Lingås (Red.), Myten om velferdsstaten. Søkelys på norsk sosialpolitikk (s. 163-173). Oslo: Pax forlag.

Burawoy, M. (2004a). «For Public Sociology». American Sociological Review, 70, 4-28. https://doi.org/10.1177/000312240507000102

Burawoy, M. (2004b). Public Sociologies: Contradictions, Dilemmas, and Possibilities. Social Forces, 82, 1603-1618. https://doi.org/10.1353/sof.2004.0064

Burawoy, M. (2005). Presidential address: For public sociology. The British Journal of Sociology, 56, 259-294. https://doi.org/10.1111/j.1468-4446.2005.00059.x

Clawson, D., Zussman, R., Misra, J., Gersten, N., Stokes, R. \& Anderton, D.L. (Red.), (2007). Public Sociology: Fifteen Eminent Sociologists Debate Politics and the Profession in the Twenty-first Century. Berkeley-Los Angeles, CA: University of California Press. 
Dahl Jacobsen, K. (1973). Politisk fattigdom. I L.G. Lingås (Red.), Myten om velferdsstaten. Søkelys på norsk sosialpolitikk (s. 175-181). Oslo: Pax forlag.

Dahl, H.F. (1973). Det usynlige Norge. I L.G. Lingås (Red.), Myten om velferdsstaten. Søkelys på norsk sosialpolitikk (s. 13-16). Oslo: Pax forlag.

Dahl, H.F. (2012). Fra Pax til Paven. Minner om meninger. Oslo: Aschehoug.

Engelstad, F. (Red.) (2000). Kunnskap og refleksjon. 50 års samfunnsforskning. Institutt for samfunnsforskning. Oslo: Institutt for samfunnsforskning.

Epland, J. \& Kirkeberg, M.I. (2016) Barnefamilienes inntekter, formue og gjeld 2004-2104 (SSB Rapport 11/16). Oslo-Kongsvinger: Statistisk sentralbyrå.

Fatsis, L. (2014). Making sociology public: A critical analysis of an old idea and a recent debate. ( $\mathrm{PhD}$ avhandling). School of Law, Politics and Sociology, University of Sussex.

Grøsland, G. (1973). De psykisk utviklingshemmede i vårt samfunn. I L.G. Lingås (Red.), Myten om velferdsstaten. Søkelys på norsk sosialpolitikk (s. 118-137). Oslo: Pax forlag.

Hagen, K. \& Lødemel, I. (2010). Fattigdomstiåret 2000-2010 : Parentes eller ny kurs for velferdsstaten ? I I. Frønes \& L. Kjølsrød (Red.), Det norske Samfunn (6. utg.) (s. 284-307). Oslo: Gyldendal Akademiske.

Halvorsen, (2017). Sosiale problemer - en sosiologisk innføring (2. utg.). Bergen: Fagbokforlaget.

Hanemaayer, A. \& Schneider, C.J. (Red.) (2014). The Public Sociology Debate: Ethics and Engagement. Vancouver, BC: University of British Columbia Press.

Hanoa, R.O. (1973). Klasse og sykdom. I L.G. Lingås (Red.) Myten om velferdsstaten. Søkelys på norsk sosialpolitikk (s. 80-101). Oslo: Pax forlag.

Hansen, H.-T., Lundberg, K.G. \& Syltevik, L.J. (2013). Nav - med brukeren i sentrum? Oslo: Universitetsforlaget.

Helsvig, K.G. (2014). Pax Forlag 1964-2014. Oslo: Pax forlag.

Hills, J. (2017). Good times, bad times: the welfare myth of them and us. Bristol: The Policy Press.

Gubrium, E. \& Lødemel, I. (2014). Social assistance and shaming in Norway. I E.K. Gurbruim, S. Pellissery \& I. Lødemel (Red.), The shame of it. Global perspective on anti-poverty politics. Bristol: Policy Press.

Kalleberg, Ragnvald (200o). 'The Most Important Task of Sociology Is to Strengthen and Defend Rationality in Public Discourse': On the Sociology of Vilhelm Aubert. Acta Sociologica, 43, 399-411. https://doi.org/10.1177/ooo169930004300412

Kolberg, J.E. (1973). Det klientskapende systemet. I L.G. Lingås (Red.), Myten om velferdsstaten. Søkelys på norsk sosialpolitikk (s. 139-152). Oslo: Pax forlag.

Kolberg, J.E. (1991). En empirisk utprøving av utstøtingsmodellen. I A. Hatland (Red.), Trygd som fortjent (s. 91-117). Oslo: Ad Notam. 
Lingås, L.G. (Red.) (1970). Myten om velferdsstaten. Når velferdsstaten alle? Oslo: Pax forlag.

Lingås, L.G. (Red.) (1973). Myten om velferdsstaten. Søkelys på norsk sosialpolitikk. Oslo: Pax forlag.

Lingås, L.G. (Red.) (1989). Myten om velferdsstaten - 20 år etter. Oslo: Pax forlag.

Lingås, L.G. (Red.) (1995). Myten om velferdsstaten - 25 år etter. Oslo: Pax forlag.

Løchen, T. (1973). Velferdsstatens handicap. I L.G. Lingås (Red.), Myten om velferdsstaten. Søkelys på norsk sosialpolitikk (s. 33-49). Oslo: Pax forlag.

Mjøset, L. (1991). Kontroverser i norsk sosiologi. Oslo. Universitetsforlaget.

Nestor, P. (1973). Kapital og klienter. I L.G. Lingås (Red.), Myten om velferdsstaten. Søkelys på norsk sosialpolitikk (s. 152-163). Oslo: Pax forlag.

Nielsen, F. (2004). The Vacant 'We': Remarks on Public Sociology. Social Forces, 82, $1619-1627$.

Sand, H.P. (2014). Norwegian Sociology and the recognition of the Saami minority. Advances in Applied Sociology, 135-140. http://dx.doi.org/10.4236/ aasoci.2014.45017

Svensson, N.P. 1973. Velferdssamfunn eller klassesamfunn. I L.G. Lingås (Red.), Myten om velferdsstaten. Søkelys på norsk sosialpolitikk (s. 181-192). Oslo: Pax forlag.

Thue, F.W. (1990). Røttene til norsk etterkrigssosiologi. Sosiologi i dag, 20(4), 27-47. Hentet fra http://ojs.novus.no/index.php/SID/index

Thue, F.W. (1997). Empirisme og demokrati: Norsk samfunnsforskning som etterkrigsprosjekt. Oslo: Universitetsforlaget.

Thue, F.W. (1998). Samfunnsforskningens prosa mellom vitenskap og litteratur. I. E.B. Johnsen \& T.B. Eriksen (Red.), Norsk litteraturhistorie. Sakprosa fra 1750 til 1995 (Bind 2). (s. 284-296). Oslo: Universitetsforlaget.

Thue, F.W. (200o). Den atlantiske forbindelse. ISF i det amerikansk-europeiske forskningssamarbeid, 1945-1953. I F. Engelstad (Red.), Kunnskap og refleksjon. 50 års samfunnsforskning. Oslo: Institutt for samfunnsforskning.

Thue, F.W. (2006). In quest of a democratic social order: the Americanization of Norwegian social scholarship 1918-1970 (Acta humaniora, trykt utg. nr. 262) (Dr.philos.-avhandling). Unipubavhandlinger, Universitetet i Oslo.

Stjernø, S. (1989). Fattigdommen og fattighjelpen - ved et vendepunkt? I L.G. Lingåas (Red.), Myten om velferdsstaten - 20 år etter (s. 11-41). Oslo: Pax forlag.

Wærness, K. (1978). The Invisible Welfare State: Womens's Work at Home. Acta Sociologica - Supplement, 21 (s. 193-207). Hentet fra http://www.jstor.org/ stable/24859739

Wærness, K. (1979). Kvinner og trygd. I J.E. Kolberg \& K. Wærness (Red.), Trygd og samfunn. Oslo: Universitetsforlaget. 



\title{
Myten om at ein stor stat fører til eit svakt samfunn
}

\author{
Atle Møen, professor, Universitetet i Bergen, Sosiologisk institutt
}

\section{Abstract}

Title: The Myth that a Strong State Leads to a Weak Society. Summary: This article discusses the myth that a strong state makes for a weak society. This is a myth evident both in the view that a comprehensive welfare state entails a weak civil society and the hypothesis that big government "crowds out" social capital. The article examines both of these views against the backdrop of the historical relationship between state and civil society in Norway. First, rather than undermining civil society, the article demonstrates how a strong welfare state has in fact co-existed with and encouraged over time the vitality of civil society, based on social movements with broad recruitment bases. In the Nordic countries, a specific kind of "state individualism" has also emerged. Second, the article argues that this strong civil society - today visible, for example, in the vitality of labour unions and growing participation in voluntary organizations in the fields of culture, sport and recreation - generates bridge-building social capital, thus weakening the "crowding-out" hypothesis. The final section of the article examines the myth that older people cared for by family members receive better care than those in the public healthcare system, in light of evidence that indicates care from family members can lead to asymmetrical relations or perceived indignity which in turn can jeopardize the quality of the interaction between the older person and the caregiver.

Keywords: welfare state, state individualism, bridge-building social capital, public institutions, voluntary organizations

\section{Innleiing}

Det har vore ein lang tradisjon i Noreg å ha tiltru til at den demokratiske staten representerer allmenne interesser, og at ein kan løysa felles oppgåver gjennom demokratiske institusjonar. Det har også for det meste vore

Sitering av denne artikkelen: Møen, A. (2018). Myten om at ein stor stat fører til eit svakt samfunn. I K. Christensen \& L.J. Syltevik (Red.), Myter om velferd og velferdsstaten (s. 39-58). Oslo: Cappelen Damm Akademisk. https://doi.org/10.23865/noasp.47.ch2

Lisens: CC BY-NC 4.0 
brei oppslutning om velferdsstaten og offentlege institusjonar som yter tenester til heile folket. Det er likevel også eit vanleg synspunkt, særskilt på høgre fløy i politikken, at ein stor stat fortrengjer den frivillige organiseringa i det sivile samfunnet, fører til at den individuelle fridommen minkar, reduserer den gjensidige tilliten mellom folk, svekker den sosiale kapitalen og skaper eit passivt samfunn. Dette perspektivet stammar frå det ein kan kalla «den angloamerikanske statsteorien», som formidlar ein tese om at den store staten, «big government», fører til at vitaliteten i det sjølvorganiserande sivile samfunnet vert svakare, noko som i engelsk språkdrakt vert omtala som «crowding out»-hypotesen (Rothstein, 2011; Selle 2008; Trägårdh, 2008). Dette synspunktet finst i det politiske ordskiftet, gjerne i saman med ein pragmatisk aksept av den sterke og omfattande staten.

Eg vil i denne artikkelen forsøka å visa at dette med at ein omfattande velferdsstat skaper eit svakt samfunn, er ein myte. Dette synet finst også i den liberale politiske teorien som har som ein premiss at individuell fridom berre er mogleg gjennom negativ fridom, noko som vil seia å avgrensa innblandinga og reguleringa frå staten. I denne liberale politiske teorien er det ikkje noko avgjerande skilje mellom den absolutte staten, eller den totalitære staten, og den demokratiske velferdsstaten: Statsmakt i seg sjølv vil medføra å innskrenka den individuelle fridommen og redusera aktiviteten i eit sjølv-organiserande samfunn.

I denne artikkelen vil eg støtta meg på eit republikansk perspektiv på statsmakta, noko som hevdar at menneska berre kan oppnå fridom innanfor ein polis, gjennom offentlege institusjonar, eller innanfor ein demokratisk fellesskap (Skinner, 2011). Individa kan auka sin fridom gjennom å skapa felles institusjonar, og menneska kan bli mindre avhengige av personlege band innanfor familien og meir uavhengige av den vilkårlege marknaden gjennom å ha tilgang til alternativ inntekt gjennom velferdsstaten, slik at individa kan stilla krav om god nok lønn og tilfredsstillande arbeidsvilkår. På denne måten kan den individuelle fridommen auka gjennom å skapa offentlege institusjonar innanfor rammene til den demokratiske statsmakta. Dette synspunktet er den rake motsetnaden til synspunktet om «velferdsavhengigheit», som gradvis har blitt eit subtilt åtak på velferdsstaten (sjå Vogts artikkel). 
Når menneska lever mykje av livet sitt innanfor offentlege institusjonar som er meint for alle, kan det skapast grunnlag for at menneska får gjensidig tillit til kvarandre, fordi dei samhandlar og møter kvarandre i felles sosiale rom. Dersom skulen, universiteta, barnehagane og sjukehusa fungerer upartisk og handsamar alle likt, men også yter tenester etter individuelle behov, er effektive og rettferdige i ressursbruken, og gjer at den enkelte opplever vedkjenning og respekt i møte med institusjonane, vil mange også få tiltru til desse offentlege institusjonane og tillit til dei personane dei møter. Denne tilliten er sjølvsagt ikkje blind, men oppstår under vilkår av gode erfaringar av dei som arbeidar innanfor desse institusjonane. I nordiske land vil dei fleste difor ikkje oppleva staten som ei autoritær og utvendig tvangsmakt, men heller som ein inkluderande og demokratisk fellesskap som yter ei teneste til alle medborgarane.

I denne samanhengen vil eg framheva eit døme på skilnaden mellom ein autoritær stat og ein demokratisk stat. I mange austeuropeiske land har det vore «kampanjar» mot det norske barnevernet. Eg tar ikkje stilling til denne kritikken om at det norske barnevernet tar barna frå foreldra utan gode grunnar, og det er viktig å retta søkjeljoset mot at barnevernet også kan gjera galne vedtak og overta barneomsorga på sviktande grunnlag. Men likevel kan kanskje dette også illustrera eit meir generelt poeng. I desse austeuropeiske statane har folk mest erfaring med ein autoritær stat som utøver illegitim tvangsmakt, og difor har dei vanskeleg for å førestilla seg at det norske barnevernet også kan hjelpa familiar med vanskar av eit eller anna slag, og at barnevernet òg strever etter å gjera vedtak som er det beste for barnet. Dette er ein utenkjeleg praksis innanfor autoritære statar.

Eg vil undervegs argumentera for at den demokratiske og universelle velferdsstaten, offentlege tenestemenn -og kvinner, dei breie folkerørslene, den statlege individualismen, dei frivillige organisasjonane og dei opne og inkluderande offentlege institusjonane dannar ulike aspekt av res publica, eller den offentlege tingen. Det er difor ein indre samanheng mellom velferdsstat, demokrati og universell og inkluderande samfunnssolidaritet. Det er denne «sivilisasjonen», med ein demokratisk velferdsstat med medborgarsolidaritet, tenesteinstitusjonar som er opne for alle, reguleringar og organisering i arbeidslivet, som er under åtak av den teknokratiske utopien om den sjølvregulerande marknaden (Bourdieu, 1998). 
Eg startar med ei kort historisk skisse av det særeigne ved Noreg og Norden. I Noreg har den «sterke» staten også utvikla seg i takt med folkelege og demokratiske rørsler, slik at det har vore både eit aktivt samfunn og ein sterk og demokratisk stat. I dei nordiske landa har det også vore vanleg med «statsindividualisme», noko som ofte har medført individuell frigjering gjennom velferdsstaten. Det er også slik i dag at den politiske interessa og rolla som medborgarar er mest utvikla innanfor institusjonelle og universelle velferdsstatar, mens i meir selektive velferdsstatar er det færre grunnar til politisk deltaking. Eg vil også leggja vekt på at medborgarskapen vert stadfesta gjennom at dei fleste vert inkluderte innanfor offentlege institusjonar, noko som kan skapa meir universell solidaritet og «bru-byggjande sosial kapital». Dette vil medføra at det vert danna nettverk og gjensidig tillit mellom menneske som er ulike kvarandre i alder, klasse, og etnisk tilhøyrsle (Putnam 2007, s. 143). Det særskilte med mitt perspektiv er at eg peikar på at denne «bru-byggjande sosiale kapitalen» først og fremst vert danna gjennom deltaking innanfor offentlege institusjonar. Eg vil vidare hevda at den universelle velferdsstaten går i saman med sterk aktivitet innanfor frivillige organisasjonar, særleg innanfor kultur, fagforeiningar og idrett. Eg avsluttar med å argumentera for at kvaliteten på omsorga både andsynes barn og eldre er best dersom offentlege institusjonar har eit stort ansvar for den daglege omsorga. Det er ein myte at eldre menneske har det så godt når dei blir tekne hand om av barna sine. Dette kan føra til uverdige og underlegne relasjonar, der den som tek imot hjelp må framføra ein vedvarande takk, noko som kan gjera samhandlinga mellom frie og like menneske vanskeleg.

I analysemodellen under, som samsvarar med dei enkelte avsnitta, ser eg på ulike aspekt av eit aktivt samfunn. Velferdsstaten skaper ein form for aktivt samfunn og eit vitalt sivilt samfunn, den demokratiske staten har utvikla seg i takt med sosiale rørsler, noko som bidrog til å skapa individuell fridom, eller ein statsindividualisme, offentlege institusjonar bidreg til å skapa sosial kapital i samfunnet, og endeleg er det slik at det aktive samfunnet i Noreg også er kjenneteikna av omfattande frivillig organisering, noko som også bidreg til omfattande tillit i samfunnet, eller bru- byggjande sosial kapital. 


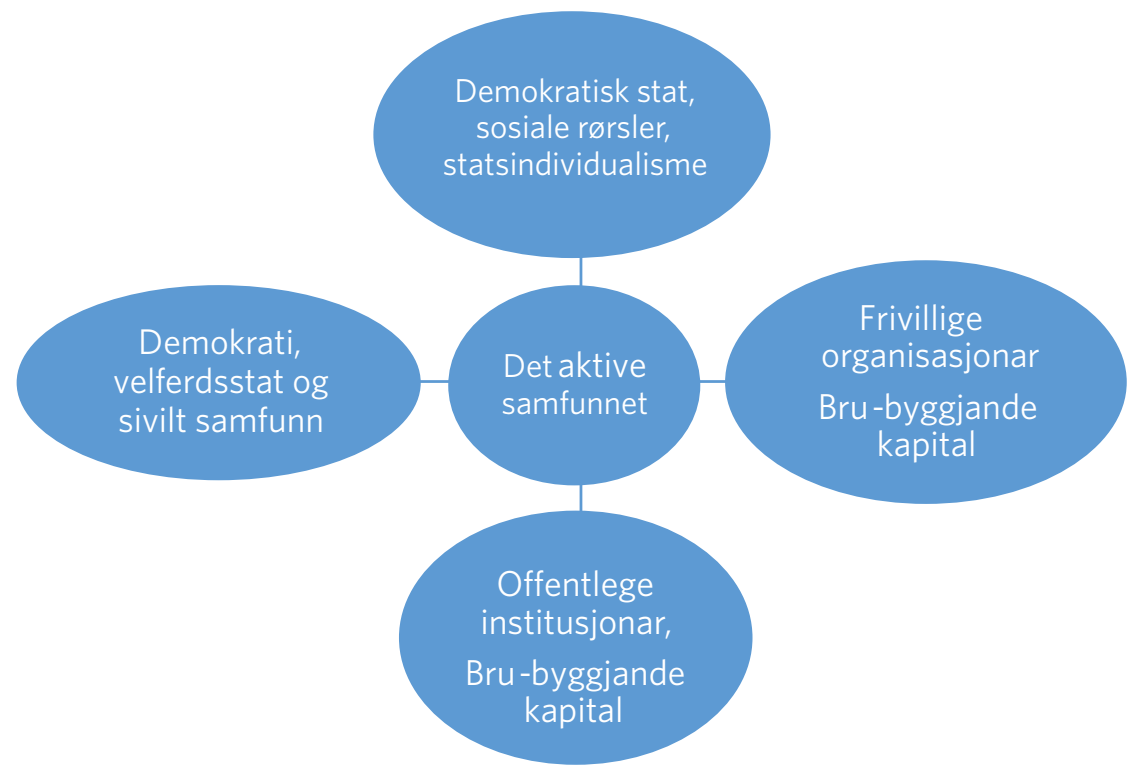

Figur 1. Analysemodell.

\section{Demokratisk stat, sosiale rørsler og statsindividualisme}

I Noreg utvikla dei demokratiske folkerørslene seg i eit samspel med framveksten av embetsmannsstaten, der juristane og dei lutherske prestane representerte «opplysning» og fornuft, og embetsmennene spela viktige roller i moderniseringa av Noreg. Gunnar Skirbekk hevdar at den norske moderniseringa var kjenneteikna av at juristane bidrog til framveksten av rettsstaten og individuelle rettar, og av at dei lutherske prestane fremja «ein pastoral opplysning» i dobbel tyding: Det første var at dei lutherske prestane var ein viktig del av statsadministrasjonen, og den andre tydinga var at desse embetsmennene var spreidde utover heile landet, slik at heile folket fekk eit direkte møte med statstenestemennene som både representerte «opplysning» og innøving i skriftspråket. Dette utløyste difor eit samspel mellom lutherske embetsmenn og framveksten av folkerørsler, slike som haugianismen, Thranerørsla, og bonderørsla med Søren Jaabæk som karismatisk leiar (Skirbekk, 2010). Dette skapte grobotn for ei statsmakt som ville retta seg direkte til dagleglivet til folk, og handsame folket som enkeltindivid som sto direkte under embetsmennene og statsmakta. 
Dette samspelet mellom embetsstaten og folkerørslene opna også ein utveg til frigjering gjennom statsmakta, i mykje større grad enn innanfor andre europeiske statar. Både bøndene og seinare arbeidarane og kvinnene auka sin makt og styrkte sin fridom både gjennom å organisera seg $\mathrm{i}$ folkerørsler og gjennom å gjera bruk av ei sentral statsmakt som var open for demokratisering. Det mest tydelege dømet på dette samspelet mellom sosial rørsle og sentralisert stat fanst innanfor den svenske og den norske sosialdemokratiske maktmobiliseringa. Sosialdemokratiet var både ei brei sosial rørsle, med utspring i arbeidarfellesskap og fagforeiningar, og eit statsberande og eliteprega politisk parti (Trägårdh, 2008, s. 587). Denne organisasjonsmodellen vart også vidareført og vidareutvikla gjennom at kvinnerørsla og feminismen også vart gjort politisk effektiv gjennom å erobra viktige posisjonar innanfor staten, og iverksetjing av ny politikk gjennom «statsfeminismen». Denne folkerørslemodellen var svært fleksibel og effektiv på den måten at det vart mogleg å kombinera stor aktivitet på lokalnivå med sentralisert leiarskap (Selle, 2008, s. 622). Den lutherske statsadministrasjonen skapte eit av mønstera for denne (sosialdemokratiske) folkerørslemodellen, som altså kombinerte sterk lokal organisering med ei sterk statsmakt med juristar og lutherske prestar i statseliten.

Det har også vore ein diskusjon om vi kan skildra ein særleg norsk veg, frå reformasjonen, via 18oo-talet og fram til den sosialdemokratiske velferdsstaten. Francis Sejersted skapte omgrepet «demokratisk kapitalisme» for å skildra ein særleg veg, ein norsk samfunnsformasjon som tok form gjennom 180o-talet med eit liberalt borgarskap, opplyste embetsmenn i statsforvaltninga og med ein sjølvstendig akademisk kultur som fremja eit syn på liberal fridom, delvis i opposisjon til den økonomiske individualismen. Dette opna for ein sosial-liberal modell som kunne kombinera økonomisk liberalisme med sosial integrasjon gjennom velferdsstaten og ein institusjonell «statsindividualisme» som eit alternativ til den økonomiske individualismen (Stråth 2016, s. 285; Trägårdh, 2008). Denne statsindividualismen medførte at den individuelle fridommen kunne realiserast innanfor ein demokratisk stat med rettferdige og effektive offentlege institusjonar. På dette viset kunne sosialdemokratiet seinare på 1900-talet fylla nytt innhald i dei historiske formene som særleg vart danna gjennom 180o-talet. 
Innanfor den angloamerikanske statsteorien, den liberale politiske teorien og den meir generelle politiske diskusjonen er det ofte blitt fokusert på at den individuelle fridommen må vinnast gjennom å avgrensa staten sine inngrep i det private livet og det sivile samfunnet med både frivillige organisasjonar og den sjølvregulerande marknaden. Ein sterk stat reduserer ifylgje desse tankefigurane den individuelle fridommen. På den andre sida har mellom anna den svenske samfunnsforskaren Lars Trägårdh (2008) hevda at det innanfor dei skandinaviske landa har vore ein «statsindividualisme», eller individuell frigjering, gjennom mellom anna velferdsstaten og individuelle pensjonsrettar. Dette kan forståast som ein type republikansk fridom, noko som vil seia fridom forstått som uavhengigheit av vilkårleg makt, slik som familien, marknaden, lokalsamfunnet, den religiøse gruppa, arbeidsgjevar og for kvinnene: uavhengigheit frå mennene (Skinner, 2011). Velferdsstaten har nettopp gjeve tilgang til kollektive ressursar som har gjort mogleg denne individuelle fridommen i ulike ovringar. Den skandinaviske velferdsstaten sette individet i ein direkte relasjon til staten, og frigjorde den enkelte frå avhengigheit frå marknaden, frå familien og filantropiske fattighjelp, i langt sterkare grad enn det som var tilfelle innanfor andre typar velferdsstatar. I dei konservative velferdsstatane vart pensjonsytingar meir utbetalte til familiane, gjerne med kvinnene som heimearbeidande. I dei selektive og behovsretta liberale velferdsstatane vart individa enten avhengige av private forsikringar eller av fornedrande behovsprøvde utbetalingar. I Skandinavia vart pensjonsrettane direkte knytt til enkeltindivida uavhengig av familie, yrke, fagforeiningar og andre tilknytingar (Esping-Andersen, 1990).

Denne skandinaviske statsindividualismen eksisterte også lenge før utbygginga av velferdsstaten. Det er gjerne vanleg å hevda at reformasjonen og den protestantiske statskyrkja fremja ein direkte relasjon mellom individet og embetsmannsstaten. Det var eit viktig særpreg i Skandinavia at det vart skipa til statskyrkjer, noko som skilte desse landa frå dei fleste andre land med katolske kyrkjer, som gjerne var uavhengige frå statsmakta og ei konkurrerande transnasjonal makt. Dei lutherske statskyrkjene fremja individualisme, mellom anna av di frelsa var avhengig av den enkelte si tru og samvit, og ikkje som i katolske kyrkjer, der deltaking i den rituelle fellesskapen var avgjerande for å oppnå frelsa. Eit 
eksempel på denne individualismen innanfor den lutherske statskyrkja og den særskilde relasjonen mellom stat og individ var at ekteskapslovgjevinga mellom 1850 og 1930 var retta inn mot individuelle kontraktar, og dette syner kor lite familieorientert denne lovgjevinga var. Dette gav særskilt dei nordiske kvinnene ein sterkare individuell fridom enn det som var vanleg elles i Europa (Selle 2008, s. 618).

\section{Demokrati, velferdsstat og sivilt samfunn}

I land med institusjonelle og universelle velferdsstatar er også den politiske interessa mest utvikla, av den enkle grunn at det finst gode grunnar til å engasjera seg politisk. Det at ein velferdsstat er institusjonell og universell, vil seia at staten også har ansvar for utdanning, helse og omsorg, og at heile folket er inkludert innanfor dei same institusjonane. Velferdsstaten vedkjem livsvilkåra på mange felt, og det at offentlege institusjonar yter gode tenester, er viktig for nesten alle (Bauman, 1998). Det er gode grunnar til å vera engasjert i den politiske diskusjonen, og dette vil difor seia at velferdsstaten styrkjer demokratiet og den offentlege sfære. Dette vil seia at eit aktivt demokrati må ha ein «bruksverdi» i å skapa offentlege institusjonar og universelle pensjonsrettar gjennom politikken, berre gjennom denne «bruksverdien» er det meiningsfullt for dei fleste å bli aktive demokratiske medborgarar. Velferdsstaten avgrensar rekkevidda til marknaden gjennom å gje alternative inntekter og offentlege tenester, og skaper på denne måten oppslutnad om og legitimitet for demokratiet (Habermas, 2001, s. 51).

I land med selektive og behovsprøvde velferdsordningar er interessa for politikk mindre, og det er ein tendens til framvekst av motsetnadar mellom dei som klarer seg med marknadsretta sosiale forsikringar, og dei som er avhengige av behovsprøvd velferd. Det å ta imot behovsprøvde velferdstiltak er også fornedrande, og det finst gode grunnar til å skjula det at ein er avhengig av velferd, og difor er det gode grunnar til å ikkje løfta slike problem fram i den offentlege sfære og i det politiske ordskiftet. Det finst ikkje ein solidaritet mellom likestilte medborgarar som kan støtta opp under ein demokratisk politikk som betrar velferda for dei fleste. 
Ein aktiv medborgarfellesskap vert kontinuerleg skapt gjennom politiske inngrep som etablerer velferdsinstitusjonar, og dette skaper samstundes ein relativt aktiv og vel fungerande demokratisk politikk. Det var til dømes etablering av folketrygda med inntektsavhengige tilleggsforsikringar og etter kvart ein sjenerøs institusjonell tenesteproduksjon som bidrog til å skapa ei stor veljargruppe som hadde interesse av å vidareføra ein universell velferdsstat, som også innehaldt offentleg tenesteproduksjon innanfor utdanning, helse og omsorg. I motsett fall, viss det først vert innført private forsikringar, og privatisering av utdanning, helse og omsorg, vil det danna seg eit nytt politisk kollektiv som har interesse av å vedlikehalda privatiseringa av velferdsstaten (Esping-Andersen, 1985). Dette vil også seia at ein selektiv og behovsretta velferdsstat skaper minimal interesse for politikk, mens universelle velferdsinstitusjonar bidrar til å skapa aktive medborgarar og omfattande interesse for politikk. Det er slik at eksistensen av selektive velferdsstatar fører til at politikken vert mindre viktig og det politisk aktive statsborgarskapet vert innskrenka (Bauman, 1998, s. 50).

Det har også, særskilt i USA, men også i mange andre land, vore ein overgang frå velferdspolitikk til ein disiplinerande sosialpolitikk, noko som kan skildrast som ein overgang frå «welfare» til «work-fare» og «prisonfare» (Wacquant, 2014). Kvaliteten på og profilen på demokratiet vert endra dersom marknadsplassen ekspanderer slik at statsborgarar vert omforma til kundar, eller dersom politikken einsidig vert retta inn mot disiplin og overvaking av marginaliserte, innvandrarar og kriminelle. Den politiske diskusjonen innanfor den offentlege sfære vert fokusert mot ein kamp mot farlege «fiendar» heller enn å utvikla kollektive gode innanfor ein republikansk fellesskap.

Frå eit normativt-empirisk synspunkt kan ein seia at velferdsstaten styrkjer ulike aspekt ved det sivile samfunnet og den offentlege sfære. Velferdsstaten med sine tenesteinstitusjonar har også innslag av det sivile samfunnet i offentlege tenester som er grunna i formell likskap og universelle tilbod (Alexander, 2006; Møen, 1999). For det første fremjar velferdsstaten, som eg alt har vore inne på, ei brei interesse for politikk og ei offentleg sfære for diskusjon og rådslaging om politikk. Dette styrkjer den kollektive autonomien i samfunnet, forstått som demokratisk 
rådslaging innanfor ein offentleg sfære (Wagner, 2012). For det andre aukar den individuelle autonomien, eller fridommen, fordi velferdsstaten yter kollektive ressursar som gjer menneska mindre avhengige av marknaden og familien, og gjev individa fridommar som sivile medborgarar og statsborgarar. For det tredje vert den universelle statsborgarrolla styrka både på kostnad av religiøse identitetar, og på kostnad av rolla som konkurrentar på marknadsplassen. Menneska vert difor både meir uavhengige av den etniske og religiøse fellesskapen og meir uavhengige av vilkårlege marknadssvingingar, slik at ein til dømes kan leva på arbeidsløysetrygd i tilfelle arbeidsløyse. Velferdsstaten reduserer ulikskapen, skaper meir samarbeidande fellesskap og fleire «universelle» fellesskap, noko som skaper meir effektive og rettferdige samfunn og mindre innslag av fornedrande og stressande statuskonkurranse (Wilkinson \& Pickett, 2012).

\section{Offentlege institusjonar og bru-byggjande sosial kapital}

I Norden og Noreg har vi ein stor offentleg sektor med offentleg finansierte barnehagar, offentlege skular og offentlege universitet, eit felles sjukehusvesen og omsorgstenester og ei folketrygd der alle er medlemmar. Dette gjer at heile folket deltek med felles plikter og rettar innanfor dei same institusjonane, som også kan seiast å vera del av det sivile samfunnet. Dette fører til eit felles medborgarskap, sosial likskap, og at alle har interesse av å vera politisk aktive. Politikken vedkjem velferda for dei fleste, og difor er det rasjonelt å engasjera seg som aktiv statsborgar. Det er ein relativt sterk solidaritet mellom medborgarar i eit slikt samfunn, fordi menneska møter kvarandre i felles institusjonar, og ikkje så mykje fordi dei har den same kulturen.

Det er alltid lettare å forstå eit sosialt fenomen gjennom å samanlikna med andre og kontrastfulle sosiale fenomen. I USA kan ein finna kontrasten til dette aktive norske samfunnet og den relativt vel fungerande demokratiske politikken som finst i Noreg. I USA har det vakse fram ein eksepsjonell sosial ulikskap, men likevel finst det ikkje særleg med demokratisk mobilisering mot denne ulikskapen, og det er mangel på den 
typen medborgarskapleg solidaritet som er vesentleg i den demokratiske politikken (Mann, 2013, s. 336). Det at det ikkje finst universelle velferdsinstitusjonar, medfører også at ulikskapen aukar, og det vert heller ikkje skapt den type bru-byggjande sosial kapital som kan oppstå av dagleg deltaking innanfor offentlege institusjonar. I og med relativ mangel på universelle institusjonar, slik som til dømes ein offentleg skule, offentleg helsevesen og eit universelt trygdesystem, er det lite med samhandling mellom ulike og frie menneske i det daglege livet. Det er ganske enkelt færre møteplassar for menneske som er ulike kvarandre når det gjeld status, inntekt, religion og etnisk tilhøyrsle, og difor vert det danna få nettverk og liten gjensidig tillit mellom menneska.

Det er vanleg å skilja mellom eit samfunnssentrert og eit institusjonssentrert syn på kva som genererer den sosiale kapitalen. Det samfunnssentrerte synet meiner at frivillige organisasjonar genererer sosial kapital, mens det institusjonssentrerte perspektivet hevdar at det er gode offentlege institusjonar og høg kvalitet på styresettet som genererer sosial kapital og tillit menneska imellom og tillit til offentlege styresmakter (Rothstein 2011, s. 148-151) Det er eit sentralt poeng i denne framstillinga at denne typen sosial kapital vert i minst like stor grad skapt innanfor offentlege barnehagar, skular og sjukehus som innanfor frivillige organisasjonar.

Den selektive og behovsprøvde velferdspolitikken er spesielt retta inn mot dei som treng det mest, og dette fører til at det er nedverdigande å gå på welfare, noko som fører til negativ oppfatning av slik velferdspolitikk også for dei som tek imot denne forma for hjelp (sjå også Sylteviks artikkel). Det er heller ikkje ærefullt å «gå på sosialhjelp» her i landet, og det er ikkje det første som vert tematisert i eit middagsselskap, og det finst nesten ikkje demokratisk mobilisering for å auka sosialstønaden. Det vert heller ikkje bygt ut offentlege institusjonar som inkluderer alle i slike land med selektive velferdsordningar. Dette fører også til at selektiv og behovsprøvd velferdspolitikk ikkje genererer bru-byggjande sosial kapital, gjensidig tillit og omfattande samfunnssolidaritet. Den demokratiske politikken manglar også relevans når det gjeld rettferdig fordeling, og politiske engasjement har dreia vekk ifrå velferdsspørsmål og i retning av identitetspolitikken, slik som kjønn, rase, seksuell identitet og 
religion. Dette er sentrale tema som fokuserer på individuell frigjering og skaper sosiale rørsler og demokratisk mobilisering, men auke i den sosiale ulikskapen kan likevel skje i ly av identitetspolitikken (Fraser, 200o). Det er mykje som tyder på at ein behovsprøvd og selektiv velferdspolitikk fører til at velferdspolitikken ikkje er den «bruksverdi» som kan bidra med å skapa politisk interesse og demokratisk legitimitet. Dette fører identitetspolitikken inn i det politiske sentrum, både den type identitetspolitikk som medfører frigjering av svarte, kvinner, homofile og funksjonshemma, og den undertrykkjande og potensielt valdelege rasismen og valda mot minoritetar.

Men aller mest opplever menneska solidaritet dersom dei deltek innanfor samarbeidande sosiale fellesskap, og dersom dei vert inkluderte innanfor felles institusjonar, både frivillige organisasjonar og offentlege institusjonar. På denne måten skaper den institusjonelle velferdsstaten ein universell samfunnssolidaritet gjennom folketrygda, helsevesenet, barnehagane, omsorgstenestene og gjennom dei offentlege utdanningsinstitusjonane. Det er nettopp denne vedvarande deltakinga innanfor offentlege institusjonar som skaper universell solidaritet og bru-byggjande sosial kapital (Putnam, 2007).

Kontrasten til dette kan vera eit nabolag med stor sosial ulikskap og svake offentlege institusjonar, til dømes i Brasil eller i USA, der fattige og rike, svarte og kvite knapt møter kvarandre og samhandlar lite i det daglege livet. Dei velståande går på eigne skular, det finst ikkje eit felles helsestell der dei kvite og rike kan møta fattige og farga, og sjølvsagt er det private barnehagar for dei privilegerte, mens dei som har mindre, gjerne farga, ofte har omsorg for eigne barn, gjerne med hjelp frå andre i familien enn mora. Det mest vanlege er at dei som er ulike kvarandre med omsyn til velstand, religion og etnisk tilhøyrsle, bur fråskilt frå kvarandre, og i alle fall bur dei rike bak videoovervaka murar og med vaktselskap til å passa på. Det er ofte minimal med kontakt med menneske frå andre sosiale grupper, og den mangelfulle samhandlinga kan føra til at det ikkje oppstår nettverk mellom kulturelt og sosialt ulike menneske, og det vert difor svak gjensidig tillit mellom kulturelt og sosialt ulike menneske og sterk tillit mellom menneske som er privilegerte og like kvarandre. 
I USA vert det også skapt ein avstand mellom dei som arbeidar hardt og har rett til private pensjons- og helseforsikringar, og dei som tek imot welfare og Obamacare utan å ha betalt inn til denne helseforsikringa. Dei politiske skiljelinjene i USA vart studert i ein casestudie over TeaParty-rørsla av Vanessa Williamson, Theda Skocpol, og John Coggin (Williamson, Skocpol \& Coggin, 2011). Dette syner at det finst ei høgrerørsle som må forståast mot bakgrunnen av strukturen til den amerikanske selektive velferdspolitikken. Desse Tea-Party-folka var stort sett kvite i 6o-70-åra, og dei såg på unge menneske, svarte og innvandrarar som fiendar til det amerikanske samfunnet. Dei som deltok i Tea-Partyrørsla, meinte at Amerika vart bygd av hardarbeidande og ærlege menneske som hadde gjort seg fortente til sin velstand, og mange unge menneske, svarte og innvandrarar lurte seg unna denne samfunnspakta gjennom å ta imot Welfare-ytingar. Tea-Party-folka var ikkje motstandarar av Social Security og Medicare, noko som dei opplevde at dei hadde rett til i kraft av eigen arbeidsinnsats og innbetaling. Dei var derimot ihuga motstandarar av welfare, som gjekk til dei som ikkje hadde gjort seg fortente til utbetalingar eller ytingar gjennom eigen arbeidsinnsats og private forsikringar. Dette var mange ungdommar som levde på welfare i staden for å jobba, og det dreidde seg om mange svarte og immigrantar, slik at skiljelinjene fekk innslag av rase og etnisk opphav. Det var den nye helsereforma, Obamacare, som aktualiserte denne oppdelinga av samfunnet i dei verdige med helseforsikringar, og dei uverdige som skulle få helsetenester utan eigen innbetaling og forteneste. Dette viser ei oppløysing av den medborgarlege solidariteten, svak tillit og svak sosial kapital, noko som også bryt ned det aktive samfunnet, slik at dei demokratiske ressursane blir for svake til å løysa kollektive velferdsproblem på ein kreativ måte.

\section{Frivillig organisering, og bru-byggjande sosial kapital}

Eg støttar meg altså til eit institusjonssentrert syn på kva som genererer nettverk, sosial kapital og tillit (Rothstein 2011, s. 148-151). Dette vil også seia at vi ser at gode statlege institusjonar aukar den sosiale kapitalen 
gjennom å fremja nettverk mellom ulike menneske, og denne kvaliteten på staten og offentlege institusjonar legg mest truleg til rette for ein særskilt profil på dei frivillige organisasjonane. Høg kvalitet på statsadministrasjonen og opne og inkluderande offentlege institusjonar skaper tillit til andre personar, og denne tilliten kan også føra til at det er lettare å samarbeida med framande innanfor frivillige organisasjonar. Det er difor ein myte at ein stor stat innskrenkar aktiviteten i organisasjonslivet. Det er heller slik at i dei skandinaviske landa (og Nederland), med sterke velferdsstatar, er det ofte også markert høgare aktivitet innanfor frivillige organisasjonar enn i alle andre europeiske land, med stor del av folket som er medlemmar av frivillige organisasjonar, og med ein stor del av folket som har utført frivillig arbeid (Boje, 2008, s. 601). Det kan synast som den sosiale kapitalen og den solide tilliten som er skapt innanfor velferdsinstitusjonar, er eit av vilkåra for at dei frivillige organisasjonane er så aktive. Dette er ulikt Robert Putnams samfunnssentrerte perspektiv, som viser til at det er motsett årsaksretning, der eksistensen av frivillige organisasjonar vert rekna for eit nødvendig vilkår for eit rettferdig og effektivt demokrati.

Det er også slik at i dei skandinaviske landa, med aktive frivillige organisasjonar, vert det rapportert meir frivillig arbeid utført til støtte for familie og venner, mens til dømes i nokre land i Aust-Europa vert det utført minimalt med frivillig arbeid, både innanfor frivillige organisasjonar og frivillig innsats andsynes venner og familie. Dei skandinaviske landa har både ein utbygd velferdsstat, høg kvalitet på offentlege institusjonar, høg aktivitet innanfor frivillige organisasjonar, og rike ressursar av sosial kapital, også i privatlivet. Tabellen nedanfor viser at høge offentlege utgifter samsvarar med stor frivillig arbeidsinnsats i den yrkesaktive befolkning. Her finn ein Sverige, Noreg, Danmark og Nederland. Og i dei landa med låge offentlege utgifter finn ein ei gruppe med land med liten frivillig arbeidsinnsats. Her kan ein plassera Tsjekkia, Polen, Ungarn, Italia, Portugal og Spania. Det er altså ikkje slik som den anglosaksiske statsteorien hevdar at ein stor stat fører til liten frivillig innsats. Denne teorien er definitivt falsifisert, og det er heller slik at ein stor stat, med god kvalitet på styresettet og universelle tenesteinstitusjonar, fører til ein høg aktivitet på det frivillige arbeidet! 


\begin{tabular}{|l|l|l|}
\hline \multirow{2}{*}{$\begin{array}{l}\text { Offentlege utgifter til velferd } \\
\% \text { av BNP }\end{array}$} & \multicolumn{2}{|c|}{ Frivillig arbeidsinnsats } \\
\cline { 2 - 3 } & \multicolumn{1}{|c|}{ Stor } & \multicolumn{1}{c|}{ Liten } \\
\hline Høge & $\begin{array}{l}\text { Sverige, Noreg, Danmark, } \\
\text { Nederland }\end{array}$ & $\begin{array}{l}\text { Austerrike, Frankrike, } \\
\text { Belgia }\end{array}$ \\
\hline Låge & Storbritannia, Tyskland & $\begin{array}{l}\text { Tsjekkia, Polen, Ungarn } \\
\text { Italia, Portugal, Spania }\end{array}$ \\
\hline
\end{tabular}

Tabell 1. Samanheng mellom offentleg finansiert velferd og frivillig arbeid. (Frå Boje, 2008, s. 607).

I Sverige og Noreg finst det også særleg mange frivillige organisasjonar med ein universalistisk profil, noko som vil seia særleg organisering innanfor politiske organisasjonar, fagforeiningar, idrettslag og kulturorganisasjonar, noko som særleg bidreg til å skapa bru-byggjande sosial kapital, altså nettverk mellom menneske som er kulturelt og sosialt ulike kvarandre. Det har også vore sterk aktivitet innanfor humanitære organisasjonar, slik som Raude Kross og Norsk Folkehjelp, men engasjementet her har likevel dreia mest mot å påverka staten til å levera tenester, meir enn at desse tenestene vert produserte av organisasjonane sjølve. Danmark har hatt ein litt annan profil ved at det har vore meir vanleg at frivillige organisasjonar produserer velferdstenester, og med eit større innslag av «fri-skoler» (Boje, 2008).

USA har også hatt stor grad av frivillig organisering, men her har det vore større innslag av religiøse organisasjonar og filantropiske organisasjonar. Dette vil også seia at den sosial kapitalen som vert produsert, har meir karakter av «bonding», slik som den sosiale kapitalen internt i eit kyrkjesamfunn eller ei etnisk gruppe. Det vart skapt solidaritet, nettverk og tillit mellom relativt like menneske, og ikkje noko særleg nettverk og gjensidig tillit mellom kulturelt og sosialt ulike menneske, til dømes andre religionar og andre etniske grupper. Den skandinaviske velferdsstaten går altså i hop med sterk frivillig organisering, og ein kan seia at denne typen frivillig organisering også skaper ein stor mengde brubyggjande sosial kapital, noko som medfører at den generelle tilliten er høg i desse samfunna. Tilliten til staten og tilliten til medborgarane er svært stor i Skandinavia samanlikna med alle andre land.

I dei skandinaviske landa svarar $70-80 \%$ av folket at «folk flest er til å stola på», og 60 \% av befolkninga i Nederland meiner også det same. Det 
er forbausande kor lite generalisert tillit det er i dei fleste andre land. I Portugal, Hellas og Albania og dei fleste land i Aust-Europa svarer berre $10-30 \%$ at «folk flest er til å stola på». I Tyskland, Belgia, Austerrike, Luxemburg, Italia, Spania og Storbritannia er det 30-40 \% som svarar at «folk flest er å stola på» (Wollebæk 2013, s. 32). Det er altså rike mengder med sosial kapital som generalisert tillit i Skandinavia, der det er universelle velferdsstatar, og tilliten fell drastisk i land med svake velferdsstatar.

\section{Personleg ansvar - omsorgskvalitet}

Det er altså gode grunnar for å hevda at både offentlege institusjonar og frivillige organisasjonar bidreg til å skapa eit aktivt samfunn med rikelege mengder med bru-byggjande sosial kapital, og allmenn tillit til offentlege styresmakter og sterk tillit mellom medborgarane. Men det er likevel vanleg å hevda at offentlege barnehagar og offentleg omsorg for dei eldre fører til at omsorga blir profesjonalisert, slik at det vert mindre personleg ansvar andsynes nære familiemedlemmar. Det er vanleg å hevda, gjerne av folk frå nokre andre land, at i Noreg vert eldre menneske og barn ikkje tatt skikkeleg hand om, dei må nøya seg med kjenslekald omsorg frå framande menneske. Dette i motsetnad til samfunn der familiane har ein meir sentral posisjon, og dei eldre og barn blir sytt for på ein hjarteleg måte, og har ein sentral plass i familiane, og der spesielt visdommen til eldre menneske vert lytta til. I Noreg, heiter det i denne forteljinga, er det slik at foreldra gjev omsorga for barna frå seg til barnehagane og skulane, og gamle foreldre blir forsømt og overlatne til offentlege institusjonar.

Men realitetane er ofte annleis. Det kan vera slik at offentlege institusjonar bidreg til «differensiering» mellom ulike former for omsorg som er nærare knytte i saman i samfunn der familiane har større omsorgsansvar. Det vil seia at barn som tek seg av gamle foreldre, kan vera tyngd ned av personleg pleie slik at det å vera i lag og samtala kjem i bakgrunnen, og foreldre som har ansvar for sine barn heile tida, kan få mindre tid og overskot til leik og lesing. Det kan tenkjast at kvinner og menn som er i arbeidslivet, har ein annan kvalitet på kontakten med sine gamle foreldre som har offentleg omsorg, enn kvinner og menn som har tungt omsorgsansvar for sine skrøpelege foreldre. Det finst empiri som kan tyda på dette. 
Samanliknar ein dei mest familiesentrerte landa i Europa - Frankrike, Italia og Spania - med Danmark, som har både høgare yrkesdeltaking for kvinner og større innslag av offentlege institusjonar, finn ein eit overraskande funn: Det er ein omsnudd samanheng mellom kor ofte barn har kontakt med dei eldre foreldra, og kor intens, eller arbeidskrevjande denne kontakten er. I Danmark er det hyppig kontakt, men denne kontakten er lite arbeidsintensiv, mens i dei tre landa i sør er det vanleg med meir intensiv og arbeidskrevjande kontakt (Esping-Andersen, 2009, s. 92). Gode offentlege omsorgstenester kan føra til eit meir likestilt og gjensidig forhold som er prega av vennskap, noko som er vanskeleg dersom barna heile tida må hjelpa foreldra sine med «tung» omsorg, og dette kan også vera krenkjande for dei gamle, slik at det oppstår ein underlegen posisjon. Gode forhold mellom barn og gamle foreldre er difor lettare å få til med godt utbygde omsorgstenester, fordi då vert det rett og slett tid til å samtala i staden for å stella og vaska. Omsorga vert differensiert i likestilt samtale og nødvendig kroppspleie, det siste kan vera ubehageleg for den som gjev pleie, og nedverdigande for den som tek imot.

Det er heller ikkje slik at den omfattande offentlege innsatsen for barn, med barnehagar for nesten alle, reduserer det private ansvaret for barna. Den danske sosiologen Esping-Andersen (2009, s. 90) viser også her til ein interessant og overraskande samanheng: Fedrar med barn i barnehagen deltek med fleire timar med omsorg for barna enn det fedrar gjer der barna ikkje er i barnehage, altså er heime med mora eller annan omsorgsperson. Det synest som at profesjonell omsorg og pedagogisk styrt læring i barnehagane fører til at fedrar kan få meir tid og ressursar til å vera i lag med barna sine.

\section{Avslutning}

Denne artikkelen kan også lesast som eit forsvarsskrift for den norske og skandinaviske samfunnsmodellen. Eg har forsøkt å visa til at det kan eksistera ein indre slektskap mellom den demokratiske staten og det aktive samfunnet, med breie folkerørsler, individuell fridom og omfattande tillit mellom medborgarane og tillit til statlege institusjonar. Dei nordiske landa har hatt mellom dei mest demokratiske statane i verda, 
og dei mest aktive samfunna og folkerørslene. Historisk sett vaks det fram ein demokratisk stat i takt med embetsmannsstaten, og to ulike grupper av embetsmenn som i grunnen utfylte kvarandre i moderniseringa av Noreg. Både juristane og dei lutherske prestane var inspirerte av opplysning, fornuft og sosial liberalisme, heller enn tradisjon og hevdvunne stands- og klaninteresser. Juristane var viktige i framveksten av rettssaten og utviklinga av dei individuelle rettane. Dei lutherske prestane hadde nær kontakt med folket over heile landet, både når det galdt undervisning i katekisme og opplæring i praktisk kunnskap om jordbruket. Desse lutherske embetsmennene vart difor kalla «potetprestar». Den protestantiske statskyrkja bidrog også til ein religiøs individualisme, som vart eit kulturelt vilkår for den skandinaviske statsindividualismen. Den moderne norske staten vart også forma av ulike folkerørsler, eller eit aktivt og sjølvstendig samfunn, som etablerte eit mønster som også vart overtatt av sosialdemokratiet, i samspelet mellom ein sterk embetsstat og «folkerørsler» med sterk lokal organisering.

Denne demokratiseringa av staten kan også tolkast som at demokrati og offentlege institusjonar er eit vilkår for individuell fridom forstått som fridom frå avhengigheit. Den norske ekteskapslovgjevinga var tufta på individuelle kontraktar i sterkare grad enn i mange andre europeiske land. Dette førte til at ekteskapet i stor grad var ei pakt mellom ein mann og ei kvinne, heller enn ein avtale mellom to slekter. Slik sett vart særleg kvinnene meir sjølvstendige og meir uavhengige av foreldra, slekta og mennene.

Utbygginga av den norske velferdsstaten førte det einskilde individet direkte i kontakt med staten. Dette har blitt kalla «statsindividualisme» (som altså først vart utvikla innanfor den lutherske statskyrkja), fordi velferdsstaten har utvida den individuelle fridomen, slik at den enkelte med individuelle pensjonar har vorten mindre avhengig av marknaden, arbeidsgjevar og slekta, og kvinnene vart mindre avhengige av mennene. Det var ein samanheng mellom demokrati, velferdsstat, sosial likskap og individuell fridom. I mange andre europeiske nasjonar vart pensjonsytingane formidla av familien, yrke, arbeidsplassen, fagforeininga, og i marknadsretta velferdsstatar vart pensjonane betalte ut av private forsikringsselskap. 
Eg har også argumentert for at det er ein nær samanheng mellom demokrati og velferdsstat, fordi folk har interesse av å vera engasjerte i politiske prosessar så lenge velferdspolitikken er universell og vedkjem alle. Demokratiet har slik ein bruksverdi og eit substansielt innhald, noko som mellom andre Habermas har peika på, og dette medfører også at diskusjonar i den offentlege sfære ofte handlar om velferdspolitikk. På den andre sida vert grunnane til å engasjera seg politisk svekte i selektive velferdsstatar, fordi velferdspolitikken berre er retta mot dei med særskilte behov, og desse vil heller ikkje vedkjenna seg at dei får denne nedverdigande stønaden.

Eit bidrag i denne artikkelen er at eg brukar omgrepa sivilt samfunn og sosial kapital også for å skildra vesentlege trekk ved offentlege institusjonar. Ein norsk skule, ein barnehage eller eit sjukehus er ein del av det sivile samfunnet, fordi desse institusjonane er opne for alle. Offentlege institusjonar har også eit viktig aspekt av det sivile samfunnet, til dømes universalismen, den formelle likestillinga og dei upartiske tenestene. Offentlege institusjonar bidreg til at ulike menneske samhandlar, slik at det vert danna nettverk mellom menneske frå ulike klassar, religionar, etniske grupper og livsstilar. Offentlege institusjonar saman med visse typar frivillige organisasjonar som er opne for dei fleste, skaper nettverk som er bru-byggjande sosial kapital. Andre typar frivillige institusjonar, til dømes Jehovas vitne eller Profetens Ummah, kan neppe seiast å vera ein del av det sivile samfunnet.

\section{Referansar}

Alexander, J. (2006). The Civil Sphere. Oxford: Oxford University Press.

Bauman, Z. (1998). Work, consumerism, and the new poor. Buckingham: Open University Press.

Boje, T. (2008).Velfærdsstat og civilsamfund: De nordiske lande i komparativt perspektiv. Tidsskrift for samfunnsforskning, 49(4), 595-611. Henta frå https:// www.idunn.no/tfs/2008/o4/velferdsstat_og_civilsamfund_de_nordiske_lande_ ikomparativt_pe

Bourdieu, P. (1998). Acts of Resistance. Against the New Myths of our Time. Cambridge: Polity Press.

Esping-Andersen, G. (1985). Politics against Markets: The Social Democratic Road to Power. Princeton, New Jersey: Princeton University Press. 
Esping-Andersen, G. (1990), The Three Worlds of Welfare Capitalism. London: Polity Press.

Esping-Andersen, G. (2009). The incomplete revolution. Cambridge: Polity Press.

Fraser, N. (2000). Rethinking Recognition. New Left Review, 3, 107-120.

Habermas, J. (2001). Den postnationella konstellationen. Göteborg: Bokförlaget Daidalos.

Mann, M. (2013). The sources of social power. Volume 4: Globalizations, 1945-2011. Cambridge: Cambridge University Press.

Møen, A. (1999). Det sivile samfunn og andre samfunnsområde. I A. Møen \& R. Slaattelid (Red.). Det sivile samfunn. Oppseding, verdiar og offentleg meining (s. 23-51). Oslo: Aschehoug forlag.

Putnam, R.D. (2007). E Pluribus Unum: Diversity and Community in the Twenty-first Century. The 2006 Johan Skytte Prize Lecture. Scandinavian Political Studies, 3o(2), 137-174. https://doi.org/10.1111/j.1467-9477.2007.00176.x

Rothstein, B. (2011). Quality of Government: Corruption, Social Trust, and Inequality in International Perspective. Chicago: University of Chicago Press.

Skirbekk, G. (2010). Norsk og moderne. Oslo: Res Publica.

Selle, P. (2008). Forståinga av sivilsamfunnet. Er det berre opp til augo som ser? Tidsskrift for samfunnsforskning, 49(4), 613-628. Henta frå https://www.idunn.no/ tfs/2008/o4/forstainga_av_sivilsamfunnet_er_det_berre_opp_til_augo_som_ser

Skinner, Q. (2011). Staten og friheten. Oslo: Res Publica.

Stråth, B. (2016). När var demokratin?. Historisk tidsskrift, 95, 269-291. Hentet fra https://www.idunn.no/ht/2016/02/nr_var_demokratin

Trägårdh, L. (2008). Det civila samhällets karriär som vetenskapligt och politiskt begrepp i Sverige. Tidsskrift for samfunnsforskning, 49(4), 575-591. Henta frå https://www.idunn.no/tfs/2008/o4/det_civila_samhllets_karrir_som_ vetenskapligt_och_politiskt_begrepp_i

Wacquant, L. (2014). Marginalisering, etnisitet og straff i den nyliberale byen: en analytisk kartografi. Agora, 31(03-04), 205-233. Henta frå https://www.idunn.no/ agora/2014/03-04/marginalisering_etnisitet_og_straff_i_den_nyliberale_byen

Wagner, P. (2012). Modernity. Understanding the Present. Cambridge: Polity Press.

Wilkinson, R. \& Pickett, K. (2012). Ulikhetens pris. Oslo: Res Publica.

Williamson, V., Skocpol, T. \& Coggin, J. (2011). The Tea Party and the Remaking of Republican Conservatism. Perspectives on Politics, 9(1), 25-43. https://doi. org/10.1017/S153759271000407X

Wollebæk, D. (2013). Religion og sosial kapital: Hva viser internasjonale spørreundersøkelser? (Rapport Sivilsenteret 4/13). 


\title{
ARTIKKEL 3
}

\section{Myten om velferdsavhengighet}

\author{
Kristoffer Chelsom Vogt, førsteamanuensis, Universitetet $i$ \\ Bergen, Sosiologisk institutt
}

\section{Abstract}

Title: The Myth of Welfare Dependency. Summary: The myth of welfare dependency has long historical roots and is influential in both policy and research. The central idea is that receiving welfare benefits decreases people's motivation for work and fosters a culture of dependency. The myth originates in an Anglo-American context but is also evident in a Nordic context. Nordic welfare states, with their comparatively high levels of benefits, are presumably especially at risk of encouraging welfare dependency. This article questions the myth of welfare dependency, by presenting a life-course perspective that directs our attention to relations between historical developments and individual life-course processes. Viewed from a life-course perspective, it becomes clear that the myth of welfare dependency is based upon a number of problematic premises: an individualistic and static conception of lives and relationships, a narrowly defined concept of welfare, and on several misconceptions of how welfare state policies, especially of the Nordic variety, function in practice. The dichotomy of dependence and independence upon which the myth rests is untenable when confronted with empirical lifecourse research, and has highly-skewed implications in terms of both gender and social class.

Keywords: Welfare, welfare dependency, life-course perspective, dependence and independence

\section{Introduksjon}

Myten om velferdsavhengighet gjør seg gjeldende både i offentlig debatt og i forskning, ikke bare gjennom selve ordet 'velferdsavhengighet' men også gjennom formuleringer som at folk blir 'avhengig av sosiale stønader', og begreper som 'trygdefelle'. Framstående forskere har ment at det er særlig stor fare for velferdsavhengighet i nordiske velferdsstater fordi vi her har relativt sett generøse velferdsytelser (Giddens, 1998). Begrepet

Sitering av denne artikkelen: Vogt, K.C. (2018). Myten om velferdsavhengighet. I K. Christensen \& L.J. Syltevik (Red.), Myter om velferd og velferdsstaten (s. 59-73). Oslo: Cappelen Damm Akademisk. https://doi.org/10.23865/noasp.47.ch3

Lisens: CC BY-NC 4.0 
velferdsavhengighet viser ikke, slik man kanskje kunne tenke seg, til at velferd er noe alle er avhengige av. Det viser snarere til avhengighet i den engelske betydningen 'addiction', og forbindes særlig med voksne utenfor arbeidslivet som mottar offentlige stønader. Den sentrale idé bak begrepet er at ens karakter endres når en går på velferdsytelser gjennom befatning med en moralsk korrumperende avhengighetskultur, og at en dermed gradvis mister lysten til å arbeide. Jo mer generøs en ytelse er, jo mer avhengighetsskapende antas den å være. Frykt for velferdsavhengighet springer ut av angloamerikansk kontekst. Begrepet fikk først gjennomslag på 8o-tallet i USA og har siden den gang blitt brukt tilå rettferdiggjøre kutt i velferdsprogrammer i en rekke nasjonale kontekster. ${ }^{1}$

Jeg vil i denne artikkelen gi et bidrag til en sosiologisk forståelse av myten om velferdsavhengighet. Jeg argumenterer for at denne er basert på en individualistisk og statisk forståelse av menneskers liv og relasjoner, på et snevert begrep om hva velferd er, og på grunnleggende misforståelser av hvordan velferdsstater fungerer. Myten om velferdsavhengighet kan bidra til et feilaktig bilde av befolkningen som delt i to; bestående av noen som bidrar, og noen som snylter. Den ladete dikotomien mellom avhengighet og selvstendighet, som myten om velferdsavhengighet bygger på, er uholdbar når den konfronteres med empirisk basert kunnskap om menneskers livsløp, og den slår også skjevt ut med hensyn til både kjønn og sosial klasse.

\section{Hva er velferd?}

For å forstå begrepet velferdsavhengighet er det nødvendig å dele det opp i ordets to bestanddeler: velferd og avhengighet. Begrepet velferd kan spores til gammelnorsk på 1300-tallet og betydde da «måtte din videre ferd gjennom dette liv gå godt», og har senere blitt et engelsk lånord (Øyen, 1983, s. 112). Det var særlig på 70-tallet mye diskusjon om selve velferdsbegrepet, der noen forskere vektla ressurser, og andre vektla ulike typer menneskelige behov (Allardt, 1978; Johansson, 1977). En bred oppsummering kunne være at velferd viser til de betingelser som legger til rette for at det skal gå folk godt gjennom livet, at de kan 'fare vel' gjennom livet. Ordet velferd har nok også generelt mer positive konnotasjoner i Norge 
enn i en del andre land. I USA brukes for eksempel «welfare» i en mer avgrenset forstand, om ulike former for behovsprøvd sosialhjelp, og har en mer negativ klang.

Om man skal tenke klart rundt spørsmål om velferd, finnes det noen grunnleggende begreper (tankeredskaper) som kan være nyttige. Den såkalte velferdstrekanten viser til at det grunnleggende sett finnes tre kilder til velferd: stat, marked og sivilsamfunn (herunder familie). Disse tre leverandørene av velferd samspiller i særegne kombinasjoner i ulike land, ulike historiske perioder, og i ulike faser av livsløpet. En annen viktig typologi i velferdsforskningen er skillet mellom overføringer og tjenester (Stamsø, 2017, s. 139). Med disse typologiene etablert kan vi konstatere at begrepet velferdsavhengighet særlig brukes om velferd finansiert av staten, og da nærmere bestemt om overføringer til voksne utenfor arbeidslivet (Fraser \& Gordon, 1994). Et ensidig fokus på overføringer i denne kategorien fremstår som særlig besynderlig i nordiske velferdsstater, som siden 30-tallet har vært kjennetegnet av støtte gjennom tildeling av tjenester (Stamsø, 2017, s. 140). Gratis eller rimelige offentlige tjenester fremheves ofte som de nordiske velferdsstaters mest definerende særtrekk (Kvist, Fritzell, Hvinden \& Kangas 2011, s. 9). De siste tiårene kan det se ut til at myten om velferdsavhengighet også preger tenkningen om velferdstjenester, gjennom økt fokus på uavhengighet og rehabilitering, og frykt for lært hjelpeløshet (Aspinal, Glasby, Rostgaard, Tuntland, \& Westendorp 2016; Christensen, 2009).

\section{Avhengighetsbegrepets historiske bakgrunn}

For å forstå begrepet avhengighet er det nyttig å ta et historisk perspektiv. Amerikanske forskere har gjort grundige studier av dette ordets historie (Fraser \& Gordon, 1994). I førindustriell tid betydde det å være 'dependent' ganske enkelt at man jobbet for noen andre, hvilket var en svært utbredt situasjon. I takt med industrialiseringen ble husholdet og produksjonen skilt, og fokuset på lønnsarbeid ble gradvis sterkere. Avhengighet ble nå ikke lenger sett som en relasjon, slik det tidligere hadde blitt, men som et avvikende karaktertrekk som preget slaver, tiggere og kvinner. Ulønnede aktiviteter var fremdeles helt nødvendige, men de ble 
i økende grad usynliggjort ved å bli regnet som ikke-arbeid. Den kjønnede arbeidsdelingen gjorde at det var kvinner som tok seg av brorparten av dette ulønnede arbeidet. Som hovedregel ble dermed menn plassert som uavhengige, mens kvinner ble sett som 'dependents'. Det var i denne overgangsperioden omkring midten av 1800-tallet at ideen om individuell uavhengighet fikk fotfeste. Det var også her dagens ideal om at selvstendighet (independence) skal og kan sikres gjennom lønnsarbeid, slo rot. Begrepet avhengighet ble dermed allerede i industrialiseringens tidlige fase individualisert, stigmatisert og feminisert.

Fra 1980-tallet og fremover oppsto vår tids variant av myten om velferdsavhengighet. Dette skjedde først i USA gjennom forskning og debatt om 'welfare dependence'. Bakteppet var at de offentlige budsjettene strammet seg til fra andre halvdel av 1970-tallet og fremover, blant annet på grunn av økende arbeidsledighet. En medvirkende faktor var at afroamerikanere og arbeidsmigranter hadde fătt tilgang til velferdsytelser etter borgerrettsbevegelsens seiere fra 6o-tallet. Afroamerikanske alenemødre skulle komme til å bli ikonet på 'welfare dependence', og forestillinger om velferdsavhengige 'welfare queens' bidro blant annet til å legitimere Clinton-administrasjonens kutt i velferdsytelser til barnefamilier i 1996 (T. Frank 2016, s. 288). I tiårene siden den gang har ideen om velferdsavhengighet spredd seg til andre land, og bidratt til å legitimere tilsvarende kutt i velferdsytelser der.

Bekymring for velferdsavhengighet kom til Norge på 1990-tallet og har blitt gradvis forsterket fram mot i dag gjennom formuleringer om at folk blir 'avhengig av sosiale stønader' og havner i en 'trygdefelle' ved å motta ytelser. Landet ble konfrontert med vekst i offentlige utgifter og en tverrpolitisk frykt for at staten gjennom såkalt snillisme sto i fare for å «sy puter under armene» på folk (Gerhardsen, 1991). I denne særnorske innrammingen av en mer utbredt tematikk står «snillisme» i motsetning til «selvstendighet», som tilsynelatende skal innebære å ikke ligge andre til last (Gullestad, 1996, s. 29). Myten om velferdsavhengighet har bidratt til oppfatninger om at dersom ytelser er for generøse, vil ikke folk ønske å arbeide. I tråd med denne tankegangen har Norge, likhet med de andre nordiske land, de siste tiårene senket satsene på sosialstønad (den viktigste stønaden som $i k k e$ er knyttet til tidligere lønnsarbeid), og generelt 
styrket aktivitetskrav med mål om å skape insentiver for å jobbe og dermed motvirke velferdsavhengighet. Resultatet er blant annet at sosialstønad, velferdsstatens 'gulv', nå ikke er noe høyere i nordiske land enn i andre europeiske land (Dølvik, Fløtten, Hippe \& Jordfald, 2014; Kvist et al., 2011).

\section{Tidsdimensjonen og mytens sviktende premisser}

Velferdsstater driver med to former for redistribusjon: vertikal og horisontal (Kvist, 2015). Det var vertikal redistribusjon Robin Hood drev med i Sherwood-skogen, om enn i liten skala og med tvilsomme metoder. Det meste av det velferdsstater driver med, er horisontal redistribusjon; de overfører ressurser mellom mennesker i ulike livsfaser, livsfaser som alle forventes å gå gjennom (Kohli, 2015; Kvist, 2015). Det ligger en slags «intergenerasjonell kontrakt» til grunn for alle velferdsstater, gjennom at kostnadene for å ta vare på barn og eldre blir kollektivisert, om enn i svært ulik grad i ulike land (Folbre \& Wolf, 2013). Den grunnleggende tanken er at folk i arbeidsfør alder finansierer ytelser og tjenester som mennesker i alle aldere drar nytte av. De som betaler skatt, betaler både for noe som de har nytt godt av (f.eks. gratis skolegang, fungerende institusjoner), noe som de nyter godt av i dag (f.eks. parker, sykepenger eller statssubsidiert kultur), og for noe som de selv kan komme til å trenge i fremtiden (helsehjelp, trygd, pensjon, hjemmehjelp osv.). Myten om velferdsavhengighet kan bidra til at denne typen horisontal redistribusjon, som er basert på komplekse intergenerasjonelle og intersituasjonelle dynamikker, overses.

I boken Good Times Bad Times: Welfare Myths of Us and Them beskriver den britiske forskeren John Hills (2015) hvordan begrepet velferdsavhengighet henger sammen med bildet av samfunnet som bestående av to grupper: de som bidrar, og de som snylter. Han sier at det i England er en utbredt forestilling om at velferdsstaten opererer nettopp som en slags Robin Hood, som tar penger fra de rike og gir til de fattige. Hills argumenterer overbevisende for at et slikt statisk bilde av befolkningen er grunnleggende misforstått. Han viser at det meste av velferdsstatens 
midler går til formål som alle nyter godt av, og de fleste mottakere er ute av arbeidslivet bare i korte perioder før de kommer inn igjen. Bildet av velferdsstaten som en Robin Hood som først og fremst omfordeler mellom to statiske deler av befolkningen er, om noe, enda mer misvisende i Norge enn i England. Nordiske land er kjent for å innrette både tjenester og ytelser med sikte på å få folk ut i arbeid, og tilbake i arbeid om de skulle falle ut (Kvist et al., 2011). Dette har vært en vellykket strategi om en skal dømme ut fra Norges sysselsettingsgrad, som er i verdensklasse, særlig for kvinner (Esping-Andersen, 2009).

Norske velferdsforskere var tidlig ute med å empirisk avvise myten om velferdsavhengighet, ved å analysere trygdeforløp gjennom bruk av registerdata. Hansen (1996, s. 3) konstaterte, som Kolberg 15 år tidligere, at «situasjonsanalyser» kan bidra til at den vesentlige «tidsdimensjonen» blir oversett. Om en overser tidsdimensjonen, risikerer en å gå glipp av flyten inn og ut av ulike ytelser. Eller, sagt med andre ord, så risikerer en å «fryse» liv som i realiteten er i bevegelse (Hagestad. 2009, s. 397). Påstander om at jo mer universelle og generøse ytelser er, jo lenger vil folk gå på dem - jo mer avhengig blir de - er også tilbakevist basert på grunnlag av europeiske sammenlikninger av sosialhjelpsmottak (Saraceno, 2002, s. 244). Sjansen for å komme inn i arbeid blir ikke mindre av å motta generøse ytelser - snarere tvert imot.

Det stadig vanligere uttrykket «havner på NAV» er i seg selv talende for den statiske forståelsen av velferdsstaten som ligger til grunn for myten om velferdsavhengighet. NAV ble opprettet i 2006 gjennom en sammenslåing av flere tidligere etater, og «naver» ble kåret til årets nyord i 2012. Siden den gang har det vært tiltakende bekymring over at stadig flere unge «havner på $\mathrm{NAV}$. $^{2}$ I diskusjoner om slike temaer har det versert flere misvisende oppfatninger om velferdsutviklingen. Det har for eksempel etablert seg en «sannhet» om at en stadig større andel mennesker i yrkesaktiv alder lever av trygd og ikke av arbeidsinntekter. Om en gjør nærmere analyser av endringer i sysselsettings- og trygdeårsverk de siste 20 årene, blir det imidlertid klart at denne bekymringen har svakt empirisk grunnlag (Terum \& Hatland, 2014). De siste tiårs økning av unge uføre skyldes i stor grad markante nedganger i dødelighet blant unge med psykisk utviklingshemning, medfødte misdannelser og kromosomavvik 
(Brage \& Thune, 2015, s. 42; Bragstad, 2018, s. 71). Et tilsvarende nyanserende bilde tegnes ved en samlet gjennomgang av alle velferdsstatens livsoppholdsytelser fra 1994 til 2016. Det er en avtakende trend i bruk av livsoppholdsytelser siden 2003, og «den sterkeste nedgangen finner vi blant de som er under 30» (Kann \& Sutterud, 2017, s. 66). Særlig den yngste delen av befolkningen bruker NAV-ytelser «i stadig mindre grad» (Kann \& Sutterud, 2017, s. 65).

Et Dagbladet-oppslag fra 2015 illustrerer sammenhengen mellom myten om velferdsavhengighet og et statisk syn på velferdsstatens fungering (Landsend \& Monsen, 2015a). Som en del av en større serie om «Unge navere» publiserte Dagbladet i 2015 en forsidehistorie og en videoreportasje om en ung mann fra Notodden som ikke var i jobb. Den aktuelle unge mannen hadde ifølge ham selv «ikke viljen til å arbeide» og var godt fornøyd med å motta ytelser fra NAV ettersom han da kunne bruke tiden på det han ønsket: å mekke på biler og mopeder. Oppslaget vakte storm og harme i avisenes kommentarfelt. Noen måneder senere kontaktet den unge mannen Dagbladet for å få en slutt på trakasserende anrop på telefonen. Han kunne informere om at han hadde fătt jobb gjennom NAV og nå gikk i lære for å bli anleggsmaskinfører. Dagbladet publiserte da en ny og mindre sak, som fikk langt mindre oppmerksomhet, under overskriften «'Jeg vil nave’ sang Kjetil. Nå har han fått seg jobb. Slik gikk det med de unge 'naverne'» (Landsend \& Monsen, 2015b). ${ }^{3}$

Så hvilken gruppe tilhører han egentlig, denne «naveren fra Notodden»? De som bidrar til velferdsstaten, eller de som nyter godt av dens overføringer og tjenester? Svaret er at det kommer an på hvilket tidspunkt du treffer ham på, og at denne typen kategoriseringsforsøk derfor er meningsløse. Da «naveren fra Notodden» fikk jobb, kom han i gang med horisontal redistribusjon, med å samfinansiere velferdsstaten, deriblant NAV. Gjennom skatt av sin inntekt distribuerer han nå penger til sitt tidligere seg, eller mer presist, til andre som har behov for ytelser og tjenester fra NAV for å komme seg inn i arbeidslivet. Dette eksempelet illustrerer hvordan spørsmål om velferdsavhengighet, enten det gjelder unge «navere» eller hjemmeværende småbarnsmødre med innvandrerbakgrunn, straks blir mer nyanserte og kompliserte dersom en evner å ta spørsmål om tid og livsløp med i betraktning. 


\section{Er selvstendighet mulig?}

Myten om velferdsavhengighet henger som antydet ovenfor sammen med en utbredt og gammel forestilling om at en gjennom lønnsarbeid kan bli «selvstendig». Den er dermed basert på det vi kan kalle et illusorisk referansepunkt. For hva vil det egentlig si å være selvstendig, og er det strengt tatt mulig i en kompleks moderne verden der det å være selvforsynt er blitt fullstendig uaktuelt? ${ }^{4}$

Som vi så ovenfor, inviterer myten om velferdsavhengighet til at visse former for velferd (særlig overføringer til voksne utenfor arbeidslivet) stigmatiseres, samtidig som de former for velferd som de fleste nyter godt av (utdanning, helsehjelp, skattefradrag, familieomsorg osv.), unnslipper betegnelsen velferd overhodet. Resultatet kan bli at den individuelle selvstendigheten til privilegerte samfunnsgrupper overvurderes. I en amerikansk studie av familie-hjelp stilte sosiologen Karen Hansen (2004, s. 2) det skarpe spørsmålet: «What enables them to think they are independent when they actually receive a lot of support?» Til syvende og sist er det kanskje akkurat dette myten om velferdsavhengighet brukes til? Den hjelper mange av oss til å tro at vi er selvstendige, på tross av at vi mottar mye hjelp og støtte, og dermed til å gi oss en følelse av selv-verd. De britiske forskerne Kittay og Feder har formulert samme poeng på en annen måte. De hevder ganske enkelt at «independence results from invisible or unacknowledged dependencies» (sitert i Bowlby, Gregory \& McKie, 2010, s. 43). Spørsmål om oversette forbindelser og relasjoner har lenge stått sentralt i nordisk velferdsforskning gjennom arbeidene til Kari Wærness. I en artikkel fra 1978 omtalte hun kvinners ulønnede omsorgsarbeid som «den usynlig velferdsstaten» (Wærness, 1978). Med Wærness' begrep kan vi kanskje si at myten om velferdsavhengighet bidrar nettopp til at noen former for velferd stigmatiseres, mens andre blir usynliggjort.

Kritikere av myten om velferdsavhengighet, og, mer generelt, kritikere av dikotomien mellom avhengighet og selvstendighet, retter oppmerksomhet mot gjensidig avhengighet (interdependence) (Bowlby et al., 2010; Fraser \& Gordon, 1994; Hagestad, 2009). Et livsløpsperspektiv er et egnet utgangspunkt for å forstå denne gjensidige avhengigheten. Livsløpsperspektivet er en tverrdisiplinær tilnærming til samfunnsvitenskap som er fundert i amerikansk pragmatisme, blant annet i George Herbert Meads teori om 
selvet som sosialt og prosessuelt, og er en grunnleggende sett kontekstualistisk tilnærming til studiet av menneskelig liv (Elder, Kirkpatrick Johnson \& Crosnoe, 2003). Livsløpsforskning retter oppmerksomheten nettopp mot sammenhengene mellom større historisk-institusjonelle forhold og enkeltmenneskers livsløpsprosesser. Et av de grunnleggende prinsippene i livsløpsforskning er prinsippet om sammenvevde liv (linked lives) (Elder et al., 2003). Gjennom et livsløpsperspektiv kan en studere de komplekse sekvenser av tilstander og roller som individer gjennomgår i løpet av livet, og i løpet av en og samme dag. Det viser da raskt at en inndeling av befolkningen i de velferdsavhengige og de selvstendige er grovt overforenklende. Livene til menn, kvinner, barn, foreldre, besteforeldre, ansatte, arbeidsgivere, naboer og venner er sammenvevd på en rekke intrikate måter. Er man for eksempel å regne som selvstendig om man arbeider 100 prosent, gjør bruk av en utdanning som en i stor grad har fått dekket av staten, og samtidig får økonomisk hjelp fra familien? Selv det enkleste eksempel illustrerer at det ganske snart melder seg vanskelige vurderingsspørsmål dersom en er villig til å ta kunnskap om menneskers livsløp med i betraktning. Et livsløpsperspektiv er, gjennom å rette oppmerksomhet mot tidsdimensjonen, velegnet til å bryte ned dikotomien mellom avhengighet og selvstendighet som underbygger myten om velferdsavhengighet.

\section{Myten i maktperspektiv}

Myten om velferdsavhengighet kunne kanskje vært harmløs om den ikke hadde slått skjevt ut sosialt. Dikotomien mellom velferdsavhengighet og individuell uavhengighet har alltid vært innvevd i maktrelasjoner. Det at myten om velferdsavhengighet overser alle andre former for velferd enn den som overføres fra stat/kommune til voksne utenfor arbeidsmarkedet, har ulike konsekvenser for forskjellige samfunnsgrupper. Det fører potensielt, som allerede påpekt, til at visse former for velferd stigmatiseres ved at de forbindes med moralsk forfall og dovenhet. En annen og mindre påaktet virkning kan være at andre samfunnsgrupper inviteres til å betrakte seg som selvstendige. Da vi drøftet myten om velferdsavhengighet ut fra velferdstrekanten, så vi at avhengighet av velferd levert av markedet (gjennom en god lønn eller en 
god kontorstol), eller velferd en får gjennom sivilsamfunnet (gjennom en stor arv eller nær gratis fritidsaktiviteter for sine barn) ikke regnes som velferdsavhengighet. Myten kan dermed føre til at selvstendighetens æresmerke utdeles til de som får velferd fra markedet eller sivilsamfunnet, eller gjennom andre former for offentlig velferd. De som tar lang statsfinansiert utdanning, får store skattefradrag som boligeier, eller mottar pensjon lenge som et resultat av sin lange levealder, blir ikke regnet som velferdsavhengige. Det overordnede resultatet av myten er dermed at privilegerte samfunnsgruppers selvstendighet blir overvurdert, og at de mange måtene som også disse nyter godt av velferdsstaten på, blir usynliggjort. På den andre siden kan myten om velferdsavhengighet, som allerede antydet ovenfor, bidra til negativ omtale av samfunnets minst privilegerte grupper. Ut fra en sammenlikning av retorikk knyttet til sosial ulikhet på 1800-tallet og 2000-tallet, konkluderer den franske økonomen Thomas Piketty (2014) med at «modern meritocratic society ... is much harder on the losers» (s. 416), fordi fattigdom i dag oftere blir forklart med henvisning til individuell adferd, lav produktivitet og sviktende karakterstyrke. Kort sagt er det grunnlag for å hevde at myten om velferdsavhengighet tjener visse samfunnsgrupper mer enn andre, og at den slik sett fungerer som en ideologi; den utgjør en misvisende virkelighetsbeskrivelse som bidrar til å legitimere den foreliggende samfunnsorden (Mannheim, 1936; Vogt, 2016).

Omtaler av samfunnets mest hjelpetrengende har lenge stått i sterk kontrast til fremstillingen av samfunnets mer privilegerte grupper. Skepsis mot snyltere har lenge hatt den egenskap at det effektivt kan få samfunnets minst privilegerte grupper til å «vende seg mot hverandre, heller enn systemet» (Sennett \& Cobb, 1972). Fattige i Storbritannia blir stigmatisert som avhengige av staten, mens lave skatterater og systematisk skatteunndragelse ved hjelp av store revisjonsselskaper i all stillhet fungerer som subsidier for de rike (Jones, 2014, s. 201). Den amerikanske økonomen Joseph Stiglitz (2012) bruker begrepet «socialism for the rich» som beskrivelse av det at mange land de siste tiårene har brukt stadig mer av fellesskapets ressurser på å tilrettelegge for at de rike skal bli enda rikere. Ikke bare er de velstående like avhengige av velferd som andre, de ender opp med stadig mer av velferdsstatenes krympende budsjetter. 


\section{Avslutning}

Oppsummert kan vi si at myten om velferdsavhengighet er basert på en individualistisk og statisk forståelse av menneskers liv og relasjoner, og på et snevert begrep om hva velferd er. Den beskriver verden som om det bare eksisterer én type velferd - pengeoverføringer til voksne utenfor arbeidslivet - og inviterer dermed til at andre kilder til velferd (markedet, sivilsamfunnet, familien) og andre former for velferd (f.eks. helsetjenester, avlastning, utdanning) blir oversett. Myten om velferdsavhengighet forleder derfor til grunnleggende misforståelser av hvordan velferdsstater fungerer. Erfaringer fra andre land (særlig USA og Storbritannia) tilsier at myten om velferdsavhengighet kan bidra til å gi selve velferdsbegrepet en negativ klang og legitimere et lavt stønadsnivå.

Sosiologer har siden Durkheim (1995/1912) vært oppmerksom på at ikke bare urfolk, men også moderne mennesker trenger felles myter for å leve, for å skape mening, og for å klare å samarbeide. Enkelte har sågar fremstilt det å «avkle» slike myter som sosiologiens kjerneoppgave (Elias 1970, s. 50). Men hvorfor skal vi som sosiologer bry oss med å stille spørsmål ved myter? Når noen oppfatter seg som «selvstendig» og andre som «velferdsavhengig», er ikke det ganske harmløst? Kan ikke vedkommende få beholde den illusjonen? Nei. Selvstendighet i betydningen uavhengighet fra alle de tre leverandørene av velferd (staten, markedet og sivilsamfunnet) kan ikke oppnås i moderne samfunn basert på spesialisert arbeidsdeling. Selvstendighet kan derimot innvilges i ulik grad, og til ulike grupper, av forskjellige samfunnsinstitusjoner. Selve ordet «selvstendighet» er en hedersbetegnelse som ulike samfunnsgrupper i større og mindre grad lykkes i å gjøre krav på. I et ulikhetsperspektiv er det mye som tyder på at myten om velferdsavhengighet vil bli stadig viktigere i årene fremover. Forestillinger om at velferdsytelser i seg selv skaper avhengighet, kan for eksempel skimtes bak den nylige innføringen av aktivitetskrav for mottak av sosialhjelp.

Dersom sosiologer eller andre ikke gjør oppmerksom på hvilke myter som ligger til grunn for forskjellige institusjonelle ordninger og endringer, forblir vi uvitende om vesentlige samfunnsforhold. En risikerer da jevne steg i retning av den repressive politikken som ble ført overfor fattige 
på siste del av 180o-tallet (se Ulvund, 2002). Den gode nyheten er at det å pirke i virkningsfulle myter kan ha høyst reelle konsekvenser. Som Robert Frank (2016) påpeker i sin bok Success and Luck: Good Fortune and the Myth of Meritocracy finnes det stadig mer forskning som viser at «even small shifts in cognitive framing can dramatically transform how people think» (s. 105).

\section{Sluttnoter}

1. Se Hansen (2008) og Dahl og Lorentzen (2003) for detaljerte gjennomganger av den til dels svært tekniske faglitteraturen om velferdsavhengighet. Se også Syltevik (2006) om konsekvensene av endret politikk overfor enslige forsørgere.

2. Et søk i medieovervåkningstjenesten Atekst Retriever viser en jevn økning i bruken av uttrykket «havner på NAV», særlig siden 2013.

3. Et tilsvarende eksempel fra Danmark, i Berlingske Tidendes sak «Husker du Dovne Robert? Nu har hans arbejdsliv taget en overraskende drejning» (Fahnøe, 2017). Se også Dencker-Larsen og Lundbergs (2016) studie av stereotypiske fremstillinger av velferdsbrukere i Norge og Danmark.'

4. Hele velferdsstaten kan betraktes som et forsøk på å motvirke og kompensere for den vekst $\mathrm{i}$ avhengighet som oppsto ved økt arbeidsdeling/spesialisering i takt med moderniseringen av samfunnet (Titmuss, 1958, s. 44, med referanse til Durkheim).

\section{Referanser}

Allardt, E. (1978). Dimensions of welfare in a comparative Scandinavian study. Acta Sociologica, 19(3): 227-239. https://doi.org/10.1177/o00169937601900302

Aspinal, F., Glasby, J., Rostgaard, T., Tuntland, H. \& Westendorp, Rudi G.J. (2016).

New horizons: Reablement - supporting older people towards independence. Age and Ageing, 45(5): 574-578. https://doi.org/10.1093/ageing/afwo94

Bowlby, S., Gregory, S. \& McKie, L. (2010). Care and interdependency. I S. Bowlby, S. Gregory \& L. McKie (Red.), Relationships and Resources: Interdependency and Care Over the Lifecourse (s. 38-53). Florence, KY, USA: Routledge.

Brage, S. \& Thune, O. (2015). Ung uførhet og psykisk sykdom. Arbeid og velferd, 1, 37-49. Hentet fra https://www.nav.no/no/NAV+og+samfunn/Kunnskap/ Analyser+fra+NAV/Arbeid+og+velferd/Arbeid+og+velferd/ung-uf\%C3\%B8rhetog-psykisk-sykdom

Bragstad, T. (2018). Vekst i uføretrygding blant unge. Arbeid og Velferd, 2, 69-87. Hentet fra https://www.nav.no/no/NAV+og+samfunn/Kunnskap/ 
Analyser+fra+NAV/Arbeid+og+velferd/Arbeid+og+velferd/vekst-iuf\% $\mathrm{C}_{3} \%$ B 8 retrygding-blant-unge

Christensen, K. (2009). In(ter)dependent lives. Scandinavian Journal of Disability Research, 11(2), 117-130. http://doi.org/10.1080/15017410902830553

Dahl, E. \& Lorentzen, T. (2003). Explaining exit to work among social assistance recipients in Norway: heterogeneity or dependency? European Sociological Review, 19(5), 519-536. https://doi.org/10.1093/esr/19.5.519

Dencker-Larsen, S. \& Lundberg, K.G. (2016). Depicted welfare recipient stereotypes in Norway and Denmark: a photo elicitation study. Nordic Journal of Social Research, 7, 1-15. https://doi.org/10.7577/njsr.2098

Durkheim, E. (1995). The Elementary Forms of Religious Life. New York: The Free Press.

Dølvik, J.E., Fløtten, T., Hippe, J.M., \& Jordfald, B. (2014). The Nordic Model Towards 2030: A New Chapter? (NordMod 2030 Final Report. FAFO Rapport 7/14). Oslo: Fafo.

Elder, G.H., Kirkpatrick Johnson, M. \& Crosnoe, R. (2003). The emergence and development of life course theory. I J.T. Mortimer \& M.J. Shanahan (Red.), Handbook of the Life Course (s. 3-19). New York: Kluwer Academic.

Elias, N. (1970). What is Sociology? New York: Columbia University Press.

Esping-Andersen, G. (2009). The Incomplete Revolution: Adapting to Women's New Roles. Cambridge: Polity.

Fahnøe, S. (2017, 12. februar). Husker du Dovne Robert? Nu har hans arbejdsliv taget en overraskende drejning. Berlingske Tidende. Hentet fra https://www. bt.dk/danmark/husker-du-dovne-robert-nu-har-hans-arbejdsliv-taget-enoverraskende-drejning

Folbre, N. \& Wolf, D. (2013). The intergenerational welfare state. Population and development review, 38(1), 36-51. https://doi.org/10.1111/j.1728-4457.2013.00550.x

Frank, R.H. (2016). Success and Luck: Good Fortune and the Myth of Meritocracy. Princeton: Princeton University Press.

Frank, T. (2016). Listen, Liberal: Or What Ever Happened to the Party of the People. Victoria: Scribe.

Fraser, N. \& Gordon, L. (1994). Dependency demystified: inscriptions of power in a keyword of the welfare state. Social Politics, 1(1), 4-31. https://doi.org/10.1093/sp/1.1.4

Gerhardsen, R. (1991). Snillisme på norsk. Oslo: Schibsted.

Giddens, A. (1998). The Third Way: The Renewal of Social Democracy. Cambridge: Polity.

Gullestad, M. (1996). From Obedience to Negotiation: Dilemmas in the Transmission of Values Between the Generations in Norway. The Journal of the Royal Anthropological Institute, 2(1), 25-42. https://doi.org/10.2307/3034631 DOI: $10.2307 / 3034631$ 
Hagestad, G. (2009). Interdependent lives and relationships in changing times: a life-course view of families and aging. I W. Heinz, J. Huinink \& A. Weymann (Red.), The Life Course Reader (s. 397-415). Frankfurt: Campus.

Hansen, H.-T. (1996). Trygd - en midlertidig bro, eller en vei ut av arbeidsmarkedet? (dr.philos.-oppgave). Sosiologisk institutt, Universitetet i Bergen.

Hansen, H.-T. (2008). The dynamics of social assistance recipiency: Empirical evidence from Norway. European Sociological Review, 25(2), 215-231. https://doi. org/10.1093/esr/jcno40

Hansen, K.V. (2004). Not-So-Nuclear Families: Class, Gender, and Networks of Care. New Brunswick: Rutgers University Press.

Hills, J. (2015). Good Times, Bad Times: The Welfare Myth of Them and Us. Bristol: Policy Press.

Johansson, S. (1977). Om «Att Ha, att Älska, att Vara»: En kritisk granskning av en jämförande undersökning av välfärd i Norden. Sociologisk Forskning, 14(4), 37-58. Hentet fra http://www.jstor.org/stable/20851765

Jones, O. (2014). The Establishment: And How They Get Away With It. London: Allen Lane.

Kann, I.C. \& Sutterud, L. (2017). Utenforskap og trygdeordningenes rolle: sikkerhetsnett eller hvilepute. Arbeid og Velferd, (3), 59-79. Hentet fra https:/www.nav.no/no/NAV+og+samfunn/Kunnskap/Analyser+fra+NAV/ Arbeid+og+velferd/Arbeid+og+velferd/utenforskap-og-trygdeordningenes-rolle

Kohli, M. (2015). Cleavages in aging societies: generation, age or class?. I B. Marin (Red.), The Future of Welfare in a Global Europe (s. 327-351). Farnham: Ashgate.

Kvist, J. (2015). A framework for social investment strategies: integrating generational, life course and gender perspectives in the EU social investment strategy. Comparative European Politics, 13(1), 131-149. https://doi.org/10.1057/ cep. 2014.45

Kvist, J., Fritzell, J., Hvinden, B. \& Kangas, O. (2011). Changing social inequality and the Nordic welfare model. I J. Kvist, J. Fritzell \& B. Hvinden (Red.), Changing Social Equality: The Nordic Welfare Model in the 21st Century (s. 1-22). Bristol: Policy Press.

Landsend, M. \& Monsen, Ø.N. (2015a, 28. mai). Jeg vil nave, synger Kjetil (18) i baksetet på rånekjerra. Dagbladet. Hentet fra https://www.dagbladet.no/video/ n5m7tAtEI5A

Landsend, M. \& Norum, Ø.N. (2015b, 29. september). «Jeg vil nave» sang Kjetil. Nå har han fått seg jobb. Slik gikk det med de unge «naverne». Dagbladet. Hentet fra https://www.dagbladet.no/nyheter/jeg-vil-nave-sang-kjetil-na-har-han-fatt-segjobb/60489413

Mannheim, K. (1936). Ideology and Utopia: An Introduction to the Sociology of Knowledge London: Routledge and Kegan Paul. 
Piketty, T. (2014). Capital in the Twenty-first Century. Cambridge, MA: Belknap Press.

Saraceno, C. (2002). Deconstructing the myth of welfare dependence. I C. Saraceno (Red.), Social Assistance Dynamics in Europe: National and Local Poverty Regimes (s. 235-259). Bristol: Policy Press.

Seip, A.-L. (1994). Veien til velferdsstaten. Norsk sosialpolitikk 1920-75. Oslo: Gyldendal Akademisk.

Sennett, R. \& Cobb, J. (1972). The Hidden Injuries of Class. New York: Vintage.

Stamsø, M.A. (2017). Organisering og finansiering av velferdstjenester. I M.A. Stamsø (Red.), Velferdsstaten i endring (s. 110-143). Oslo: Gyldendal.

Stiglitz, J.E. (2012). The Price of Inequality: How Today's Divided Society Endangers Our Future. New York: WW Norton \& Company.

Syltevik, L.J. (2006). Taking control of one's own life? Norwegian lone mothers experiencing the new employment strategy. Community, Work and Family, 9(1), 75-94. https://doi.org/10.1080/13668800500421036

Terum, L.I. \& Hatland, A. (2014). Sysselsetting og trygd under arbeidslinja. Søkelys på arbeidslivet, 31(1-2), 3-22. Hentet fra https://www.idunn.no/spa/2014/01-02/ sysselsetting_og_trygd_under_arbeidslinja_

Titmuss, R. (1958). The social division of welfare: some reflections on the search for equity. I R. Titmuss (Red.), Essays on 'The Welfare State' (s. 34-56). London: Unwin University Books.

Ulvund, F. (2002). «Byens Udskud»? Ein studie av karrierar som innsett $i$ tvangsarbeids- og straffanstaltar i Bergen ca. 1850-75. (dr.philos-avhandling). Historisk institutt, Universitetet i Bergen.

Vogt, K.C. (2016). The postindustrial society: from utopia to ideology. Work, Employment \& Society, 30(2), 366-376. https://doi.org/10.1177/0950017015577911

Wærness, K. (1978). The invisible welfare state: women's work at home. Acta Sociologica, 193-207. Hentet fra http://www.jstor.org/stable/24859739

Øyen, E. (1983). Velferd. I E. Øyen (Red.), Velferd og Ulikhet (s. 112-134). Oslo: Universitetsforlaget. 



\title{
ARTIKKEL 4
}

\section{Myten om eldrebølgen}

\author{
Karen Christensen, professor, Universitetet i Bergen, \\ Sosiologisk institutt
}

\section{Abstract}

Title: The myth of the "Elder Boom". Summary: The ageing population represents today one of the most central demographic challenges in many countries of the world, including Norway. In the public debate about the ageing population, the metaphor "Elder Boom" is increasingly being used. This article gives insight into the discussion in Norway and shows that the metaphor "Elder Boom" does not represent a constructive contribution to the ageing-population debate. The article provides arguments against two implications of the "Boom" metaphor: that ageing people are unwanted in society, and that older people represent a huge and increasing amount of welfare dependency. It shows how society over time has strived to control diseases (such as tuberculosis) in order to increase life expectancy. Society does, in fact, see old age as one of its major achievements, not as a problem as implied in the "Elder Boom" metaphor. The article also demonstrates how social policies implemented in the elderly-care sector in Norway have increasingly reduced services to elderly people while increasing allocation to younger people still of working age. By pointing out these changes in old age and elderly care over time, the article is a contribution to put an end to the myth of an "Elder Boom". Overall, it contributes to the understanding of how this myth, bolstered by the Western world's ideal of (welfare) independence, both stigmatizes and misconstrues elderly people's dependency on the welfare state, which is in fact decreasing for various reasons.

Keywords: Elder Boom, welfare metaphor, ageing population, old age, elderly care, welfare dependency

Sitering av denne artikkelen: Christensen, K. (2018). Myten om eldrebølgen. I K. Christensen \& L.J. Syltevik (Red.), Myter om velferd og velferdsstaten (s. 75-97). Oslo: Cappelen Damm Akademisk. https://doi.org/10.23865/noasp.47.ch4

Lisens: CC BY-NC 4.0 
De fleste ønsker å leve livet helt ut, nær sagt koste hva det koste vil. Man gir og tar gjennom livet, og noen gjør mer av det enn andre. Det burde være plass til alle, og en burde slippe å føle at det var på tide å gjøre det slutt for ikke å være til byrde (sitat fra Svein Olav Daatland: Klar for eldrebølgen? Dagbladet 27. februar 2000).

\section{Innledning}

'Eldrebølgen' er blitt en del av det norske vokabularet i det offentlige ordskiftet. Et google-søk presenterer på et halvt sekund 117 ooo resultater (24.01. 2018) og bringer en straks til Wikipedia, som uansett denne kildes tilfeldige karakter er en hyppig brukt informasjonskilde. Her fremstilles eldrebølgen som et begrep som primært henger sammen med den økte levealder og dernest som et (stort) problem: 'En slik økning i antallet alderspensjonister med behov for pensjon, behandling og pleie på sykehjem vil bli en økonomisk og praktisk utfordring for velferdsstaten Norge' (Eldrebølgen, 2018). Parallelt med dette domineres overskriftene om 'eldrebølgen', med noen fă unntak, av typer som disse: 'Eldrebølgen treffer i 2025'; 'Er Norge godt nok rustet for eldrebølgen?'; 'Slik rammer eldrebølgen norske kommuner'; 'Eldrebølgen blir et sjokk', 'Drukner vi når eldrebølgen kommer?'; og 'Hvem skal pleie oss når eldrebølgen slår inn?' Slike offentlige tekster tegner et skremmende og truende bilde av den demografiske utviklingen med en aldrende befolkning. Bølgemetaforen bidrar til at den aldrende befolkning og konsekvensene av denne aldringen fremstilles som en katastrofe som nærmer seg. Bølgemetaforen bidrar også til å fremstille den aldrende befolkning som uønsket og som en byrde for samfunnet (jf. sitatet fra Daatland, 2000). Selve bølge-'nedslaget' blir fremstilt som en trussel for samfunnet, den yngre befolkning (lønnsarbeiderne) og velferdsstaten, som på generøs måte skal yte pensjoner og pleie- og omsorgstjenester til det stigende antall eldre. Siden det ikke vites presis hvordan den 'rammer' og med hvilken styrke, fremstilles den dessuten som uforutsigelig i sin konkrete måte å ramme på.

Formålet med denne artikkelen er ikke å nedtone at det er knyttet utfordringer til den demografiske utviklingen med en aldrende befolkning. Dette utgjør en viktig både samfunns- og velferdspolitisk diskusjon i Norge så vel som i mange andre av verdens land, og sentrale bidrag til denne diskusjonen kommer fra empirisk baserte studier om eldre og 
eldreomsorg. Formålet her er å vise at bruken av eldrebølgemetaforen utgjør et lite konstruktivt bidrag til diskusjonen om utfordringene, fordi den styrker oppfatningen av at aldring først og fremst er et problem for samfunnet, og at de aldrende gruppers behov for hjelp fra velferdsstaten representerer en katastrofe for samfunnet. I det følgende vil jeg først gi innsikt i hvordan metaforen om 'eldrebølgen' oppsto, og hvilke innholdsmessige begreper som har styrket bølge-forståelsen. Dernest vil jeg bruke to argumentasjoner til å bidra til å nyansere diskusjonen om den aldrende befolkning. Formålet med å presentere disse argumentasjonene er å vise på hvilken måte eldrebølgen utgjør en myte. Den første argumentasjonen dreier seg om å vise at bølgens uønskede og uventede karakter ikke harmonerer med en historisk utvikling av levealderen, som tvert imot snarere handler om en tilstrebet normalisering av alderdommen. Den andre dreier seg om at bølgens 'skadevirkninger, særlig når det gjelder å ramme velferdsstatens pleie- og omsorgstjenester, fremstilles som å kreve et eksplosivt behov for tjenester til eldre. Men dette harmonerer lite med de reformer som er implementert i de kommunale helse- og omsorgstjenestene de seneste tiår, og spesielt for eldre.

I denne artikkelen vil jeg anvende gerontologiske teorier om aldring, norske statistiske data samt samfunnsvitenskapelig forskning til å underbygge diskusjonen. Begrepet 'eldre' vil primært defineres som personer over 67 år, fordi pensjonsalderen er den mest typiske måte, i forskning og statistikk, å definere avgrensningen av eldre på (men også $65+$ grensen brukes i statistikken fordi dette er dagens faktiske pensjonsalder). Ettersom pensjonsalderen i dag i deler av arbeidslivet kan utsettes til fylte 70/72 år, kan 'alderdomsgrensen' samtidig også sies å være i bevegelse.

\section{Bølgemetaforen - hvordan oppstår den, og hva handler den om?}

Bølgemetaforen kan sies å oppstå av to viktige grunner. Den ene handler om at selve metaforen føres inn i et offentlig ordskifte. Den andre handler om utviklingen av denne metaforen til å bli en betegnelse for et eldreproblem samfunnet har fått. 
I eldreomsorgslitteratur (se f.eks. Daatland \& Solem, 2011, s. 160) antas bølgemetaforen å ha en viktig opprinnelse i mellomkrigstidens diskusjoner om den tids endringer i befolkningsutviklingen henimot små fødselskull og flere eldre. Det var det svenske ekteparet Alva og Gunnar Myrdal, med bakgrunn i samfunnsøkonomi og et felles sosialdemokratisk engasjement, som i deres første svenske utgave av boken Kris i befolkningsfrågan i 1934 anvendte metaforen 'flodvåg'. Da det kom en oppfølgende dansk og norsk utgave (med bruk av materiale fra eget land) med samme tematikk, fulgte metaforen med. Man kan forstå flodbølgen som en forsterket utgave av bølgen, her anvendt med en satirisk undertone:

Som en følge av den endrede aldersfordeling vil vi derfor her i landet om noen årtier få en flodbølge av intellektuell senilitet i hele det sosiale liv, og den vil komme til å føles uutholdelig for den generasjon som til den tid står i sin kraftigste alder (Myrdal \& Myrdal, 1936, s. 125, norsk utgave).

Men i motsetning til hva dette sitatet uttrykker - nemlig en misbilligelse over aldring og et fokus på det aldrende samfunn som et problem - er ingen av disse fortolkningene riktige om det som var Myrdalparets hensikt med å diskutere befolkningsspørsmålet i mellomkrigstiden. Det var likevel disse fortolkningene som senere ble videreført. Myrdalparets hoveddiskusjon handlet ikke om eldrespørsmålet. Den handlet om det synkende fødselstallet i denne perioden. Deres politiske formål var å bidra til å endre det konservative ordskiftet i denne diskusjonen fra å handle om moralpredikener, forbud mot preventive midler og straffelovgivning (når det gjaldt abort), til å forstå befolkningsspørsmålet som sosialpolitisk. Med dette mente de å sette det synkende fødselstall i sammenheng med forhold som familiedannelsens nye betingelser under det moderne økonomiske og sosiale liv (som historisk har fulgt utviklingen etter industrialiseringen), arbeidsløshet og den forventede emansipasjonen for kvinner fra middelklassen som ville gjøre barnefødsler mer 'besværlige' (Myrdal \& Myrdal, 1936, s. 135). Men de var også opptatt av ansvaret generasjonene imellom slik det tydeliggjøres her om den generasjonen som Myrdal-paret selv hørte til:

I sin fruktbare alder økte den sin inntekt pr. konsumsjonsenhet ved ikke å reprodusere seg; den har derved øket sin levestandard og samtidig har den ved å 
spare penger, ved å livsforsikre sig og ved hjelp av lovgivningen, forskanset sig bak lovlige rettigheter til arbeidsfrie inntekter i sin alderdom, - men uten å sørge for at det kom tilstrekkelig mange unge efter dem, som kunde arbeide og produsere det som deres renteinntekter skulde betales med. Det blir ikke morsomt å leve og være gammel når den tid kommer, da vi som nu befinner oss i mellomaldrene, engang skal avlegge regnskap overfor våre barn (Myrdal \& Myrdal, 1936, s. 123).

Det interessante fra disse betraktningene i mellomkrigstiden er at 'flodbølgen' altså ikke handlet om at aldring er et problem. Den handlet om at ansvaret for den etterfølgende generasjon kunne ha vært større, selv om det også finnes en rekke reelle sosiale forklaringer på det synkende fødselstallet. Mens 'eldrebølge'-diskusjonen ville ha utviklet seg til en sosialpolitisk diskusjon om den hadde fulgt i sporet til Myrdal og Myrdal, fikk den en annen dreining, nemlig mot å forstå det aldrende samfunn som et problem.

For å belyse den dreiningen diskusjonen har tatt siden introduksjonen av flodbølgemetaforen, kan vi først se på hvordan 'eldreproblemet' mer konkret defineres i dag. I sin mest enkle form fremstilles problemet som den økende andel av befolkningen på 67 år og over. Under overskriften 'Eldrebølgen på vei' viser Statistisk sentralbyrå (2017, s. 3) for eksempel at eldrebølgen handler om en økning over tid fra 8 \% i 1950 til $15 \%$ i 2017 og fremskrevet til $18 \%$ i 2030. Omskrevet betyr det at nesten hver femte person omkring 2030 er minst 67 år gammel. Samtidig pekes det på at dette ikke kun har med økt levealder å gjøre. Det settes også i sammenheng med lave fødselstall (jf. også Myrdal-parets fokus), og det vises til at grunnen til at eldrebølgen 'ennå ikke helt har nådd oss', er at fruktbarhetstallet er relativt høyt (i europeisk målestokk) og innvandrerbefolkningen er ung. I de konkrete beregninger av økningen i andelen eldre opereres det med noe usikkerhet, og dette fremstilles gjennom beregninger som viser høye, lave og middels tall. Typisk brukes da middeltallene (se f.eks. Helse- og omsorgsdepartementet, 2013, s. 42), og det er også de som er brukt ovenfor.

Den demografiske utviklingen med en aldrende befolkning er blitt diskutert siden 1980-tallet, og nettopp fordi de statistiske beregningene i denne diskusjonen har en sentral, plass, er det av stor betydning hvordan de finner sted, og hvilke faguttrykk som brukes. På tross av at de enkelte beregninger primært handler om å forsøke å finne frem noen 
faktiske tall om den aldrende befolkningen, er det imidlertid et kjent fenomen at statistikk også kan være politisk, altså at den med sine faguttrykk og beregningsmåter også presenterer fenomener på bestemte måter. Et av de tidlige demografiske begrepene som ble brukt, er for eksempel forsørgelsesbyrden ('dependency ratio'). Denne kan finnes beskrevet som 'forholdet mellom den tærende og nærende del av befolkningen, dvs. den yrkespassive og yrkesaktive befolkning' målt etter alder for å være yrkesaktiv/-passiv (Brunborg, 1986, s. 15). For å ta hensyn til at for eksempel noen i yrkesaktiv alder ikke er yrkesaktive, kan man i stedet bruke begrepet forsørgelsesrate, og definere dette ut fra faktiske tall på forholdet mellom de som ikke kan livnære seg av egen inntekt fra arbeid, og de som er selvforsørgende (Brunborg, 1986, s. 15). På tross av at slike begrepsdiskusjoner i utgangspunktet er nøytrale (selv om dette vanskelig kan sies om uttrykkene 'tærende/nærende'), kan de imidlertid lett også bidra normativt til diskusjonen om det aldrende samfunn. Presiseringen som finner sted fra å bruke begrepet 'forsørgelsesbyrde' til i stedet å foreslå 'forsørgelsesrate', kan for eksempel ses som en tydeliggjøring av at problemet med den aldrende befolkning handler om en økt andel ikke-selvforsørgende personer (se Kornstad, 2017). I dag kalles forsørgelsesbyrden ofte 'omsorgsbyrde'. Den kan eksempelvis defineres som forholdet mellom de som er 65 og eldre (faktisk pensjonsalder og over), og de som er mellom 20 og 64 år (Rogne \& Syse, 2017), altså den befolkningsdelen med flest i lønnsarbeid. Med stigende tall fortolkes dette da som stigende 'omsorgsbyrde'. Selv om det også er knyttet omsorgsbyrde til barn og unge, som slik sett derfor også kunne inngå i dette regnestykket (se Brunborg, 1986) - et regnestykke som faktisk gir nedadgående tall helt til omkring 2010 (Holmøy, 2013) - er konsekvensen av å ta dem ut at det blir et mye tydeligere fokus på de gamle som en ny byrde for samfunnet (se også Odén, Svanborg \& Tornstam, 1993, for en innsiktsfull innføring i dette). Uten at det er snakk om misbruk av statistiske beregninger (se f.eks. Silverman, 2014, s. 9 for eksempler), kan bestemte beregningsmåter likevel bidra til å forstørre problemforståelsen. Medvirkende til dette kan også være at kvantitative data i form av statistiske beregninger har høy status i samfunnet (Silverman, 2014, s. 8-9). Spørsmålet blir da kun hvor stort problemet er, for eksempel i ulike regioner (Telle, 2017) og ulike kommuner (Kornstad, 2017). 
Mens innholdsbestemmelsen og de statistiske begreper og beregninger som gjøres, er viktige for retningen diskusjonen om den aldrende befolkning tar med eldrebølgemetaforen, kan det imidlertid ikke forklare den innebygde misbilligelsen. Den forklaringen kan sies å ha dype historiske røtter. Tilbake i antikkens filosofi kan vi finne en viktig tenkning om aldring og alderdom slik den var representert av Aristoteles (se Bakken, 2014; Beauvoir, 1972; Kirk, 1994). Ifølge Aristoteles handlet aldring og alderdom om en langsom, men tydelig degenerering av kroppen. Siden han så kropp og sjel som tett forbundet, innebar dette at han så på aldring og alderdom som en svekkelsesprosess frem mot døden. Med etableringen av den medisinske klinikk i Europa på 1800-tallet og mulighetene dette ga for å føre statistikk over endringer i den aldrende kroppen, ble svekkelsesteorien styrket av synet på alder som en medisinsk diagnose (Kirk, 1994). Selv om litteraturen peker på aldring og alderdom som en sosial konstruksjon med ulike fortolkninger i ulike samfunn og kulturer (se f.eks. Beauvoir, 1972), og det slik også har eksistert positive syn på alder, har svekkelsesforståelsen vært den dominerende over tid. Bakken (2018) utreder dette nærmere gjennom sin inngående analyse av mange sider ved det aldersparadoks som først ble uttrykt av Cicero: Vi vil alle leve lenge, men ingen vil være gammel. Det er denne urgamle og grunnleggende avstandtaken fra å bli gammel, altså den siste del av Ciceros påstand, som eldrebølgemetaforen får næring fra til sin misbilligelsesdel.

I det følgende skal jeg vise at økningen i antall eldre mennesker, som blir stadig eldre, i liten grad kan sies å være et uventet eller ikke tilstrebet fenomen i samfunnet.

\section{Bølgen kommer - men verken uventet eller uønsket}

I kontrast til den dramatiske karakter som bølgemetaforen innehar, som et fenomen som med stor og truende styrke 'skyller' innover samfunnet i dag, har økningen i levealder over tid vært sett på som et tegn på et samfunn med stigende velstand og folkehelse, og den har slik vært sterkt ønsket og tilstrebet. 
Ifølge befolkningsstatistikk har levealderen over tid økt med akselererende fart. Sammenliknet med 180o-tallet, da de første folketellingene fant sted, har den forventede levealder økt med omkring 35 år, jf. tabellen nedenfor, som også gir innsikt i viktige og vedvarende kjønnsforskjeller over tid.

\begin{tabular}{|l|c|c|c|c|c|c|c|}
\hline & $\mathbf{1 8 2 1 - 3 0}$ & $\mathbf{1 8 9 1 - 9 5}$ & $\mathbf{1 9 2 6 - 3 0}$ & $\mathbf{1 9 6 6 - 7 0}$ & $\mathbf{1 9 8 6 - 9 0}$ & $\mathbf{2 0 0 1 - 0 5}$ & $\mathbf{2 0 1 1 - 1 5}$ \\
\hline Menn & 45,0 & 49,1 & 61,7 & 71,1 & 73,1 & 76,9 & 79,7 \\
\hline Kvinner & 48,0 & 52,6 & 64,6 & 76,8 & 79,7 & 81,9 & 83,7 \\
\hline
\end{tabular}

Tabell 1: Forventet levealder for kvinner og menn over tid. ${ }^{1}$

Kilde: (Statistisk sentralbyrå (SSB), 2018a)

I 2017 er den forventede levealder ved fødsel 80,9 år for menn, og 84,3 år for kvinner. Det er en rekke grunner til disse demografiske endringene i forventet levealder. På den ene side handler de om en rekke initiativer og ordninger som forbedrer levestandard, boforhold og ernæring, bekjemper sykdommer m.m. og slik øker forventet levealder. På den andre side handler de også om en rekke forhold som virker stagnerende eller negativt inn på levealder, slik som epidemier, økonomiske kriser og kriger. Ettersom forventet levealder speiler befolkningens dødelighet (Folkehelseinstituttet, 2014), er typen av dødelighet betydningsfull for endringene. Den overordnede trenden handler om at mens dødsårsaken på 180o-tallet og en del av 1900-tallet var knyttet til infeksjonssykdommer, og særlig tuberkulose, er de dominerende dødsårsakene i dag knyttet til hjerte- og karsykdommer samt kreft (Pedersen, 2007), særlig for menn. Dette betyr også at dødsårsakene i dag snarere er knyttet til alderdom, mens de tidligere var knyttet til barndom, særlig spedbarnsalderen. Meget tidlige tall, tilbake til før 1800-tallet, viser at 23 av 100 spedbarn døde; på slutten av 180o-tallet var dette falt til 10 av 100 (Fure, 2005). Deretter falt tallene sterkt igjennom tidene. I 2016 er det kun 2,2 barn av 1000 levendefødte som dør før ettårsalderen (SSB, 2018b). Bedre levestandard, ernæring og folkehelse, og etterkrigstidens utbygging av velferdsinstitusjoner og ordninger, inkludert etter hvert helsestasjonen med fødselsoppfølginger for mor og barn samt vaksinasjonsprogrammer, har vært viktige bidrag til denne reduksjonen over tid frem til i dag. Men enda viktigere for denne sammenhengen og for den generelle økte forventede levealder er det aktive 
og målrettede arbeid som ble gjort medisinsk for å bekjempe dødelige sykdommer. Dette gjaldt ikke minst bekjempelse av tuberkulosen, en dødelig infeksjonssykdom som fra 1900 til 1930-årene var den vanligste dødsårsaken for barn mellom 10 og 14 år og også den vanligste sykdomsårsak som førte til død helt frem til 1950 (Pedersen, 2007, s. 33). Mens bekjempelse av sykdommens sterke smittefare, særlig gjennom forbedring av hygiene, i starten bidro til å redusere tallene, var det avgjørende senere utviklingen av antibiotika som behandlingsmiddel for å overleve denne sykdommen.

Figur 1 viser utviklingen over tid for forventet levealder. Figuren gir et inntrykk av hvordan forventet levealder er et 'avtrykk' av sin samtid, og ikke bare påvirkes av levestandard og helse, men også av store samfunnskriser slik som ikke minst krig. Dessuten gir figuren et inntrykk av kjønnsforskjeller. Med økt levestandard fulgte også livsstilssykdommer som følge av særlig røyking, alkoholinntak og mindre næringsrike matvaner. Menn hadde sterkere tilbøyelighet til å utvikle livsstilssykdommer, og slik innvirket dette mer og litt tidligere på deres forventede levealder

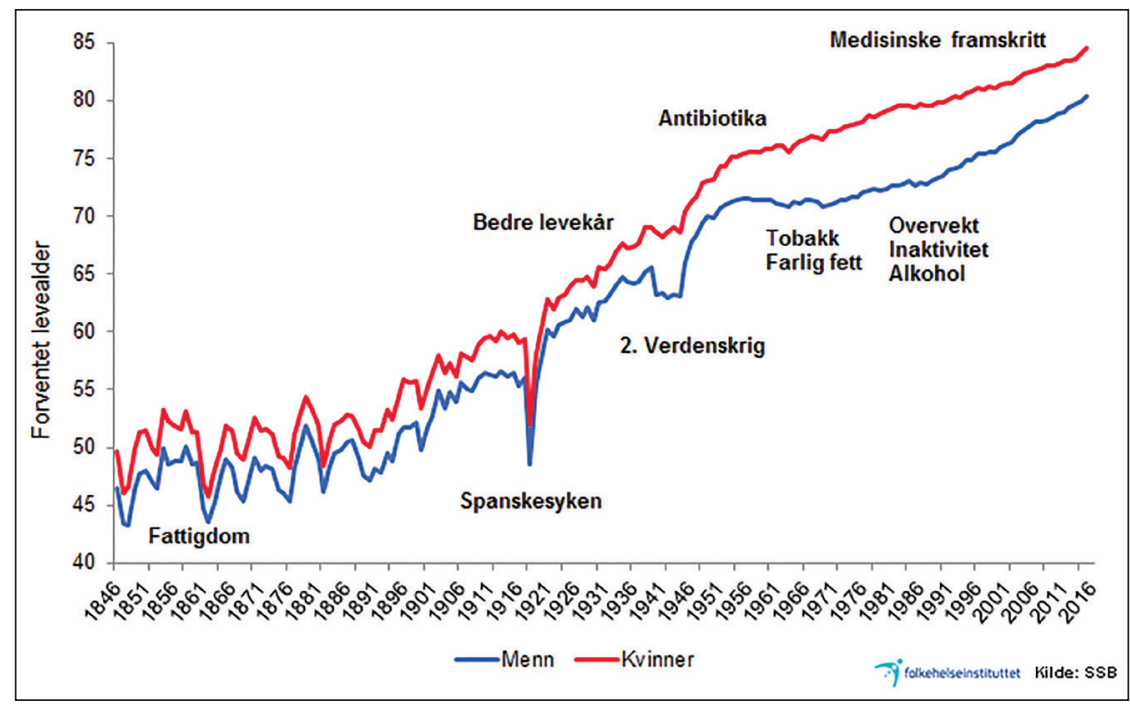

Figur 1. Forventet levealder i Norge, 1846-2013. Levealderen i Norge har økt dramatisk siden midten av 1800-tallet. Figuren viser at mens det tidligere var ujevne stigninger med periodevise nedganger i forventet levealder på grunn av fattigdom, krig, spanskesyke m.m. er økningen i forventet levealder i dag mye jevnere. Det finnes fortsatt klare forskjeller mellom kvinner og menns forventede levealder, men den er minskende. Mens den gjennomsnittlige forventede levealder i 1845 var litt under 50 år, er den i 2013 litt over 80 år. Kilde: Folkehelseinstituttet (2018). Folkehelserapporten: Levealderen i Norge, figur 1. Tilgjengelig fra: https://www.fhi.no/ nettpub/hin/befolkning/levealder/ Figuren er ikke omfattet av artikkelens lisens 
enn på kvinners. I dag går tendensen mot at forskjellene mellom menns og kvinners forventede levealder synker, fordi livet til menn og kvinner, gjennom kvinners økte deltakelse i arbeidsmarkedet og utdanning, er blitt mer likt (se f.eks. Christensen \& Syltevik, 2013), men fortsatt er det tre og et halvt års forskjell i forventet levealdersgjennomsnitt.

Det samlede bilde av utviklingen viser hvordan samfunnet aktivt har skapt betingelser for stadig høyere levealder. I 1960 hadde Norge verdens høyeste levealder (Folkehelseinstituttet, 2014). Men deretter er Norge blitt innhentet av en rekke land. Særlig har Japan en meget høy levealder, men det er også en rekke europeiske land som har innhentet Norge, og det pekes dessuten på økte sosiale forskjeller i landet. At det er et mål med en høy levealder, fremgår for eksempel av at dette er ett av de etablerte nasjonale mål i landets folkehelsemeldinger. Av den siste fremgår således at «Norge skal være blant de tre landene i verden som har høyest levealder» (Helse- og omsorgsdepartementet, 2015, s. 14). Det kan her nevnes at det blant de nasjonale målene også inngår et viktig mål om å redusere sosiale helseforskjeller. Dette anerkjennes slik som et problem knyttet til levealder i Norge. Denne stortingsmeldingen definerer 'tidlig død' som død før fylte 75 år (Helse- og omsorgsdepartementet, 2015, s. 15). Med andre ord understreker alt dette ønsket om etableringen av alderdom, altså høy levealder, som normalisert.

I samfunnsforskningen, og særlig i gerontologien, som er den vitenskap som har et spesifikt fokus på aldring og alderdom, er utviklingen møtt med nye teorier som bidrar til økt innsikt i alderdommens endringer. Innenfor det som kalles kronologisk alder (se f.eks. Daatland \& Solem, 2011, s. 23), har man tidligere inndelt livsløpet i tre deler: oppvekst, dernest arbeid (produksjon og reproduksjon) og så otium (hvile og pensjonstid). Daatland og Solem gjør oppmerksom på hvordan den kronologiske aldersinndelingen er et sosialt konstruert fenomen knyttet til moderne tid, med utvikling av tidsnormer for ulike roller. Slik skapes det bestemte normative forventninger til når ting skal skje i livet - uavhengig av subjektive oppfatninger - og i bestemte livsfaser knyttet til alder (Kohli, 2007), for eksempel pensjoneringstidspunktet. Når levetiden blir lengre, forskyves hele livsfasemønsteret (Odén, Svanberg \& Tornstam, 1993), og dette danner grunnlag for utviklingen av nye 
teorier. Den kronologiske alders tredje fase inndeles nå i to faser som kalles henholdsvis den 'tredje alder' og 'fjerde alder' (først av Laslett, 1996/1989). Det viktige fra disse teoriene om den tredje og fjerde alder er at det vises til et skille mellom den første og siste del av alderdommen. Typisk for den første delen er god helse og frihet fra lønnsarbeid (selv om denne friheten individuelt kan oppleves meget forskjellig; se Nordhus, Isaksen \& Wærness, 1986). Den siste delen handler så om det som i dag oppfattes som den 'egentlige' alderdom, nemlig den fasen som handler om en ny hjelpeavhengighet (jf. barndommen tidligere). Teoretisk betraktet handler normaliseringen av alderdom altså om at stadig flere eldre opplever den tredje alder i en stadig lengre periode, selv om det blant annet vil være viktige ulikheter knyttet til sosial klasse (jf. også Helse- og omsorgsdepartementet, 2015). Ulike generasjoner vil møte voksenfasen med ulike forutsetninger grunnlagt i barndommen og oppveksten. Slik har Elder (1974) for eksempel vist betydningen av depresjonstiden i 1930-årene for muligheten til å mestre eldre år senere, og i dag er fokuset på babyboomgenerasjonen. Dette er den store generasjon som ble født kort etter annen verdenskrig, vokst opp under velferdsstatens utbygning og som i dag møter alderdommen med flere ressurser (høyere utdanning og bedre økonomi) og andre forventninger enn tidligere generasjoner. Generasjonen beskrives i Stortingsmeldingen 'Morgendagens omsorg' som 'seniorgenerasjonen' (Helse- og omsorgsdepartementet, 2013, s. 55). Med dette er det en generasjonsforandring i gang som over tid handler om at de nye aldrende generasjoner vil stille større krav til samfunnet, og herunder velferdstjenester (Slagsvold \& Solem, 2005). Men dette handler i mindre grad om økende behov, og mer om innflytelse på det det er behov for; eller sagt på en annen måte: De eldre vil mer og mer ta livet i egne hender (Bakken, 2018). Dette forhindrer selvsagt ikke at det vil skje en kroppslig svekkelse med økt høy alder, og som for de fleste vil innebære en fase til sist, før døden, med hjelpeavhengighet. I det offentlige ordskifte skilles imidlertid ikke den første (uavhengighets-)fase fra den siste hjelpeavhengighetsfase, og slik bidrar dette til å fremstille hjelpeavhengigheten som en truende del av det aldrende samfunn (se også Vogts artikkel om fremstillingen av velferdsavhengighet mer generelt). 
I det følgende vil jeg se nærmere på det som metaforisk handler om at bølgen rammer samfunnet. Her vil jeg blant annet peke på at hjelpeavhengigheten i alderdommen, altså den fjerde alder, i måten den presenteres på, gir et sterkt overdrevet bilde av særlig alderdommens siste fase.

\section{Bølgen rammer - men forebygges økonomisk og møtes med minskende offentlig hjelp}

Det finnes tre implikasjoner i fremstillingen av bølgenedslaget som truende: Det vil bety store omkostninger, det vil utgjøre et kraftig nedslag, og det vil øke i styrke.

Selv om det ofte er økningen i helse- og omsorgstjenester som er i fokus når eldrebølgens omkostninger for samfunnet omtales, er også utgiftene til alderspensjoner en del av bildet. Da diskusjonen om den aldrende befolkning startet i begynnelsen av 1980-årene, førte det blant annet til igangsettelsen av viktige diskusjoner om endringer i pensjonssystemet, og betydelige endringer ble etter hvert satt i verk. Stoltenberg II-regjeringen implementerte således endringer på midten av 2000-årene som følge av et pensjonsforlik (se Stoltenberg, 2016), og bidro slik til å forebygge økonomiske utfordringer knyttet til en aldrende befolkning. På bakgrunn av disse forebyggende tiltakene har flere samfunnsvitenskapelige analyser kunnet tilbakevise oppfatningen av at økte utgifter til pensjoner vil bli en stor belastning i Norge. Andersen og Hatland (2014) har for eksempel dokumentert hvordan Norge, slik som de andre nordiske land, utviklet en rekke forebyggende pensjonsreformer, herunder også økte sin utnyttelse av arbeidskraften i den arbeidende del av befolkningen. Andersen og Hatland peker også på betydningen av relativt høye fruktbarhetstall, nettomigrasjonen til landet samt de nordiske lands generelle solide økonomiske utgangspunkt for å møte disse utfordringene. Konklusjonen er derfor at fremtidens pensjonsutgifter ikke vil true velferdsstaten (Andersen \& Hatland, 2014, s. 281).

Når det gjelder implikasjonen om at det vil komme et omfattende og økende hjelpebehov blant eldre som skal dekkes, kan vi se på en 
samfunnsvitenskapelig unik longitudinell norsk studie som ble gjennomført av Romøren blant 434 eldre i Larvik, fra de var 80 år og frem til deres død (Romøren, 2003). Larvikstudien hadde som formål å få innsikt i funksjonsnedsettelser i eldre år, hvilket bidrag som ble gitt av uformelle omsorgsgivere (familie, venner m.m.) i de enkelte fasene av alderdommen, samt de eldres 'veier' gjennom ulike formelle velferdstjenester, herunder sykehusinnleggelser og opphold på eldreinstitusjoner (sykehjem m.m.). For denne sammenhengen kan studien gi innsikt i de siste faser av livet og betydningen av uformell og formell hjelp. Romøren fant viktige forskjeller mellom menn og kvinner (se Romøren, 2003, s. 163, figur 8.1 for en oversikt). Hos menn fant han at hjelpeavhengigheten først startet ved 82-årsalderen, hos kvinner ved 80-årsalderen (alle tall er gjennomsnittstall). Denne forskjellen henger sammen med at de yngre koner kan fungere som uformelle omsorgsytere for mennene i deres eldre år og slik minske de eldre menns hjelpeavhengighetstid. Hos både menn og kvinner fant han at hjelpeavhengigheten startet med en fase med hjemmetjenester (4,2 år for menn; 5,7 år for kvinner), mest hjemmehjelp og deretter en kort tid med hjemmesykepleie, dernest også en kort periode med diverse tilpasninger i hjemmet for å kunne bo lenger hjemme, meget korte perioder med sykehusopphold og endelig en siste kort periode med plass på et sykehjem. Dette er kanskje det mest overraskende funnet fra studien for diskusjonen her, nemlig at institusjonsfasen viste seg å være kort (1,9 år for menn, 3,8 år for kvinner). Det hører med til dette bildet at familieomsorgen var et bidrag i alle fasene og til sammen varte i 5,3 år for kvinner og 8,8 år for kvinner. Ettersom institusjonstjenester er betydelig mer kostnadskrevende enn hjemmetjenester - fordi hjemmetjenestene er en type kortvarige punkttjenester i hjemmene, avgrenset og forhåndsdefinert - er det slik en viktig innsikt Larvikstudien har gitt med hensyn til funnet av en relativt kort og komprimert fase med institusjonsopphold (det som kalles langtidsopphold) på slutten av livet. En nyere studie, basert på statistiske (IPLOS) data, viser at Larvikstudiens gjennomsnittlige tall for total institusjonsliggetid på 3,2 år var sunket til 2 år. Mer presis uttrykt fant Gabrielsen at beboere som døde på sykehjem, i gjennomsnitt hadde hatt et langtidsopphold på institusjonen i 2 år (Gabrielsen, 2013). 
Larvikstudiens deltakere hadde opplevd sitt voksne liv mellom to verdenskriger, i en økonomisk nedgangstid. En del av dem forble også barnløse, mens mange av dem med barn hadde disse boende hos seg (grunnet boligmangel) helt til de døde. (Romøren, 2003, s. 6). Slik har denne eldre-kohorten møtt alderdommen med andre erfaringer enn det som gjelder den mer ressurssterke babyboomgenerasjonen som vokste opp i en oppgangstid og i dag er i deres tredje alder og sjeldnere bor sammen med deres barn. Velferdstjenestene har samtidig endret seg over tid. Fokuset på hjemmetjenester er siden Larvikstudien blitt enda sterkere, og i stigende grad brukes også teknologi, samt rehabiliteringstiltak, for å begrense bruken av offentlige tjenester til et minimum, jf. den såkalte omsorgstrappa, som brukes i norske kommuner (Helsedirektoratet, 2016, s. 39-48). Omsorgstrappa handler om å sikre at alle muligheter er utnyttet før det settes inn nye tiltak på et høyere ressursnivå, det vil si at det til enhver tid er det laveste effektive omsorgsnivå som skal brukes (se også Øydgard, 2018). Et viktig moment her, som også bidrar til den generelle minimering og utsettelse av behov for offentlig hjelp, handler om det internasjonalt inspirerte fokuset på 'aktiv aldring'. Dette dreier seg om en politikk som skal legge vekt på forebyggende og intervenerende tiltak, herunder konkrete tiltak som hverdagsrehabilitering, der et tverrfaglig team utvikler en plan for å opprettholde funksjonsevnen (se Hansen \& Kamp, 2016; Ness et al., 2012) samt støttekontakt og dagaktivitetstilbud (Helsedirektoratet, 2016). Det generelle målet med slike tiltak er å sikre en så lang som mulig sunn og aktiv alderdom (se Helse- og omsorgsdepartementet, 2013). For diskusjonen her beskriver dette en utvikling som i liten grad kan sies å handle om et kraftig bølgenedslag. I det følgende skal jeg vise at også implikasjonen om styrken, eller økningen over tid av eldres bruk av helse- og omsorgstjenester, ikke stemmer.

I motsetning til hva mange tror, er helse- og omsorgstjenester ikke forbeholdt eldre. Disse tjenestene er i dag forankret i den felles loven for helsetjenester og sosiale tjenester, helse- og omsorgstjenesteloven (lov om kommunale helse- og omsorgstjenester m.m. fra 2011, med ikrafttreden 1. januar 2012). Loven forplikter norske kommuner til å ha ansvar for å tilby en rekke tjenester. Disse omfatter institusjonstjenester (sykehjem, aldershjem, omsorgsboliger) og hjemmetjenester (praktisk hjelp, hjemmesykepleie) samt også såkalt nye omsorgstjenester, som trygghetsalarm 


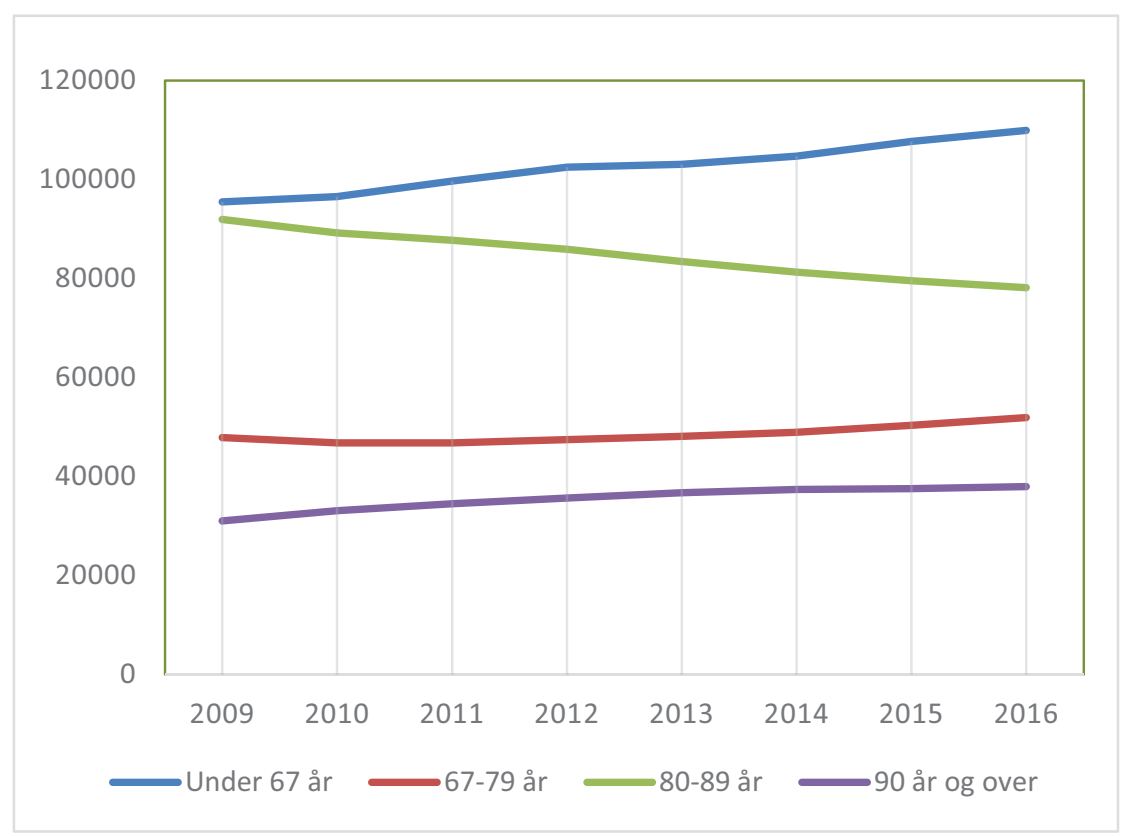

Figur 2. Antall mottakere av helse- og omsorgstjenester 2009-2016 etter alder. ${ }^{3}$ Antall mottakere av helse- og omsorgstjenester varierer etter alder. Figuren viser perioden fra 2009 til 2016. I dette tidsrommet er det aldersgruppen under 67 år som klart har den største økningen. I tall øker denne aldersgruppen fra omkring 95500 til omkring 110000 personer. De mellom 67 og 79 år samt de mellom 80 og 89 år øker kun lite i antall i perioden, men med den yngste av disse gruppene på et høyere nivå. For aldersgruppen mellom 80 og 89 år derimot er det en klar nedgang, fra 92000 til 78 000. Kilde: Statistisk sentralbyrå (SSB), 2018c.

og matutbringing. Mens eldre over 67 år (tidligere 65 år) hele tiden har vært og fortsatt utgjør den dominerende mottakergruppe, er det samtidig skjedd en viktig endring over tid, som illustrert ved figur 2.

Figur 2 viser en utvikling som er registrert statistisk siden begynnelsen av 1990-tallet (se f.eks. NOU 2011:11), og denne handler om at en økende andel av tjenestene går til personer under 67 år. Det er også unge eldre brukere (67-79 år) som ligger høyere i antall enn de over 90 år, og gruppen har også en liten økning. Siden de vil befinne seg i en tidlig hjelpeavhengighetsfase, vil mange av dem være brukere av hjemmetjenester og ikke institusjonstjenester (jf. tidligere). Helhetsbildet av en nedgang i tjenester for eldre er slik klart. Figur 3, som viser endringene i antall mottakere av hjemmetjenester, bekrefter også dette bildet. Mens det er en klar økning i antall brukere av hjemmetjenester under 67 år, er det kun 


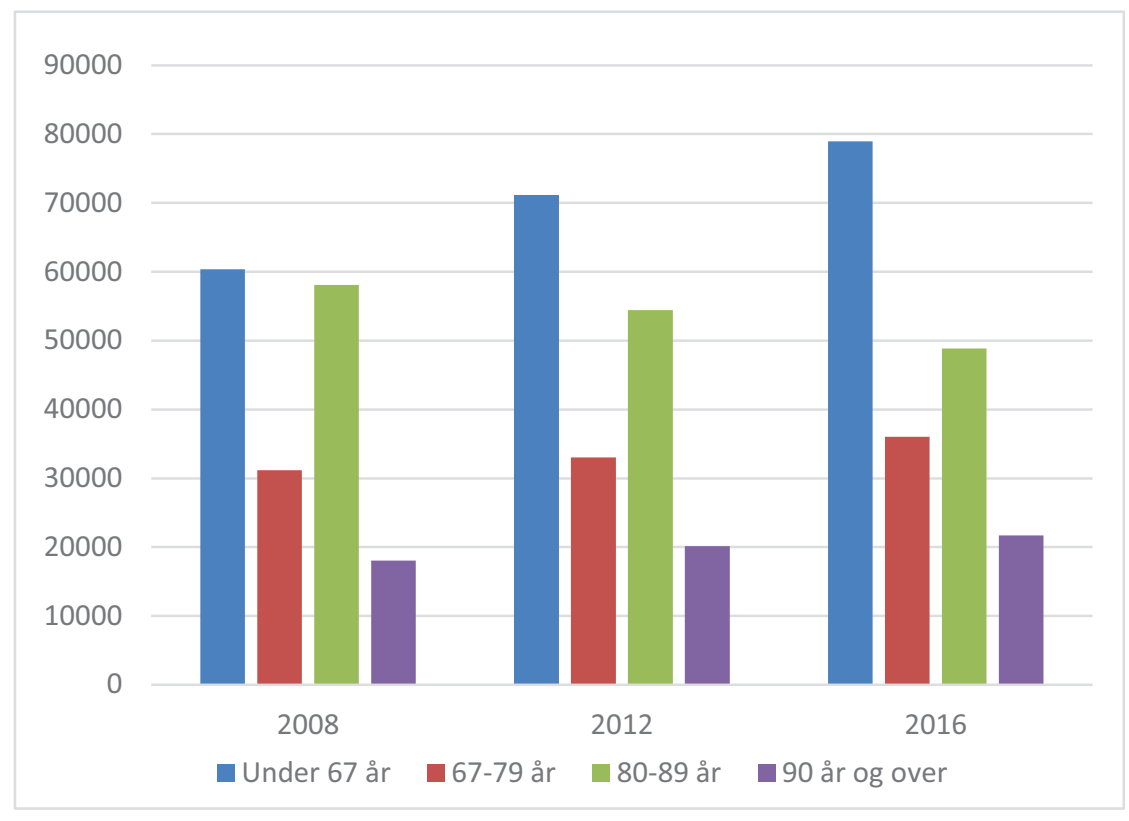

Figur 3. Antall mottakere av hjemmetjenester i årene 2008, 2012 og 2016 etter alder. ${ }^{4}$ Antall mottakere av hjemmetjenester varierer etter alder. Figuren viser antall mottakere i årene 2008, 2012 og 2016. Mens aldersgruppen under 67 år har den klareste økningen i disse årene, finnes det en mindre økning for aldersgruppen 67 til 79 år, og en enda mindre økning for aldersgruppen over 90 år. Figuren viser, at det er aldersgruppen 80 til 89 år som reduseres. De reduseres fra 58 000 i 2008 til 49000 personer i 2016. Kilde: Statistisk sentralbyrå (SSB), 2018c.

en liten økning i aldersgruppen 67-79 år. For de eldste aldersgruppene kunne man ha forventet en større økning, også selv om en del i denne aldersgruppen må antas å gå over til å bli institusjonsbrukere. For alle eldre under ett er bildet relativt entydig: Det er skjedd en nedgang i tildelingen av hjemmetjenester, og denne nedgangen er en trend som går flere tiår tilbake i tid (se Borgan, 2012, s. 36).

Samfunnsforskningen har karakterisert denne utviklingen som en endring i retning av økende 'yngreomsorg' (Romøren, 2007; se også Brevik, 2010) innen kommunale helse- og omsorgstjenester, som ellers over lang tid har vært kalt for eldreomsorgstjenester. Flere forhold kan sies å bidra til å styrke denne endringen mot yngreomsorg. For det første antas det at en $ø$ kende andel av de (ressurssterke) eldre i fremtiden vil komme til å kjøpe flere private tjenester. Slik vil de selv bidra til å minske trykket på de offentlige tjenester, og kanskje vil de også føle seg mer presset til dette når terskelen for å få hjelp stadig heves, jf. kommunenes bruk av 'omsorgstrappa' 
(nevnt ovenfor). For det andre kan det nevnes at forskning har vist at vurderingen av hjelpebehov hos yngre og eldre ikke følger den samme modellen. Betydningen av vurderingen av hjelpebehovet er kommet sterkere $\mathrm{i}$ fokus i sektoren etter at mange kommuner utover på 1990-tallet begynte å innføre den New Public Management-inspirerte bestiller-utfører-modellen (se f.eks. Christensen, 2012; Vabø, 2012). Den innebærer at bestillingen av tjenestene, basert på en vurdering av hjelpebehovet, er adskilt fra tjenesteutøvingen. Mange kommuner har i forlengelsen av dette innført et eget bestillerkontor, og med det en utvikling mot å profesjonalisere 'bestillingen', herunder nye måter å vurdere behov på. Hamran og Moe (2012) har for eksempel funnet at mens yngre i vurderingen av deres hjelpebehov ble sammenlignet med funksjonsfriske unge mennesker på samme alder, ble ikke eldres hjelpebehov sett i forhold til eldre på samme alder uten hjelpebehov. For denne sammenhengen kan man si at dette bidrar til mer innsikt i hvordan begrensningen av tjenester iverksettes. Igjen stiller de eldre svakest, siden Hamran og Moes studie peker i retning av at yngres hjelpebehov potensielt oppfattes som mer seriøse. Det kan være en medvirkende forklaring på dette at de yngre oppfattes som medlemmer av den 'aktive' befolkningsdelen, ikke den 'passive' (tærende), som de eldre.

\section{Avsluttende diskusjon}

I diskusjoner om velferd har begrepet om uavhengighet oppnådd en høy status gjennom tidene (Fraser \& Gordon, 1994), og det regnes som et av de mest sentrale generelle begreper i det 2o. århundret (se også artiklene til Syltevik og Vogt). Den individuelle uavhengighet er gjort til et ideal i den vestlige verden, og man kan her kalle dette for en historisk kontekst som har gitt medvind til diskusjonen om en eldrebølge. Uavhengighetsidealet betyr at avhengighet av andre fratas sin naturlige sosiale form, og i stedet stigmatiseres. Avhengighet gjøres til en skam for den enkelte; du kan gjerne leve lenge, men du må være innstilt på å ta et større individuelt ansvar (se Christensen \& Fluge, 2016, som viser hvordan den politiske norske eldreomsorgsretorikk i stigende grad handler om individuelt ansvar). I det offentlige ordskifte bidrar dette uavhengighetsidealet til å forstørre avhengigheten til eldre mennesker, og jo mer dette adskilles fra 
endringer over tid i aldring og alderdom, samt i eldreomsorgen, jo mer problematisk kan det aldrende samfunn fremstilles.

Denne artikkelen har vist at eldrebølgen er en myte i den forstand at den ikke harmonerer med to sentrale utviklinger i samfunnet og eldreomsorgssektoren. Den første er at lengre levetid har vært et ønsket og tilstrebet mål i det norske samfunn i flere hundre år og er blitt betraktet som et suksessmål for forbedrede levestandarder og kontroll med sykdommer gjennom tidene. Diskusjonen om den aldrende befolkning som føres ved hjelp av eldrebølgemetaforen, har vridd dette positive til noe negativt. Og med (uintendert) hjelp fra avanserte statistiske mål som 'forsørgelsesbyrde'/omsorgsbyrde' er byrdesiden av diskusjonen blitt intellektualisert. Det regnes da også for å være mest akademisk kraft i den pessimistiske fremstillingen (Pinker, 2018, s. 48). Den andre utviklingen handler om at eldreomsorgssektoren de siste tiår har implementert en politikk som innebærer at eldres andel av de kommunale helse- og omsorgstjenester, sett i et helhetsbilde, er redusert. Den antas dessuten å reduseres ytterligere på grunn av nye forventninger til de kommende (ressurssterke) seniorgenerasjoner. Dertil kommer at eldre, i sammenligning med yngre aldersgrupper, taper i 'konkurransen' fordi eldres status, sammenlignet med de yngres, jf. den klassiske diskusjonen om forholdet mellom de 'nærende' og 'tærende', er underordnet. Styrken i slike dreininger henter kraft fra sine dype historiske forbindelser til røtter i samfunnet, tilbake til antikkens filosofi om alderdom som en svekkelsesprosess, i dag fortolket som økende avhengighet av velferdsstaten.

I den offentlige utredningen om innovasjon i omsorgstjenestesektoren diskuteres en rekke myter om omsorgstjenestene, blant annet myten om eldrebølgen (NOU 2011:11, 2011, s. 25-26). Det pekes på at det er snakk om en myte av følgende grunner: Den store veksten i antall eldre på 80 år og eldre kommer først omkring 2025; sammenlignet med andre europeiske land er aldersendringene i Norge lite dramatiske; den nye seniorgenerasjonen er en generasjon med flere ressurser enn tidligere generasjoner og behovet for hjelp kan slik avta; og endelig at sammenhengen mellom levealder og behov for velferdstjenester er usikker på grunn av flere mulige scenarier: Flere leveår betyr flere gode leveår (altså ikke lengre perioder med funksjonsnedsettelse enn nå), flere leveår betyr bedre helse 
(perioden med funksjonstap blir kortere), og perioden med funksjonstap blir lengre (NOU 2011:11, 2011, s. 26). Det interessante for denne sammenhengen er ikke tilbakevisning av myten gjennom de relative tall som egentlig bare fremhever at problemet er litt mindre enn man antar, selv om det er positivt med tilbakevisning av myten nasjonalt og det styrker argumentene i denne artikkelen. Det interessante er at mytediskusjonen i denne utredningen ikke problematiserer det som kanskje kan sies å være selve kjernen i eldrebølgemetaforen, nemlig at den stigmatiserer eldre. Den stigmatiserer eldre som gruppe, peker ut deres økende hjelpebehov, og setter opp idealet - for alle eldre uansett alderdomsfase - om et lengre, sunnere og mer aktivt liv. Sett i et slikt lys er diskusjonen om seniorgenerasjonen ikke uttrykk for en ny respekt for hva seniorgenerasjonen kan bidra med i samfunnet etter lønnsarbeidet. Den gjøres primært til en ressursdiskusjon. Det handler om at seniorene på grunnlag av deres ressurser kan minske sin velferdsavhengighet og dermed de ressurser som det offentlige skal bruke, især på kommunale helse- og omsorgstjenester. Om de gjør det, vil de bidra til å minske fremtidens 'store' omsorgsbyrde.

Artikkelen er et bidrag til å øke kunnskapen om alderdom og eldreomsorg og til at færre får følelsen av at de må gjøre slutt på livet for ikke å bli oppfattet og fremstilt som en byrde for samfunnet, jf. innledningssitatet til Daatland (2000).

\section{Sluttnoter}

1. Tabellen er basert på tall fra Statistikkbanken (SSB, 2018a). Levealder. 05862 Forventet gjenstående levetid etter kjønn og utvalgte alderstrinn. Her er valgt o år som alderstrinn, dvs. ved tidspunktet for fødsel, og utvalgte intervaller (år).

2. I dette gjennomsnittstallet hos Gabrielsen (2013) er ikke medregnet beboere med et opphold på mer enn 10 år, fordi dette handler om noen få unntak og således ville vise frem et misvisende gjennomsnitt. IPLOS (individbasert pleie- og omsorgsstatistikk) er et pseudonymt dataregister som brukes av alle norske kommuner og inneholder informasjon primært om individers behov for bistand samt pleie- og omsorgstjenester de er tildelt.

3. Figur 2 er basert på tall fra Statistisk sentralbyrå (SSB, 2018c), Statistikkbanken, Brukere av helse- og omsorgstjenester, og dette omfatter brukere av bare praktisk hjelp, bare hjemmesykepleie, både praktisk hjelp og hjemmesykepleie, tidsavgrenset opphold i institusjon, langtidsopphold i institusjon og andre tjenester hjemme, målt de pågjeldende år på ett tidspunkt, 31/12. 
4. Figur 3 er basert på samme statistikk som figur 2 (SSB, 2018c), men avgrenset til brukere av hjemmetjenester: bare praktisk hjelp, bare hjemmesykepleie og både praktisk hjelp og hjemmesykepleie.

\section{Referanser}

Andersen, J.G. \& Hatland, A. (2014). Meeting the demographic challenges. Ageing and pension systems in the Nordic countries, in a European perspective. I P. Kettunen, S. Kuhnle \& Y. Ren (Red.), Reshaping welfare institutions in China and the Nordic countries (s. 257-288). Helsinki: Nordic Centre of Excellence NordWel. Hentet 19. oktober 2018 fra http://hdl.handle.net/10138/45403

Bakken, R. (2014). Frykten for alderdommen. Om å eldes og leve som gammel. Oslo: Res Publica.

Bakken, R. (2018). Alle vil leve lenge: men ingen vil bli gamle. Bergen: Fagbokforlaget. Beauvoir, S. de (1972). The coming of age. New York: G.P. Putnam's Sons.

Borgan, J.-K. (2012). Pleie- og omsorgsstatistikk 1962-2010 (Statistisk sentralbyrå (SSB) Rapport 10/12). Hentet 19. oktober 2018 fra https://www.ssb.no/a/ publikasjoner/pdf/rapp_201210/rapp_201210.pdf

Brevik, I. (2010). De nye hjemmetjenestene - langt mer enn eldreomsorg. Utvikling og status i yngres bruk av hjemmebaserte tjenester 1989-2007 (Norsk institutt for by- og regionforskning NIBR Rapport 2/10). Hentet 19. oktober 2018 fra www.hioa.no/Om.../NIBR/.../De-nye-hjemmetjenestene-langt-mer-enneldreomsorg

Brunborg, H. (1986). Demografiske ord og begreper. Serie: Interne notater 86/31. Hentet 19. oktober 2018 fra https://www.nb.no/items/URN:NBN:no-nb_ digibok_2011102508082

Christensen, K. (2012). Aldring sett i et sosiologisk perspektiv. I M. Bondevik, \& H.A. Nygaard (Red.), Tverrfaglig geriatri. En innføring (3. utg.) (s. 33-49). Bergen: Fagbokforlaget.

Christensen, K. \& Syltevik, L.J. (2013). Lønnsarbeid og kvinnearbeid - tilbake til diskusjonen om arbeid. Tidsskrift for kjønnsforskning, 37(2), 157-170. Hentet 19. oktober 2018 fra https://www.idunn.no/tfk/2013/o2/loennsarbeid_og_ kvinnearbeid_tilbake_til_diskusjonen_om_ar

Christensen, K. \& Fluge, S. (2016). Brukermedvirkning i norsk eldreomsorgspolitikk - om utviklingen av retorikken om individuelt ansvar. Tidsskrift for velferdsforskning, 19(3), 261-277. https://doi.org/10.18261/issn. 2464-3076-2016-03-04

Daatland, S.O. (2000, 27. februar). Klar for eldrebølgen? Dagbladet. Hentet 19. oktober 2018 fra https://www.dagbladet.no/nyheter/klar-foreldrebolgen/65580817 
Daatland, S.O. \& Solem, P.E. (2011). Aldring og samfunn (2. utg.). Bergen: Fagbokforlaget.

Elder, G. (1974). Children of the Great Depression: Social Change in Life Experience. Chicago: The University of Chicago Press.

Folkehelseinstituttet (2014). Folkehelserapporten 2014. Kapittel: Levealder i Norge. Hentet 7. februar 2017 fra https://www.fhi.no/nettpub/hin/

Fraser, N. \& Gordon, L. (1994). 'Dependency' demystified: inscriptions of power in a keyword of the welfare state. Social Politics, 1(1), 4-31. https://doi.org/10.1093/ $\mathrm{sp} / 1.1 .4$

Fure, E. (2005). Spedbarnsdødeligheten i Asker og Bærum på 1700- og 180o-tallet. Tidsskrift for Den norske loegeforening, 125, 3468-3471. Hentet 19. oktober 2018 fra https://tidsskriftet.no/2005/12/medisinsk-historie/ spedbarnsdodeligheten-i-asker-og-baerum-pa-170o-og-180o-tallet

Gabrielsen, B. (2013). Færre eldre bor på sykehjem. I J. Ramm (Red.) Eldres bruk av helse- og omsorgstjenester. Statistisk Sentralbyrå (SSB) Statistiske analyser (s. 93-100). Hentet 19. oktober 2018 fra https://www.ssb.no/helse/artikler-ogpublikasjoner/eldres-bruk-av-helse-og-omsorgstjenester

Hamran, T. \& Moe, S. (2012). Yngre og eldre brukere i hjemmetjenesten - ulike behov eller forskjellsbehandling. Flerfaglig praksis $i$ et interaksjonistisk perspektiv (Senter for omsorgsforskning Nord Rapport nr. 3/12). Tromsø: Senter for omsorgsforskning Nord.

Hansen, A. \& Kamp, A. (2016). From carers to trainers: professional identity and body work in rehabilitative eldercare. Gender, Work and Organizations, 25(1): 63-76. https://doi.org/10.1111/gwao.12126

Helse- og omsorgsdepartementet (2006). Mestring, muligheter og meninger. Framtidas omsorgsutfordringer (St.meld. nr. 25 (2005-2006)). Hentet 19. oktober 2018 fra https://www.regjeringen.no/no/dokumenter/stmeld-nr-25-2005-2006-/id200879/

Helse- og omsorgsdepartementet (2013). Folkehelsemeldingen. God helse-felles ansvar. (Meld. St. 34 (2012-2013)). Hentet 19. oktober 2018 fra https://www. regjeringen.no/no/dokumenter/meld-st-34-20122013/id723818/

Helse- og omsorgsdepartementet (2013). Morgendagens omsorg (Meld. St. 29 (2012-2013)). Hentet 19. oktober 2018 fra https://www.regjeringen.no/no/ dokumenter/meld-st-29-20122013/id723252/

Helse- og omsorgsdepartementet (2015). Folkehelsemeldingen. Mestring og muligheter (Meld. St.19 (2014-2015)). Hentet 19. oktober 2018 fra https://www.regjeringen. no/no/dokumenter/meld.-st.-19-2014-2015/id2402807/

Helsedirektoratet (2016). Helse-, omsorgs- og rehabiliteringsstatistikk. Eldres helse og bruk av kommunale helse- og omsorgstjenester (Rapport 02/16). Hentet 19. oktober 2018 fra https://helsedirektoratet.no/publikasjoner/helse-omsorgs-og-rehabiliteringsstatistikkeldres-helse-og-bruk-av-kommunale-helse-og-omsorgstjenester 
Holmøy, E. (2013). Har den norske velferdsstaten et finansieringsproblem på lang sikt? Innledning på KRD (Kommunal- og regionaldepartementet) seminar Lysebu 12.03.2013. Hentet 19. oktober 2018 fra http://www.uio.no/om/samarbeid/ samfunn-og-naringsliv/partnerforum/arrangementer/partnerseminar/2013/ holmoy_120313.pdf

Kirk, H. (1994). Da alderen blev en diagnose - konstruktionen av kategorien 'alderdom' i 180o-tallets logelitteratur. En medicinsk-idehistorisk analyse. København: Munksgaard.

Kohli, M. (2007). The institutionalisation of the life course: looking back to look ahead. Research in Human Development, 4(3), 253-271. https://doi. org/10.1080/15427600701663122

Kornstad, T. (2017). Utvikling i befolkningens forsørgelsesrater på kommunenivå som følge av en aldrende befolkning. Økonomiske analyser, 36(3), 34-40. Hentet 19. oktober 2018 fra https://www.ssb.no/inntekt-og-forbruk/artikler-ogpublikasjoner/utvikling-i-befolkningens-forsorgelsesrater-pa-kommunenivasom-folge-av-en-aldrende-befolkning

Laslett, P. (1996). A Fresh Map of Life: The Emergence of the Third Age (2. utg.). Basingstoke: Macmillan.

Myrdal, A. \& Myrdal, G. (1934). Kris i befolkningsfrågan. Stockholm: Albert Bonniers.

Myrdal, A. \& Myrdal, G. (1936). Krisen i befolkningsspørsmålet. (Norsk utgave ved A. Lionæs og A. Skaug). Oslo: Tiden Norsk Forlag.

Nordhus, I.H., Isaksen, L.W., \& Wærness, K. (1986). De fleste gamle er kvinner eldreomsorg fra et kvinneperspektiv. Bergen: Universitetsforlaget.

Ness, N.E., Laberg, T., Haneborg, M., Granbo, R., Færevaag, L., \& Butli, H. (2012). Hverdagsmestring og hverdagsrehabilitering. Oslo: Ergoterapeutene, Norsk Sykepleierforbund, Norsk Fysioterapeutforbund.

NOU 2011:11 (2011). Innovasjon i omsorg. Oslo: Statens forvaltningstjeneste.

Odén, B., Svanberg, A. \& Tornstam, L. (1993). Att åldras i Sverige. Stockholm: Natur \& Kultur.

Pedersen, A.G. (2003). 100 år med redusert spedbarnsdødelighet. Samfunnsspeilet, 17(3), 34-39. Hentet 19. oktober 2018 fra https://www.ssb.no/helse/artikler-ogpublikasjoner/10o-aar-med-redusert-spedbarnsdodelighet

Pedersen, A.G. (2007). Dødelighetsmønstret i endring: fra infeksjoner til livsstil. I R.R. Bore (Red.), Helsestatistikk i 150 år (s. 30-51). Historisk helsestatistikk. Hentet 19. oktober 2018 fra https://www.ssb.no/a/publikasjoner/pdf/sa94/del-ii-1b.pdf

Pinker, S. (2018). Enlightenment Now: The Case for Reason, Science, Humanism, and Progress. New York: Viking.

Rogne, A.F. \& Syse, A. (2017). Framtidens eldre i by og bygd.

Befolkningsframskrivinger, sosiodemografiske mønstre og helse (Statistisk 
sentralbyrå (SSB) Rapport nr. 32/17). Hentet 1. februar 2018 fra http://www.ssb.no/ befolkning/artikler-og-publikasjoner/framtidens-eldre-i-by-og-bygd?fane=om

Romøren, T.I. (2003). Last Years of Long Lives: The Larvik Study. London: Routledge.

Romøren, T.I. (2007). Kommunale hjemmetjenester - fra eldreomsorg til 'yngreomsorg'? Aldring og livsløp, 24(1), 1-11. Hentet 19. oktober 2018 fra www. hioa.no/content/download/44618/669176/file/2629_1.pdf

Silverman, D. (2014). Interpreting Qualitative Data. Los Angeles, London: Sage.

Slagsvold, B. \& Solem, P.E. (2005). Morgendagens eldre. En sammenligning av verdier, holdninger og atferd blant dagens middelaldrende og eldre (NOVA Rapport 11/05). Oslo: Norsk institutt for oppvekst, velferd og aldring.

Statistisk sentralbyrå (2017). Dette er Norge 2017. Tall som forteller. Hentet 1. februar 2018 fra https://www.ssb.no/befolkning/artikler-og-publikasjoner/dette-ernorge-2017

Statistisk sentralbyrå (2018a). 05862: Forventet gjenstående levetid, etter kjønn og utvalgte alderstrinn 1821-1830 til 2011-2015 [Datasett]. Hentet 1. februar 2018 fra https://www.ssb.no/statbank/table/05862

Statistisk sentralbyrå (2018b). 08373: Dødeligheten omkring fødselen og i første leveår [Datasett]. Hentet 1. februar 2018 fra https://www.ssb.no/statbank/table/o8373

Statistisk sentralbyrå. (2018c). o6969: Brukere av pleie- og omsorgstjenester. Alder og tjenester 2007-2016 [Datasett]. Hentet 31. januar fra https://www.ssb.no/statbank/ table/06969

Stoltenberg, J. (2016). Min historie. Oslo: Gyldendal.

Telle, K. (2017). Aldring og sysselsetting i by og bygd. (Statistisk sentralbyrå (SSB) Økonomiske analyser 4/17). Hentet 25. januar 2018 fra http://www.ssb.no/ nasjonalregnskap-og-konjunkturer/artikler-og-publikasjoner/aldring-ogsysselsetting-i-by-og-bygd-2017-04

Vabø, M. (2012). Norwegian home care in transition - heading for accountability, off-loading responsibilities. Health and Social Care, 2o(3), 283-291. https://doi. org/10.1111/j.1365-2524.2012.01058.x

Wikipedia (2018). Eldrebølgen. I Wikipedia. Hentet 24. januar 2018 fra https:// no.wikipedia.org/wiki/Eldreb\%C3\%B8lgen

Øydgard, G. (2018). Individuelle behovsvurderinger eller standardiserte tjenestetilbud? En institusjonell etnografi om kommunale saksbehandleres oversettelse fra behov til vedtak. Tidsskrift for omsorgsforskning, o1(4). Hentet fra https://www.idunn.no/tidsskrift_for_omsorgsforskning/2018/o1/individuelle_ behovsvurderinger_eller_standardiserte_tjenest 



\title{
ARTIKKEL 5
}

\section{Myten om alenemødrene og velferdsstaten}

\author{
Liv Johanne Syltevik, professor, Universitetet i Bergen, \\ Sosiologisk institutt
}

\section{Abstract}

Title: The Myth of Single Mothers and the Welfare State. Summary: In the last three decades, there have been two large public debates about single mothers and the welfare state in Norway; the first, initiated by the leader of the Progress Party during the electoral campaign in 1989, portrayed single mothers as parasites on the welfare state; the second, evident since the early 2000s, has focused on Somali single mothers and portrayed them as misusers of benefits for single parents. The article identifies significant myths in these public debates and discusses how they have changed. These stereotypes are compared with insights from research on the situation of single mothers, and the article demonstrates how the welfare benefits for the group have changed in the same period. The article ends with a discussion of the importance of myths in political debates. Myths may "work" both in direct and indirect ways. How influential they are, however, is always difficult to decide. The myths about single mothers have worked in the sense that they have set the agenda. This makes it important for researchers to take on the work of not taking myths as accepted truths, but to challenge and defy them.

Key words: Single mothers, public debates, welfare policy, stereotypes, myths

\section{Innledning}

Betydningen av sosiale ideer og forestillinger for utviklingen av offentlig politikk var lenge et oversett tema i samfunnsforskningen, men etter hvert har det vokst fram en relativt omfattende litteratur om forholdet

Sitering av denne artikkelen: Syltevik, L.J. (2018). Myten om alenemødrene og velferdsstaten. I K. Christensen \& L.J. Syltevik (Red.), Myter om velferd og velferdsstaten (s. 99-122). Oslo: Cappelen Damm Akademisk. https://doi.org/10.23865/noasp.47.ch5

Lisens: CC BY-NC 4.0 
mellom ideer og politikkutvikling (se bl.a. Bacchi, 1999; Beland \& Cox, 2010). Denne artikkelen vil ta for seg hvilke myter om enslige mødre som har vært fremtredende i offentlig debatt de siste tiårene, og diskutere hvordan de har påvirket offentlig politikk når det gjelder kategorien «enslige forsørgere». Hvilket ansvar velferdsstaten har i situasjoner der en foreldre har aleneansvar (helt eller delvis) for et barn, har hele tiden vært basert på oppfatninger om hvilke behov og utfordringer gruppen har $\mathrm{i}$ forhold til andre foreldre og barn, og hva som er og bør være velferdsstatens ansvar (Grødem, 2016; Syltevik, 1999). Konflikter mellom ulike ideer om problemer og løsninger inngår i debatter der også strukturelle samfunnsendringer har betydning. Når det gjelder gruppen enslige med barn, har gruppen enslige forsørgere endret seg i den aktuelle perioden på grunn av endringer i samlivsmønster, og det samme gjelder andre sider ved samfunnskonteksten rundt det å ha hovedansvaret for barn alene. For å nevne noe av det viktigste er mødres yrkesdeltakelse økt betydelig og likedan barnehagetilbudet.

Myter kan ses som konsentrerte uttrykk for viktige forestillinger og fortellinger i et samfunn, og er et utgangspunkt for å diskutere hvilken rolle stereotypier og misvisende forstillinger kan ha i utviklingen av velferdspolitikken. I artikkelen identifiseres to stereotypier i de store mediedebattene som har handlet om enslige mødre de siste 30 årene. Mens det på slutten av 1980-årene var snyltende alenemødre med trygd som var i fokus, er det i 2000-årene innvandrermødre og spesielt somaliske kvinner som har fått denne rollen. I artikkelen setter jeg disse stereotypiene opp mot hva forskning om gruppen enslige med barn har vist $\mathrm{i}$ samme tidsperiode, og presenterer hvilke endringer som har blitt gjort i stønadsordningene.

Artikkelen starter med en kort introduksjon til den norske trygdeordningen og hvordan gruppen enslig forsørger i lovverket har endret seg. Deretter er framstillingen kronologisk. Først presenteres debatten på slutten av 1980-tallet, forskningen om gruppen og politikkendringen som kom på 1990-tallet. Så presenteres mediedebatten etter 2000, forskningen om gruppen og politikkendringene som kom i kjølvannet av denne debatten. Artikkelen avsluttes med en sammenligning av mytene om enslige mødre i 1980- og 2000-årene, og en diskusjon av hvilken betydning 
disse forestillingene og stereotypiene kan ha hatt. Jeg argumenter for at dette har vært virksomme myter, i den forstand at de har vært med på å sette dagsorden for diskusjoner om hvilke endringer som trengs i politikken. Hvor stor betydning og hvilken rolle mytene har hatt, er imidlertid avhengig av styrken i andre ideer og i hvilken grad de har «passet» inn i andre utviklingstendenser.

\section{Stønadsordningene til enslige forsørgere og kategorien enslig forsørger}

Norsk politikk overfor enslige med barn har vært et av få eksempler internasjonalt på det Kamerman og Kahn (1988) kalte en kategorisk alenemor-strategi. Det å tilhøre kategorien enslig med barn har vært grunnlag for å motta støtte fra velferdsstaten. Ordningene har lange historiske røtter i Norge, tilbake til de Castbergske barnelovene i 1915. Vi fikk en trygdeordning for ugifte mødre i 1963, og en felles trygdeordning for alle kategorier enslige forsørgere fra 1981 (skilte, ugifte, kvinner og menn). På 1980-tallet var ordningen på sitt mest generøse, mens det etter den tid har skjedd en gradvis nedbygging av støtteordningene.

Hvordan kategorien har blitt forstått, har også endret seg i lovverket. Mens det i utgangspunktet var ekteskap som kvalifiserte eller diskvalifiserte for stønad, er det i dag mer komplisert. Samboerskap diskvalifiserer nå helt fra å betraktes som enslig forsørger, uansett om samboer er far/ mor til barnet/barna de bor med. Ordningene har også endret seg med hensyn til alder på barn og støtte til å være hjemme med barn. Mens grensen for å kunne være hjemme med barn tidlig på 1980-tallet var ca. 10 år, ble den 3 år på slutten av 1990-tallet og er i dag 1 år. Konteksten har også endret seg, fra at det var uvanlig med skilsmisse til at fraskilte i dag er den største gruppen av dem som har hovedansvar for barn alene. Fedres rolle i barneomsorg har også forandret seg, noe som blant annet betyr at det er blitt flere par som deler mer på ansvar også etter et samlivsbrudd. Det er dermed vanskeligere å skille mellom foreldrene med hensyn til hvem som har hovedomsorgen eller er samværsforelder. Fertilitetsteknologien har også ført til at flere kan velge å få barn uten en partner. I tillegg kommer 
også migrasjon inn og har bidratt til at gruppen har blitt mer heterogen enn tidligere. ${ }^{1}$

\section{Stormen om alenemødre - Carl I. Hagens utspill i 1989}

Før stortingsvalget i 1989 holdt Carl I. Hagen, Fremskrittspartiets daværende formann, en pressekonferanse på en valgturné i Finnmark. Her valgte han å ta for seg alenemødre. Han uttalte i korte trekk at alenemødre ved sin uansvarlige livsførsel hadde seg selv å takke for situasjonen, og mente at de fikk for mye offentlig hjelp. Dagen etter ble han intervjuet i Dagbladet, og oppslaget ble: «Jeg anklager: Latsabber, unnalurere, giddalause, uhøflige, respektløse, kravstore, uansvarlige og lettsindige kvinner» (Strandhagen, 1989, s. 8). Hagen hevdet at kvinner som fikk barn uten å ha et forhold til en mann, eller som skilte seg og lot være å ta lønnet arbeid, jukset til seg stønad fra velferdsstaten. Hagens utspill hadde en tydelig kjønnsdimensjon, han tegnet et bilde av kvinner som ved sin uansvarlige seksualitet og relasjon til menn snyltet på velferdsstaten. Dette utløste en mediestorm der de fleste av innleggene gikk imot Hagen. I stedet trakk mange fram innsatsen alenemødre gjorde ved å ta seg av sine barn, ansvaret som fraværende fedre ikke tok, og behovet disse familiene hadde for støtte fra fellesskapet (Syltevik, 1996).

Utspillet til Hagen kombinerte generelle oppfatninger om velferdsordninger (at de skaper avhengighet og passivitet) som vokste fram på denne tiden, med forestillinger om kjønn og kvinner som har lange historiske røtter. Allerede ved starten av det 19. århundret var det for eksempel i forbindelse med debatten om de Castbergske barnelovene en diskusjon om kvinner som utnyttet menn og gjorde dem til barnefedre med sikte på at deres barn deretter kunne arve dem (Syltevik, 2015). Sammenlignet med Hagens utspill er det interessant å merke seg at her var det mennene som ble utnyttet, mens det hos Hagen er velferdsstaten som blir det. Mehta (2010) skiller i en oversiktsartikkel om ideers funksjon i forhold til politikk mellom tre typer ideer: 1) ideer om politiske løsninger, 2) ideer om problemdefinisjoner og 3) mer overordnede ideer og filosofier (zeitgeist). Hagens utspill inneholdt alle disse elementene. Problemet ble forstått 
som å handle om kvinners uansvarlige atferd og umoral, og løsningene var mindre eller ingen støtte fra velferdsstaten. Den overordnede ideen var at velferdsavhengighet er et uunngåelig resultat av velferdsordninger og at den enkelte har ansvar for egen velferd.

Diskusjonen om alenemødrene som Hagens utspill innledet i Norge, var ikke et særnorsk fenomen, men kom i kjølvannet av debatter internasjonalt (jf. Hansens artikkel) særlig i USA og Storbritannia. I begge disse landene var enslige mødre i sentrum for debatter om velferdsytelser. I Storbritannia knyttet for eksempel The Secretary of State for Social Security John Moore i 1980 diskusjonen av det han kalte «avhengighetskulturen», til enslige mødre og refererte gjentatte ganger til en ung kvinne «in his constituency who allegedly wanted to become pregnant in order to get on the housing list» (referert i Skevik, 2001, s. 15; se også Vogts artikkel om velferdsavhengighet). Thatcher fulgte opp ved å si at de måtte ta affære på grunn av «The growing problem of the welfare state in the young girls who deliberately become pregnant in order to jump a housing queue and gain welfare payments» (referert i Skevik, 2001, s. 15). Også i USA fikk enslige mødre en viktig rolle i den offentlige diskusjonen om velferdsstøtte. Sarah McLanahan (1994) oppsummerte debatten i USA slik:

For example, conservatives as the former Education Secretary William Bennet and Charles Murray, the author of Losing Ground, believe that single motherhood is so harmful and public support is so significant an inducement for unwed women to have babies that it is time to get tough with the mothers. Murray has even proposed denying unwed mothers child support payments from nonresident fathers. In Murray's eyes, the mothers are fully responsible for any children they bear in an age when contraceptives and abortion are freely available. Of the father Murray says: As far as I can tell, he has approximately the same causal responsibility as a slice of chocolate cake has in determining whether a women gains weight (McLanahan, 1994).

I USA ble støtteordningen Aid for Families with dependent children (AFDC) avviklet etter denne debatten. AFDC var rettet mot fattige foreldre, men de fleste som hadde ordningen, var svarte mødre, og selve betegnelsen enslig mor ble i mange sammenhenger betraktet som 
synonym for «black, welfare mother» (Zucchino, 1997). Også i Storbritannia ble diskusjonen om støtte til enslige mødre knyttet til hudfarge og rase (Duncan \& Edwards, 1999).

Forholdet mellom barnefedrenes, kvinnenes og velferdsstatens ansvar har vært en spenning som har fulgt stønadsordningene. Hagen la vekt på at kvinnene selv hadde ansvar for sin situasjon ved å velge å få barn uten å kunne forsørge dem. Da Kari Wærness (1972) på starten av 1970-tallet skrev sin hovedfagsoppgave om skilte mødre som levde av sosialhjelp, tok hun opp hierarkiet blant enslige forsørgere med hensyn til offentlig hjelp. Mens enkene var verdig trengende fordi de uforskyldt var alene med sine barn, var det ikke like klart for de andre kategoriene. Når det gjaldt ugifte mødre, gikk velferdsstaten inn (riktignok under noe tvil og basert på at det var vedtatt en lov om abort, se presentasjon av diskusjonen i Stortinget i 1963 i Syltevik, 1996), og kompenserte for mangelen på en mann med forpliktelser. Når det gjaldt de skilte mødrene, var det nettopp ønsket om å ikke ta ansvaret fra mennene som bidro til at denne gruppen lenge ikke var omfattet av trygdeordningen, men hadde en egen ordning i tilknytning til sosialhjelpen.

\section{Hva var situasjonen til alenemødre i Norge ved inngangen til 1990-tallet?}

Det er relativt mye forskning om enslige forsørgeres situasjon på 1980og tidlig 1990-tallet. Det hadde blant annet sammenheng med at kvinners rolle var i endring. Det var spesiell interesse for enslige forsørgere både fordi eventuelle problemer med å forene lønnet arbeid og omsorg for barn for denne gruppen ble ansett for å være særlig utfordrende, og fordi dette var en familieform som ble vanligere, vesentlig på grunn av flere samlivsbrudd.

Som nevnt innledningsvis fikk Norge en egen stønadsordning for enslige mødre på 1960-tallet. På 1980-tallet var støtten på sitt mest generøse, og omfattet alle grupper enslige mødre og fedre fra 1981. Overgangsstønaden ga enslige mødre mulighet til å være hjemme med barn, og kunne ytes til barna var ca. 10 år, og var en garantert minsteinntekt for gruppen. I tillegg til overgangsstønad kunne en få støtte til barnetilsyn om 
en tok utdanning eller hadde lønnet arbeid. Samtidig var barnehagedekningen lav, og SFO-tilbudet ikke utbygd, så valgmulighetene var ikke nødvendigvis til stede. Enslige forsørgere ble riktignok ofte prioritert når det gjaldt slike tilbud. Overgangsstønaden var en populær stønadsordning i den forstand at den ble brukt. $70 \%$ av de som hadde muligheter til det, mottok denne stønaden på 1980-tallet. Terum (1993) gjennomførte en undersøkelse som omfattet et tilfeldig utvalg av alle som sluttet å motta overgangsstønad i perioden 1. juli 1989 til 30. juni 1990. Opplysninger ble samlet inn ved et registreringsskjema som ble utfylt av trygdekontorene rundt om i landet. Terum fant at mange som mottok full overgangsst $\varnothing$ nad, måtte supplere trygden med sosialhjelp. Gjennomsnittstiden på stønad var 3 år, og halvparten mottok støtte mindre enn 2 år. Bare $15 \%$ hadde støtte i 6 år eller lenger. Det var heller ikke vanlig å ha flere stønadsperioder, og bare $3 \%$ hadde mottatt stønad i tre perioder. Terum konkluderte med at stønaden fungerte etter intensjonen som hjelp i en overgangsperiode. Terum fant også at endret familiesituasjon, og ikke lønnet arbeid, var den sentrale grunnen til at eneforsørgere sluttet å motta overgangsstønad, og han påpekte at det var viktig å se på samspillet mellom familie, arbeid og trygd. De enslige forsørgerne som kombinerte lang stønadsperiode med utdanning, var de som klarte seg best, i den forstand at de i størst grad var i stand til å forsørge seg selv etterpå.

Hagens bekymring var at noen utnyttet ordningene, og gjorde det å få barn til en levevei. Forskningen støttet på ingen måte opp om dette. Det var få som hadde flere perioder som enslige forsørgere, og generelt var det ikke slik at enslige forsørgere var mer hjemme med barn enn andre mødre. Det var heller slik at stønadsordningene gjorde det mulig for enslige forsørgere å være like mye hjemme som andre. Beregninger som tok hensyn til både yrkes- og utdanningsaktivitet, viste at enslige forsørgere og samboende/gifte mødre i omtrent like stor grad var yrkesaktive eller i utdanning på 1980- og 1990-tallet (Kjeldstad \& Rønsen, 2002, tabell 5.15, s. 86). Når det gjaldt utviklingen over tid, fant de at yrkesaktiviteten hos gruppene var omtrent lik (ca. 6o \%) ved inngangen til 1980-tallet, men at enslige mødre som var yrkesaktive, hadde lengre arbeidstid. På 1980-tallet steg yrkesaktiviteten generelt for begge gruppene, mens den på 1990-tallet økte for gifte/samboende mødre, mens den var stabil for 
enslige forsørgere. Hovedkonklusjonen til Kjeldstad og Rønsen var at det så ut til at endringene i stønadsordningen hadde lite å si for enslige forsørgeres yrkesaktivitet, mens konjunkturene på arbeidsmarkedet hadde stor betydning. De bygde dette på at enslige forsørgere så ut til å være mer utsatt for arbeidsløshet i lavkonjunkturperioder. Problemene på arbeidsmarkedet ble også bekreftet av andre undersøkelser (Fjær \& Syltevik, 2002, s. 74; Kjeldstad \& Skevik, 2004).

\section{Politikkendring - reformen i 1998}

Uavhengig av hva som var situasjonen for enslige forsørgere, utviklet det seg en ny problemforståelse utover på 1990-tallet blant flertallet av politikerne. I korte trekk gikk den ut på at ordningene for enslige forsørgere var for generøse, at de ikke ga tilstrekkelig insentiv til å forsørge seg selv, og at det ikke var rimelig å gi slik ubetinget støtte til omsorg for egne barn. En var bekymret for velferdsstatens manglende bærekraft. Det store politiske prosjektet i denne perioden var å støtte lønnsarbeidende mødre og fedre. Vi fikk betydelig utvidelse av foreldrepermisjonsordningene, og barnehageutbyggingen skjøt fart. Det ble dermed satt spørsmålstegn ved om enslige forsørgere som gruppe trengte en egen stønad for å ivareta sine omsorgsoppgaver. I en analyse av utredninger og stortingsdebatter om velferdsordninger for enslige forsørgere i perioden 1967-1998 konkluderte jeg med at oppfatningen av det å være alenemor hadde gått fra å være relasjonell til individualisert (Syltevik, 1999). Mens omsorg for barn tidligere ble ansett som noe som krevde innsats hjemme og som et relasjonelt forhold mellom mor og barn, blir dette etter hvert definert som noe som ikke hindret full yrkesdeltakelse utover en kort periode. Det betyr at alenemødre ikke skulle trenge mer støtte enn andre foreldre, utover en kort overgangsperiode. En annen hovedlinje var endringene i synet på støtte fra velferdsstaten til gruppen. Mens det på 1960-tallet ble sett på som rimelig at velferdsstaten gikk inn og erstattet forsørgelse gjennom ekteskap, var det dominerende synet på 1990-tallet at offentlig forsørgelse skapte avhengighet og passivitet. I tillegg ble situasjonen til enslige mødre nå speilet mot nye familieidealer: en toinntektsfamilie der begge er i full jobb, og barna i barnehager på dagtid. Normen om 
alenemødres individuelle plikt til å forsørge seg selv på arbeidsmarkedet var klart forsterket.

Den store endringen i støtteordningene for enslige forsørgere kom i 1998. Samlet sett ble det etablert en ny ramme for det offentliges ansvar i denne livssituasjonen. Målet var å øke enslige forsørgeres utdanningsog yrkesaktivitet for å bidra til at de ble selvforsørgende. I tillegg var det viktig, mente man, å forhindre passivisering og permanent avhengighet av offentlig forsørgelse. Virkemidlene for å oppnå dette var dels tiltak for å oppmuntre til lønnet arbeid eller utdanning (bedret nivå på stønaden til barnetilsyn, en brukermedvirknings- og oppfølgingsordning). Friheten til selv å bestemme kombinasjonen av arbeid, utdanning og omsorg ble nå forbeholdt dem som hadde barn under 3 år. Etter den tid ble det stilt krav om «aktivitet» (forstått som lønnet arbeid, utdanning eller søking på lønnet arbeid), og stønadstiden ble som hovedregel satt til maks 3 år. Etter reformen ble altså enslige forsørgere underlagt et regime som var likestillingsorientert, samtidig som kontantstøtten ble innført, med formålet å gjøre kombinasjonen omsorg for barn og lønnet arbeid mer fleksibel for toinntektsfamilier. Fjær og Syltevik (2002) betegnet det derfor som at enslige forsørgere var sendt ut som frontløpere for likestillingen. Nå «passet» forestillingen om velferdsavhengighet, koblingen av omsorg for barn med passivitet og oppfatningen av slik omsorg som unødvendig, inn i en mer generell endring i oppfatningen av enslige forsørgeres situasjon i velferdsstaten. Hagen fikk dermed gjennomslag for sine løsninger et tiår etter.

Reformen hadde stor virkning, og antall mottakere ble halvert fra et år til det neste. Fjær og Syltevik (2002) fant i en surveyundersøkelse at halvparten av de som ikke lenger hadde overgangsstønad i 2001, var i fulltidsarbeid, mens $40 \%$ hadde lang eller kort deltid. Flere kom i lønnet arbeid, men økonomisk var det bare en fjerdedel som hadde et inntektsgrunnlag som var rimelig i forhold til selvforsørgelse. En tredjedel hadde problemer med å klare løpende utgifter, mens to tredjedeler oppga problemer med uforutsette utgifter. Når kvinnene selv skulle bedømme hva som var til hinder for å klare å forsørge seg selv, var det fire forhold som dominerte: 1) at de arbeidet i lavtlønnsyrker, 2) manglet utdanning, 3) strevde med å kombinere omsorgsarbeid og lønnsarbeid, og 4) at stønadsperioden var for kort til å skape et godt grunnlag for selvforsørgelse. 
Rikstrygdeverket undersøkte også konsekvensene av reformen ved hjelp av registerdata (Kristoffersen, Haabeth, Gaardsrud \& Thune 2006). Konklusjonen var, som hos Fjær og Syltevik, at flere kom i arbeid og utdanning, men at dette ikke betydde at alle var selvforsørget. $16 \%$ mottok for eksempel økonomisk sosialhjelp eller stønad til attføring/rehabilitering. Bare halvparten av alle som avsluttet perioden med overgangsstønad i perioden 1998-2003, hadde heltids- eller deltidsarbeid (48 \%), mens $17 \%$ var arbeidssøkende og $15 \%$ hadde andre trygdeytelser. Konklusjonen var dermed at de svakest stilte hadde betydelige overgangsvansker, og at andelen med lønnet arbeid ikke var vesentlig større etter 2 år. Mogstad og Pronzato (2012) hadde tilsvarende funn når de sammenlignet enslige forsørgere, kvinner uten barn og samboende gifte kvinner med barn i alderen 4-9 år ved hjelp av registerdata. Forskningen på konsekvensene av reformen er dermed relativt entydig. Arbeidsmarkedsdeltakelsen økte, men en betydelig andel av gruppen fikk mindre inntekt og økt risiko for fattigdom. Til tross for relativt gunstig situasjon på arbeidsmarkedet hadde mange enslige forsørgere vanskelig med å få lønnet arbeid eller så mye lønnet arbeid som de ønsket. Nedskjæringene hadde store omkostninger for den svakeste gruppen.

\section{Nye myter - innvandrermødrene og den generøse norske velferdsstaten}

I årene etter har vi hatt mange debatter i media og blant politikere om trygdemisbruk, betydningen av økonomiske insentiver, om arbeidslinje, trygdeavhengighet og passivitet, og om vi har for generøse ordninger generelt. Oppfatninger om at trygd «smitter», at stønader skaper avhengighet, og at det er et stort misbruk av offentlige stønader, har vunnet terreng (se Vogts artikkel i boken). Alenemødre og enslige forsørgere har mer og mer forsvunnet fra offentligheten som generell sosialpolitisk kategori (Grødem, 2016). Derimot har mye av det offentlige ordskiftet handlet om kvinner med migrasjonsbakgrunn som er hjemme med barn og dermed ikke blir integrert i samfunnet. De store offentlige debattene etter 2000 som har dreidd seg om enslige mødre, har også handlet om denne problemstillingen. Her er det kvinner med bakgrunn fra Somalia som 
har blitt identifisert med misbruk av stønadene til enslige forsørgere, ved å skille seg fiktivt fra barnefedrene, som har vært hovedpersonene. Første runde av denne debatten kom rundt 2007, og den siste i 2010/11.

Den første debatten hadde utgangspunkt i medieoppslag om det såkalte Somalia-prosjektet 2004-2005 (Engebrigtsen \& Farstad, 2004). Rapporten anga flere årsaker til behov for trygde- og stønadsordninger: analfabetisme og lite eller ingen skolegang, mangel på jobb, press for å sende penger til Somalia og familier med mange barn. Rapporten la vekt på ulikhetene innad i gruppen, og advarte mot stigmatisering og stereotypier. De ansatte i velferdsetatene som ble intervjuet, var opptatt av å nyansere bildet av gruppen. Fagbladet Velferd presenterte rapporten i $2007 \mathrm{og} \mathrm{skrev} \mathrm{da} \mathrm{at}$ trygdemisbruk var godt kjent i de somaliske miljøene. Det ble også referert til at representanter fra moskeene mente at det var et problem. I andre medier ble overskriften «Alenemødre svindler med trygden» (Karlsen, 2007) brukt. Det ble slått stort opp at trygdesystemet avdekket et økende stønadsmisbruk blant somaliske mødre, og at de skilte seg etter norsk lov, men fortsatte å være gift etter muslimsk. Lederen av NAV kontroll ble sitert på at de hadde hatt flere slike saker til behandling. I et debattfelt i VG med tema «Trygdesvindel hos norsk-somaliske kvinner» ble det i flere innlegg hevdet at det var mye misbruk - og at den norske velferdsstaten var truet og ble lurt trill rundt (VG debatt, 2007).

I 2010 kom den samme debatten om igjen etter at Kadra Yusuf skrev en kronikk i VG 18. august, der hun hevdet at somaliske kvinner skiller seg etter norsk lov, men fortsetter å være gift etter islamsk for å få økonomisk støtte selv om de reelt bor sammen med barnefaren. Hun ville peke på at det norske velferdssystemet oppfordrer ektepar til å skille seg og premierer alenemødre med store barneflokker. Kadra Yusuf fikk motbør fra det somaliske miljøet. Lederen for Somalisk nettverk, Bashe Musse, advarte mot stigmatisering av en hel gruppe. Han viste til at det er mange grunner til at parforhold i Norge blant somaliere går i stykker. Det er vanskelig å få lønnet arbeid i Norge, og mange utfordringer som bidrar til samlivsbrudd. Han etterlyste også dokumentasjon på påstandene (Flågen, 2010; Helmers, 2010). I januar 2011 kom det en rapport fra Frischsenteret, som ble presentert av TV2 under overskriften «Somaliske kvinner på trygdetoppen» (TV2, 2011). Tre av fire somaliske kvinner hadde mottatt 
overgangsstønad i en periode, og både forskeren (Knut Røed) og SVpolitikeren Heikki Holmås uttalte at ordningene med overgangsstønad og kontantstøtte burde endres. Under overskriften «Nær halvparten av alle barn av somaliske mødre er født utenfor ekteskap» (Det samme gjelder for øvrig generelt for barn født i Norge!) meldte NRK.no 9. mars 2011 at politiet hadde gått til aksjon mot flere somaliske barnefamilier i Oslo som var siktet for grovt trygdebedrageri. NRK fulgte opp med et oppslag med tittelen: «10o somaliske kvinner fikk barn med eksmannen», og direktør i NAV kontroll Magne Fladby uttalte at de kjente til ca. 100 kvinner som hadde fått barn med tidligere ektefelle med bakgrunn fra Somalia, som søkte stønad som enslig mor. Aksjonen til politiet dreide seg om fire somaliske familier. En lignende aksjon var gjennomført i Rogaland tidligere på året og resulterte $\mathrm{i}$ at 22 personer ble siktet (Solvang \& Tunheim, 2011). Debatten kom også opp i Stortinget. Tirsdag 12. april 2011 tok Robert Eriksson (da stortingsrepresentant for FrP, senere arbeidsminister for Solberg-regjeringen) initiativ til en interpellasjon i Stortinget og stilte daværende statsråd Audun Lysbakken følgende spørsmål: «Hvordan vil statsråden stimulere somaliske innvandrere ut av rollen som passive stønadsmottakere med dårlige familieforhold og inn i inntektsgivende arbeid, og er statsråden villig til å angripe problemet ut fra en kulturell synsvinkel?» (Stortinget, 2011). Det etablerte seg en oppfatning om at dette var et omfattende problem. Dette er også framhevet i offentlige utredninger:

Bruken av overgangsstønad akkurat i denne innvandrergruppen framheves flere ganger som problematisk. Det hevdes at adgangen til stønad som enslig forsørger undergraver den somaliske familien, at ektepar i praksis oppfordres til å skilles av økonomiske grunner og at en del par også skiller seg fiktivt (og forblir gift etter islamsk lov og i realiteten bor sammen) for å få tilgang til disse stønadene. Som vist i kapittel 9, er forbruket av overgangsstønad høyt i en del innvandrergrupper, særlig blant kvinner fra Somalia (NOU 2011:7, 2011, s. 333).

Da det på høsten 2011 ble meldt at en somalisk nibarnsmor hadde svindlet NAV og Bærum kommune for 1,4 millioner kroner og fått fengselsstraff, lot ikke reaksjonene i kommentarfeltene vente på seg. Dette var ikke overgangsstønad, men rehabiliterings- og arbeidsavklaringspenger. 
I nettdebatten som fulgte saken på nettstedet frieord.no (Frieord, 2011), er det kommentarer som dette:

Leste om det i Dagbladet, men der unnlot de selvsagt å si at hun var somalisk, men etter flere års erfaring med innvandrere visste jeg det likevel. Alle visste det.

Ni forbainna unga har hun klemt ut, enorme summer i barnetrygd, sosialstønad for kjærringa, og ungene belaster politi, kriminalomsorg og nav i all sin levetid. Vanlige norske familier må jobbe for pengene.

Hele kullet hennes på ni unger er sannsynligvis allerede i NAV-kø, klare til å bli finansiert av deg og meg for å drive gatelangs (Frieord, 2011).

Etter 2011 har det vært lignende oppslag. Holdningene hos NAV-ansatte er også tydelig endret $\mathrm{i}$ forhold til det positive bildet som ble tegnet $\mathrm{i}$ Somaliaprosjektet. Under overskriften «Slik svindler unge jenter Norge» gjengis funn fra en rapport fra Proba analyse slik: «Alenemødre er landets største trygdesnyltere og aller verst er unge jenter og innvandrere. Hver fjerde utbetalte krone kan være svindel» (Solberg, 2013). Denne rapporten baserer seg på hva NAV-ansatte trodde om trygdesvindel, ikke av faktiske dokumenterte tilfeller.

\section{Forskningen om enslige forsørgere etter $\mathbf{2 0 0 0}$}

Hva sier så forskningen om enslige forsørgeres situasjon etter 200o? Epland og Kirkenær (2016) finner for det første at yrkesaktiviteten i kategorien enslige forsørgere er lite endret fra 2004-2013. Dette til tross for at dette har vært en periode med gode forhold for sysselsettingen (lav arbeidsledighet og oppgangstid). Det kan være mange grunner til dette. De har blant annet ikke data for hvor mange som tar utdanning, og denne andelen kan ha økt. Når det gjelder enslige forsørgere og trygd, har innvandrermødre faktisk en litt gunstigere utvikling enn andre mødre med hensyn til yrkesaktivitet etter stønadsmottak. Kavli, Nielsen og Sandbæk (2010) fant at det var flere ikke-vestlige mottakere av overgangsstønad enn norske som går over i lønnet arbeid etter endt periode med overgangsstønad. De påpeker også at samlet sett har tidligere mottakere av overgangsstønad (med og uten innvandringsbakgrunn) høyere sysselsetting 
enn andre kvinner med samme alder, utdanning og bosted (Kavli et al., 2010, s. 86). Ellers framhever forskerne at innvandreralenemødre er mer like enn forskjellige fra enslige forsørgere med norsk bakgrunn. De er kvinner, omtrent like gamle og har støtte omtrent like lenge. De med innvandrerbakgrunn har litt flere barn, mindre arbeidsmarkedserfaring og utdanning.

Når det gjelder økonomisk situasjon for barnefamilier i Norge er hovedbildet at husholdningene har hatt en svært gunstig inntektsutvikling de siste tiårene (Epland \& Kirkeberg, 2014). Men blant de med svakest vekst finner vi småbarnsfamilier, enslige forsørgere, barnerike familier og hushold med voksne med svak tilknytning til arbeidsmarkedet. Andelen med barn i lavinntektshushold har også økt i perioden. Lavtinntektshushold er hushold som har hatt lav inntekt i minst tre år. Lavinntektsgruppen har også endret demografisk sammensetning, og innvandrere og enslige forsørgere utgjør nå en større andel. Sjansen for å tilhøre de laveste inntektsklassene var henholdsvis 11 og $15 \%$ for par med barn i 2000 og 2013, mens for enslige forsørgere var sjansen 30 og $47 \%$ (Epland \& Kirkeberg, 2014). Det har også vært en kraftig økning i andelen med innvandrerbakgrunn blant alle barn med foreldre med vedvarende lavinntekt. Mens dette gjaldt 39 \% i perioden 2004-2006, utgjør de mer enn halvparten i perioden 2012-2014 (NOU 2017: 6, s. 121). Også det å tilhøre kategorien enslig forsørger slår negativt ut (Kaur, 2013). Sannsynligheten var tre ganger så høy for at barn som bor med enslig mor eller far, skal tilhøre lavinntektsgruppen, sammenlignet med parhusholdninger. Enslige forsørgere har også dårligere boligstandard enn barnefamilier generelt (Revold, 2018). Halvparten av alle enslige forsørgere har høye boutgifter, mens dette gjelder bare $16 \%$ av alle par med barn. Antall enslige forsørgere med sosialhjelp har gått ned i perioden 2002-2012 (Tønseth, 2014). Samtidig har enslige forsørgere med sosialhjelp i større grad dette som hovedinntekt. Mens $29 \%$ av sosialhjelpsmottakerne hadde innvandrerbakgrunn i 2002, gjaldt dette $52 \%$ i 2012. Konklusjonen til Tønseth er at kombinasjonen å være innvandrer, ha aleneansvar for barn og lav utdanning gjør det vanskelig å skaffe seg annen inntekt.

Somaliske mødre skiller seg ut ved å være enslige forsørgere i større grad enn andre innvandrergrupper. De har også i større grad mottatt 
støtte som enslige forsørgere enn andre innvandrergrupper, og i større grad enn alenemødre med norsk bakgrunn. Samtidig er heller ikke forskjellene så store når en tar utfordringene med å emigrere fra et land til et annet med i betraktning. I gruppen enslige mødre som kom fra Somalia i perioden 1988-2000, hadde $52 \%$ slik støtte, sammenlignet med 40 $\%$ blant norske enslige mødre i samme aldersgruppe med lav utdanning (Bratsberg, Røed \& Raaum 2011).

Mange forskere har forsøkt å nyansere og korrigere bildet av det somaliske miljøet og somaliske mødre. Katrine Fangen utga en bok i etterkant av den første debatten basert på feltarbeid i det somaliske miljøet (Fangen, 2008). Hun la blant annet vekt på at arbeidsløshet blant menn er en skam i det somaliske miljøet, og la vekt på hvor stor ulikhet det var i gruppen. I et intervju med Aftenposten uttalte hun: «Også blant kvinnene er det mange som ønsker seg jobb, men ikke får det. Men jeg har også truffet på somaliske kvinner som er forundret og provosert over at det norske samfunnet forventer at de skal jobbe. Mange somaliere har sju-åtte barn, og det å ta seg av disse framstår som jobb nok» (Wang-Naveen, 2008). I kjølvannet av den siste debatten har forskere lagt vekt på det norske velferdsbyråkratiets manglende evne til å bidra til somaliere. Møtet med NAVs tiltaksapparat oppleves som ydmykende og vilkårlig (Friberg \& Elgvin, 2016). Forskerne som har arbeidet med introduksjonsprogrammet, har også vært kritiske til treffsikkerheten av tiltakene (Djuve, Kavli \& Hageland, 2011).

Mens mediedebatten kan få en til å tro at alenemødrene blant innvandrerne er svært forskjellig fra enslige forsørgere generelt, ser det i stedet ut til at både somaliske mødre og andre innvandreralenemødre har problemer som de deler med de svakest stilte alenemødrene med norsk bakgrunn: vanskeligheter med å få lønnet arbeid, helseproblemer og omsorgsforpliktelser. Det er heller ikke noen dokumentasjon på at innvandrermødre i større grad misbruker trygdesystemet enn andre. NAV kontroll har ikke statistikk etter etnisitet, så dette er vanskelig å verifisere, men i den grad pressen har fått tak i saker der enslige forsørgere faktisk er dømt, har dette både vært kvinner med norsk og utenlandsk bakgrunn. Likevel har det negative bildet av somaliere festet seg, og dette er også noe de forholder seg til. I et innlegg i Klassekampen 25. mars 2017 forsvarte Safia Abdi Haase (2017), en norsk-somalisk sykepleier, seg mot denne 
typen oppfatninger i et debattinnlegg med overskriften «Trygdedronninger?». Hun peker der på hvordan normene i Somalia skiller seg sterkt fra de norske med hensyn til forholdet mellom kjønnene, og hun ber om respekt for at dette kan være krevende. Hun peker også på at mange ikke har fått muligheter til å utdanne seg og komme ut i arbeidslivet. Hun konkluderer: «Mitt ønske er at vi lar være å bruke negative begrep som «trygdedronning», som lett kan generaliseres og ramme uskyldige som gjerne vil bidra positivt i samfunnet» (Abdi Haase, 2017, s. 43).

Bildet av innvandrermødre som kvinner med helt andre holdninger enn kvinner generelt, og som en trussel mot velferdsstaten, er også en kombinasjon av en bestemt type problemforståelse, en oppfatning av en løsning koblet med bredere samfunnsideer (jf. Metha, 2010). Hovedfortellingen om mødrene med migrasjonsbakgrunn er at de velger å være hjemme med barna og ikke vil bli integrert. Løsningen er å ikke lenger gi støtte slik at de må ut på arbeidsmarkedet og bli integrert. Dette er knyttet til ideer om likestilling, integrering og den enkeltes ansvar for å klare seg selv. Mytene om innvandrermødrene passer dermed også inn i mange andre sentrale ideer om velferdsstaten i vår tid.

\section{Politikkendringene i 2010-årene}

Utover i 2000-årene og 2010-årene kom det en rekke endringer i stønadsordningene for enslige forsørgere, slik at vi i dag sitter igjen med en svært begrenset stønadsordning. Endringene har i stor grad blitt gjort som en del av budsjettforhandlingene i Stortinget, og de har derfor i liten grad blitt offentlig debattert i forkant. Grensen for barns alder på 3 år som kom i 1998, er nå erstattet med en grense på 1 år. Det er dermed bare det første året enslige forsørgere kan få overgangsstønad for å være hjemme på heltid. Etter det må de enten være i arbeid, utdanning eller være arbeidssøkende. Enslige forsørgere som får overgangsstønad, må være villige til å ta ethvert lønnet arbeid med vanlige lønnsbetingelser, med inntil én times reisetid hver vei, arbeide minst $50 \%$ av full tid og delta på arbeidsmarkedstiltak. Det er mulig å reservere seg mot kvelds-, natt- og helgearbeid. Maksimal stønadstid er fortsatt 3 år. Det er også satt begrensinger i antall 3-årsperioder det er mulig å få, og når det gjelder å få barn med samme 
partner. Regelverket sier nå at om en får et barn til med samme partner, så har en ikke rett til støtte som enslige forsørger for dette andre barnet (endringen ble iverksatt 1. januar 2016). Dette var en endring som direkte er rettet mot å unngå misbruk av stønaden gjennom at noen foreldre skiller seg proforma for å få ytelser, som vi har sett at mediedebatten presenterte som et stort problem. Andre endringer er at samboerskap (også med annen enn barnas andre foreldre) diskvalifiserer for stønad fra første dag (også med virkning fra 2016).

Grødem (2017) har diskutert hvilken betydning migranters bruk av ytelser har hatt for de familievennlige stønadene i Skandinavia. Hun finner at migrasjon ble brukt som et av flere argument ved endringen til 1 års alder som grense for full overgangsstønad, men at den daværende rød-grønne regjeringen la vekt på at betydningen av å gå ut i arbeidslivet var like stor for alle enslige forsørgere. Hovedargumentet var at det nå var lettere for alle foreldre å være ute i arbeidslivet med små barn, med et godt barnehagetilbud og bedre foreldrepermisjonsordninger. Grødems konklusjon er at migrasjonsargumenter slår inn avhengig av hvilke støtteordninger en har i utgangspunktet, og hvilke andre argumenter som er i spill. Overgangsstønaden hadde få «venner» og var kontroversiell i utgangspunktet, mens det stilte seg noe annerledes for kontantstøtten. Her slo ikke migrasjonsargumentasjonen igjennom, siden denne ordningen, selv om den var kontroversiell, også hadde sterke støttespillere. Dermed vant argumenter om valgfrihet og barns behov for fleksibilitet. Grødem konkluderer i tillegg med at migrasjonsargumentasjon ofte nedtones av politikerne. Når det gjelder endringene i stønadsordningene som kom etter 2000, er i liten grad migrasjon nevnt, mens det er forsterkning av arbeidslinjen og forenkling som framheves (Arbeids- og sosialdepartementet, 2015). Dette gjelder også den endringen at en ikke lenger får støtte om en får barn med samme partner. Endringen ble reist som benkeforslag i Stortinget 11. juni 2015 på vegne av Høyre, Fremskrittspartiet og Kristelig Folkeparti. Argumentet som ble framsatt av forslagsstiller og saksordfører Stefan Heggelund, var at dette ville gjøre ordningen mer treffsikker (Stortinget, 2015).

I dag er kategorien som får disse stønadene, avgrenset og regelverket komplisert. For å få ytelser vil det være kontroll av mange forhold som 
griper inn i privatlivet, som forholdet til kjærester, den andre forelderen, aktivitet når det gjelder lønnet arbeid og fordeling av tid med barn mellom foreldrene. Prisen i form av kontroll ved å motta disse stønadene er dermed svært høy.

\section{Virksomme myter, politikk og forskning}

Stereotypiene om alenemødrene i mediedebattene på slutten av 1980årene og etter 2000 har flere likhetstrekk. Det dreier seg om kvinner som har omsorg for barn, og som mottar stønader fra det offentlige. I begge tilfellene handler det om kvinner med omsorg for barn som antas å «velge bort» lønnsarbeid på grunn av generøse velferdsordninger og tradisjonelle holdninger. Framstillingene har også til felles at det stilles spørsmål ved ansvarligheten ved å sette barn (eller så mange barn) til verden uten å kunne forsørge dem selv, og at omsorgen for barn ikke regnes som et arbeid. Det er også ideer om misbruk inne i bildet, enten det handler om å ikke ha de riktige holdningene og ikke ønske lønnet arbeid, eller det handler om å ikke reelt tilhøre målgruppen. Det er også et fellestrekk at stereotypiene presenterer kvinnene som en trussel mot velferdsstaten.

Det er også ulikheter. En forskjell er at framstillingen i årene etter 2000 på 2000- og 2010- tallet er knyttet til migrasjonsbakgrunn, og at etnisk bakgrunn framheves. En annen er at debatten på 1980-tallet var et politisk utspill fra lederen i et parti på høyre fløy i en valgkamp, etter alt å dømme med sikte på å få medieoppmerksomhet ved å bruke denne trygdeordningen og dette kvinnebildet som utgangspunkt. I den senere debatten er det et mer komplisert samspill mellom forskning, politikk og media. Debattene tar utgangspunkt i presentasjon av forskning, og deltakerne er media, politikere fra ulike partier og forskere. I tillegg er representanter fra migrantmiljøet sentrale i debatten. Det er mange kunnskapsformer representert, og her er stereotypien mer det gjennomgående bildet som debatten kretser rundt.

Stereotypiene i begge perioder stemmer i liten grad med det generelle bildet som forskning tegner av gruppen. På 1980-tallet var det ikke slik at enslige mødre hadde mindre lønnet arbeid og utdanning enn andre mødre, og overgangsstønaden bidro positivt til at enslige mødre kunne ta 
utdanning. Etter 2000 er situasjonen til somaliske mødre ikke så forskjellig fra situasjonen til andre enslige forsørgere og enslige mødre, og noe omfattende trygdemisbruk er ikke avdekket. Stereotypier er imidlertid vanskelig å tilbakevise. Det kan alltid bli satt fram påstander om enkeltpersoner som passer med myten. Når disse enkeltsakene gås etter i sømmene, viser det seg at bildet er atskillig mer nyansert enn det som kommer fram i media (se Dencker-Larsen \& Lundberg (2016) og Vogts artikkel i denne boken). Dette gjelder også trygdemisbruk. Som Håhjem (2012) konkluderer i sin analyse av dommer for trygdemisbruk, er de dømte folk med få økonomiske alternativer og vanskelige livssituasjoner på mange områder.

Forskning på ideer og politikk har vist hvilken betydning kampen om ideer har for hvordan problemer forstås, og hvilke løsninger som vinner fram. Virkningen av stereotypier og myter er mindre studert. Hedegaard (2014) har undersøkt hvordan to negative debatter i Danmark, konsentrert om 'fattige Carina' (en dansk enslig mor) og 'late Robert', virket på holdningen til sosialhjelp. Panelstudien viste at de negative holdningene ble litt styrket, men at hovedvirkningen var at det skjedde en polarisering mot sterkt negative og sterkt positive holdninger på individnivå. Hedegaard konkluderer med at endringene i politikken som fulgte, likevel var betydelige. Siden disse politikkendringene ikke kunne skyldes endringer i opinionen, peker han på at en må se til andre mulige forklaringer, som politiske muligheter og paradigmeskifter i synet på arbeidsledige. En annen mulighet er at selve debatten stiller spørsmål ved legitimiteten til ordningene, og bidrar til at politikerne går inn for endringer. Virkningen av stereotypier er dermed ikke enkel, men både direkte og indirekte og inngår i kamper om hvordan virkeligheten forstås.

Hvilken betydning har mytene om uansvarlige alenemødre og snyltende innvandrermødre hatt på politikken på området? Jeg vil hevde at dette har vært virksomme myter i den forstand at de har satt dagsorden og bidratt til politikkendringer som har vært i tråd med slike forstillinger (jf. Christensens diskusjon av forestillinger om aldring i denne boken). Stereotypien på 1980-tallet hadde en slik dagsordenfunksjon. Hagens framstilling av enslige mødre fikk liten støtte, men ga en bestemt inngang til diskusjonen om stønadsordningene for gruppen. Når det gjelder debattene om de somaliske kvinnene etter 2000, satte stereotypien 
dagsorden for hva ved stønadsordningene det var viktig å diskutere. Om disse debattene fikk innvirkning på politikkutformingen, avhang imidlertid av styrken til andre argumenter, og migrasjonsargumentene ble oftest ikke brukt direkte.

Det at myter kan virke, gjør det svært viktig at forskere ivaretar sin oppgave med å ikke ta myter og stereotypier for gitt, men utforske og utfordre dem. En virkning av at disse stereotypiene har satt dagsorden, er at andre sider ved enslige forsørgeres og innvandrermødres situasjon har fătt mindre oppmerksomhet enn de ellers kunne fått. Det har vært lite fokus på mer allmenne spørsmål, som hva det innebærer å ha omsorg for barn alene i dag, og hvilke stønadsordninger som trengs. Det har også vært lite forskning på kategoriens situasjon de senere årene. Det å være enslig med barn handler blant annet om det å være eninntektshushold i et samfunn der toinntektsfamiliene dominerer (Fjær \& Syltevik, 2002; Grødem 2016; Syltevik, 1996; Syltevik, 2015). Det å skulle stå for boutgifter og levekostnader i en husholdning med én inntekt, vil særlig være krevende for de med lavest inntekt, og klasseforskjeller kommer også inn. Dette kan være utfordrende for enslige mødre enten de har norsk eller annen bakgrunn.

\section{Sluttnoter}

1. Størrelsen på gruppen alene med barn er avhengig av hvordan kategorien avgrenses. Det er en livsfase som enten ender ved at barn blir voksne og flytter hjemmefra, eller ved at en finner en ny partner og får flere barn. Andelen i befolkningen som har opplevd denne livsfasen, vil være langt større enn de som til enhver tid er i situasjonen. Gruppen vokste fra 1970-tallet med økningen i samlivsbrudd. Det å motta ekstra barnetrygd har vært det mest pålitelige anslaget ettersom denne stønaden gis til personer som har hovedomsorgen for barn under 18 år. I 2018 gjaldt dette 121570 personer og 18 \% av mottakerne av barnetrygd. Nå er dette tallet mindre dekkende for omfanget enn tidligere, ettersom flere velger delt omsorg slik at de ikke kvalifiserer til denne stønaden.

\section{Referanser}

Abdi Haase, S. (2017, 25. mars). Trygdedronninger. Klassekampen, Meninger, s. 45. Arbeids- og sosialdepartementet (2015). Endringer i folketrygdloven mv. (stønader til enslig mor eller far og tilleggsstønader til tiltaksdeltakere) (Prop. $115 \mathrm{~L}$ 
(2014-2015). Hentet fra https://www.regjeringen.no/no/dokumenter/prop.115-1-2014-2015/id2409869/

Bacchi, C. (1999). Women, Policy and Politics: The construction of Policy Problems. London: Sage.

Beland, D. \& Cox, R.H. (Red.). (2010). Ideas and politics in social science research. Oxford: Oxford University Press.

Bratsberg, B., Røed, K. \& Raaum, O. (2011). Yrkesdeltaking på lang sikt blant ulike innvandrergrupper i Norge (Stiftelsen Frischsenteret for samfunnsøkonomisk forskning Rapport 1/11). Hentet fra https://www.digiblioteket.no/files/get/DgK/ rapp11_01.pdf

Dencker-Larsen, S. \& Lundberg, K.G. (2016). Depicted welfare recipient sterotypes. A photo-elication study. Nordic Journal of Social Research, 7. https://doi. org/10.7577/njsr.2098

Djuve, A.B., Kavli, H.C. \& Hagelund, A. (2011). Kvinner i kvalifisiering. Introduksjonsprogram for nyankomne flyktninger med liten utdanning og store omsorgsoppgaver. (FAFO Rapport 2/11). Hentet fra https://www.fafo.no/index. php/zoo-publikasjoner/fafo-rapporter/item/kvinner-i-kvalifisering

Duncan, S. \& Edwards, R. (1999). Lone mothers, paid work and gendered moral rationalities. London: Macmillan press ltd.

Engebrigtsen, A. \& Farstad, G.R. (2004). Somaliere i eksil i Norge. En kartlegging av erfaringer fra fem kommuner og åtte bydeler $i$ Oslo (NOVA Skriftserie 1/o4). Hentet fra http://www.hioa.no/Om-OsloMet/Senter-for-velferds-ogarbeidslivsforskning/NOVA/Publikasjonar/NOVAs-skriftserie/2004/Somaliere-ieksil-i-Norge

Epland, J. \& Kirkeberg, M.I. (2014, 18. mars). Flere innvandrerbarnefamilier med lavinntekt. (Statistisk sentralbyrå (SSB) Artikkel) Hentet fra https://www.ssb.no/ inntekt-og-forbruk/artikler-og-publikasjoner/flere-innvandrerbarnefamiliermed-lavinntekt

Epland, J. \& Kirkeberg, M.I. (2016, 6. april). Barnefamiliers inntekter, formue og gjeld. 2004-2014 (Statistisk Sentralbyrå (SSB) Rapport 11/16). Hentet fra https://www. ssb.no/inntekt-og-forbruk/artikler-og-publikasjoner/barnefamilienes-inntekterformue-og-gjeld-2004-2014

Fangen, K. (2008). Identitet og praksis: etnisitet, klasse og kjønn blant somaliere. Oslo: Gyldendal Akademisk.

Fjær, S. \& Syltevik, L.J. (2002). Omsorg, tid og penger for likestillingens frontløpere. Evaluering av reformen for enslige forsørgere (Rokkansenteret Rapport 2/02). Bergen: Stein Rokkan senter for flerfaglige samfunnsstudier.

Flågen, K.T. (2010, 18. august). Kadra mistenkeliggjør og stigmatiserer somaliere. $V G$. Hentet fra https://www.vg.no/nyheter/innenriks/i/p39EE/kadramistenkeliggjoer-og-stigmatiserer-somaliere 
Friberg, J.H. \& Elgvin, O. (2016). Når velferdsstaten bryter tilliten ned: Somaliske innvandrere i møte med NAV. Tidsskrift for samfunnsforskning, 57(3), 257-284. https://doi.org/10.18261/issn.1504-291X-2016-03-02

Frieord (2011). Somalisk nibarnsmor svindlet NAV Bærum kommune for 1,4 mill. Frieord. Hentet fra https://www.frieord.no/innenriks/somalisk-nibarnsmorsvindlet-nav-og-baerum-kommune-for-1-4-millioner-kroner/ /

Grødem, A.S. (2010). Enslige forsørgere, enker og enkemenn. I A.H. Bay, A. Hatland, O. Hellevik \& C. Koren (Red.), De norske trygdene: framvekst, forvaltning og fordeling(s. 297-309). Oslo: Gyldendal Akademisk.

Grødem, A.S. (2016). Fra Castberg til Solberg: aleneforsørgernes vekst og fall i norsk sosialpolitikk. Sosiologisk tidsskrift, 24(4), 303 -326. https://doi.org/10.18261/ issn.1504-2928-2016-04-03

Grødem, A.S. (2017). Family-oriented policies in Scandinavia and the challenge of immigration. Journal of Social Policy, 27(1), 77-89. https://doi. org/:10.1177/0958928716673315

Hedegaard, T.F. (2014). Stereotypes and welfare attitudes: a panel survey of how 'poor Carina' and 'lazy Robert' affected attitudes towards social assistance in Denmark. Nordic Journal of Social Research, 5(5), 139-16o.

Helmers, A.-K. B. (2010, 18. august). Kadra Yusuf: Somaliere skiller seg, men bor sammen. VG. Hentet fra https://www.vg.no/nyheter/innenriks/i/XKz2B/kadrayusuf-somaliere-skiller-seg-men-bor-sammen

Håhjem, A.R. (2012). Registrert trygdemisbruk blant enslige forsørgere i Norge 1997-2011. Hvordan utøves kontroll $i$ et system basert på tillit og kjorlighet. (Masteroppgave). Institutt for kriminologi og rettsvitenskap, Universitetet i Oslo.

Kamerman, S.B. \& Kahn, A.J. (1988). Mothers alone - strategies for a time of change. Massachusetts: Auburn House Dover.

Karlsen, O. (2007, 27. mars). Alenemødre svindler med trygden. Abc Nyheter. Hentet fra https://www.abcnyheter.no/penger/2007/03/27/43989/alenemodre-svindlermed-trygden

Kaur, R. (Red.) (2013). Økonomi og levekår for ulike lavinntektsgrupper 2013 (Statistisk sentralbyrå (SSB) Rapport 32/13). Hentet fra https://www.ssb.no/ inntekt-og-forbruk/artikler-og-publikasjoner/okonomi-og-levekaar-for-ulikelavinntektsgrupper-2013

Kavli, H.C., Nilsen, R.A. \& Sandbæk, M.L. (2010). Stønadsordningen for enslige forsørgere. Hvordan fungerer den for mottakere med innvandrerbakgrunn? (FAFO Rapport 32/10). Hentet fra https://www.fafo.no/index.php/zoo-publikasjoner/ fafo-rapporter/item/stonadsordningen-for-enslige-forsorgere

Kjeldstad, R. \& Rønsen, M. (2002). Enslige foreldre på arbeidsmarkedet 1980-1999. En sammenligning med gifte mødre og fedre (Statistisk sentralbyrå (SSB) Statistiske 
analyser 49/o2). Hentet fra https://www.ssb.no/arbeid-og-lonn/artikler-ogpublikasjoner/enslige-foreldre-pa-arbeidsmarkedet-1980-1999

Kjeldstad, R. \& Skevik, A. (2004). Enslige forsørgere - en sosialpolitisk kategori utgått på dato? I A.L. Ellingsæter \& A. Leira (Red.), Velferdsstaten og familien. Utfordringer og dilemma (s. 231-26o). Oslo: Gyldendal Akademisk.

Kristoffersen, P., Haabeth, T., Gaardsrud, P.Ø. \& Thune, O. (2003). Enslige forsørgere etter reformen i 1998 (Rikstrygdeverket RTV Rapport 3/o6). Hentet fra https://www.nav.no/no/NAV+og+samfunn/Kunnskap/Analyser+fra+NAV/ $\mathrm{NAV}+$ rapportserie/NAV+rapporter/enslige-fors\%C3\%B8rgere-etterreformen-i-1998

McLanahan, S. (1994). The Consequences of Single Motherhood. The American Prospect. Hentet fra http://prospect.org/article/consequences

Metha, J. (2010). The Varied Roles of Ideas in Politics. From «Whether» to «How». I D. Beland \& R.H. Cox. (Red.), Ideas and politics in social science research (s. 23-46). Oxford: Oxford University Press.

Mogstad, M. \& Pronzatio, C. (2012). Are Lone Mothers Responsive to Policy Changes? Evidence from a Workfare Reform in a Generous Welfare State. The Scandinavian Journal of Economy, 114, 1129-1159.

NOU 2011: 7. (2011). Velferd og migrasjon - den norske modellens framtid. Oslo: Barne-, likestillings- og inkluderingsdepartementet.

Revold, M. K., Sandvik, L., \& With, M.L. (2018). Bolig og boforhold - for befolkningen og utsatte grupper (Statistisk Sentralbyrå (SSB) Rapport 13/18). Hentet fra https:// www.ssb.no/bygg-bolig-og-eiendom/artikler-og-publikasjoner/bolig-ogboforhold

Skevik, A. (2001). Family ideology and social policy: policies towards lone parents in Norway and the UK (NOVA Rapport 7/o1). Hentet fra http://www.hioa.no/ Om-OsloMet/Senter-for-velferds-og-arbeidslivsforskning/NOVA/Publikasjonar/ Rapporter/2001/Family-Ideology-and-Social-Policy

Solberg, S.M. (2013). Slik svindler unge jenter Norge. Nettavisen. Hentet fra: https:// www.nettavisen.no/\%C3\%B8konomi/slik-svindler-unge-jenter-norge/3593205.html

Solvang, F. \& Tunheim, H. (2011, 9. mars). 100 somaliske kvinner fikk barn med eksmannen. NRK.no. Hentet fra https://www.nrk.no/norge/10o-fikk-barn-medeksmannen-1.7541771

Stortinget (2011). Interpellasjon, møte 12. april 2011. Hentet fra https://www. stortinget.no/no/saker-og-publikasjoner/Publikasjoner/Referater/Stortinget

Stortinget (2015). Sak nr. 16, møte 11. juni 2015. Hentet fra https://www.stortinget.no/ no/saker-og-publikasjoner/Publikasjoner/Referater/Stortinget

Strandhagen, S. (1989, 8 august). Jeg anklager: Latsabber, unnalurere, giddalause, uhøflige, respektløse, kravstore, uansvarlige og lettsindige kvinner. Dagbladet, del 1, s. 8 . 
Syltevik, L.J. (1996). Fra relasjonelt til individualisert alenemoderskap: En studie av alenemødre som mødre, lønnsarbeidere og klienter $i$ velferdsstaten (Doktoravhandling). Sosiologisk institutt, Universitetet i Bergen.

Syltevik, L.J. (1999). Endret velferdspolitikk for alenemødre - Fra relasjonelt til individualisert alenemoderskap. Tidsskrift for velferdsforskning, 2(2), 85-101.

Syltevik, L.J. (2015). 'Enslig mor' - forståelse av «problemet» og trygd gjennom 100 år. Tidsskrift for velferdsforskning, 18(4), 328-338.

Terum, L.I. (1993). Stønad, samliv og sjølvforsørging. Om korleis eineforsørgarane brukar overgangsstønaden frå folketrygda (INAS Rapport 1/93). Oslo: Institutt for anvendt sosialvitenskapelig forskning.

TV2 (2011). Somaliske kvinner på trygdetoppen. TV2. Hentet fra https://www.tv2. no/a/3385659/

Tønseth, H. (2014). Flere alenemødre avhengige av sosialhjelp. Samfunnsspeilet, 27(1), 23-29.

VG-debatt (2007). Trygdesvindel hos norsk-somaliske kvinner. VG. Hentet fra https://vgd.no/index.php/samfunn/innvandring-rasisme-og-flerkultur/ tema/1245037/innlegg/

Wang-Naveen, M. (2008, 7. februar). Hva er galt med somaliere? Aftenposten. Hentet fra: https://www.aftenposten.no/meninger/debatt/i/O 3 Ozw/Hva-er-galt-medsomaliere

Wærness, K. (1972). Verdikonflikter ved realisering av sosiale hjelpetiltak for enslige mødre (Hovedoppgave). Sosiologisk institutt, Universitetet i Bergen.

Zucchino, D. (1997). Myth of the Welfare Queen. New York: Simon \& Schister. 


\title{
ARTIKKEL 6
}

\section{Myten om fengselspinen ${ }^{1}$}

\author{
Ingrid Rindal Lundeberg, forsker, Norce/seniorrådgiver i \\ Rusreformutvalget
}

\section{Abstract}

Title: The Myth of "Prison Pain". Summary: The pain of punishment and imprisonment has been widely discussed in prison research. In line with established penal/criminal theory and politics, imposing punishment within the institution of law means inflicting pain. The sociology of imprisonment literature has traditionally focused rather narrowly on the pains of imprisonment; on the "weight, depth and tightness" experienced by prisoners. Empirically-grounded comparative analysis of prisoners' own views on important contributing factors to strengthening their quality of life in prison and their decision to abstain from future crime and drugs is scarce. In the 21st century, Norwegian criminal justice policy has shifted towards an increasing emphasis on human rights discourses and rehabilitation policies. The "principle of normalization" is a humanist hallmark of the Norwegian prison systems, implying prisoners' equal access to the welfare rights shared by all Norwegian citizens. During the incarceration period, prisoners' rights to satisfactory accommodation, education or training, employment, health and social services, and financial advice, seek to create the best possible conditions for an offender's re-integration into society after release. Despite such constructive changes within correctional services, the question remains how such changes have altered the prison experience and softened the pains of imprisonment. Based on comprehensive qualitative and quantitative data on life before, during and after imprisonment, this article presents a more nuanced picture of the varying Norwegian correctional institution standards. With the help of ex-criminals' and inmates' present and past experiences, the article contributes to an understanding of how the different prison-condition qualities that prisoners are exposed to can contribute to constructive change. By addressing the prisoners' own reflections on their feelings, pain, pleasures, gains and losses regarding today's penal practice, the article wishes to contribute to a constructive debate on what current and former prisoners value as supportive and fair, and what they perceive to be offensive and unfair. We cannot, the article argues, assume that punishment is always, and in each case, perceived as pain without further investigation of how punishment is actually experienced and how it varies. The comparative approach - how prisoners perceive and experience the varying conditions they are subjected to in prison, and how they deal with it - must be a core concern in the study of captive society. Accordingly, theories of punishment and painfulness must reflect the recent years' changes evident within both penal practice and policies.

Keywords: punishment, imprisonment, empowerment, rehabilitation, pains of imprisonment

Sitering av denne artikkelen: Lundeberg, I.R. (2018). Myten om fengselspinen. I K. Christensen \& L.J. Syltevik (Red.), Myter om velferd og velferdsstaten (s. 123-145). Oslo: Cappelen Damm Akademisk. https://doi.org/10.23865/noasp.47.ch6

Lisens: CC BY-NC 4.0 
Et hovedstengsel mot innsikt i egne samfunnsforhold er arrangementenes selvfølgelighet. For å kunne se våre samfunn, må vi skape avstand, stå utenfor. Ord, litt annerledes enn de vanligvis anvendte, er midler til å skape avstand. Nye ord, litt på kanten, kan være nyttige, så lenge de er nye. Men etter en tid må de legges i lageret for sløv redskap. (Christie, 1987, s. 283)

\section{Straffens pine og fengslets smerter}

Utgangspunktet for denne artikkelen er å trekke frem noen fangers erfaringer med norske soningsforhold som nyanserer myten om straff som en pine. Straffens pine eller smerte har vært en etablert forestilling i fengselsforskningen. I tråd med straffeteori er fengselsstraffen en tilsiktet pine som skal virke avskrekkende. Formålet med denne artikkelen er ikke å underkjenne eller tilsløre de ofte sterkt pinefulle aspektene ved straff, men å problematisere at «pineteoriene» tar for gitt at straff alltid og i hvert tilfelle oppleves som en pine, uten nærmere undersøkelser av hvordan straff faktisk praktiseres, oppleves og kan variere. Mytestatusen til straff som noe som utelukkende er grunnleggende smertefullt, gjenspeiler seg i at andre forståelser, oppfatninger og opplevelser av ulike former for straff $i$ liten grad blir anerkjent, inkludert eller diskutert.

Bakgrunnen for diskusjonen om straffens pine eller smerte har flere opphav. I norsk sammenheng knyttes pinetenkningen kanskje først og fremst til en sentral diskusjon som strafferettsteoretikeren Johs. Andenæs startet allerede i 1962. Andenæs definerte straff som «... et onde som staten tilføyer en lovovertreder på grunn av lovovertredelsen, i den hensikt at han skal føle det som et onde» (Andenæs, 1976, s. 352). Denne definisjonen står fortsatt sentralt og er senere blitt sitert og gitt tilslutning av Høyesterett ([Rt.] 1977 s. 1207). Samtidig har det vært en pågående debatt i kjølvannet av Andenæs' kjente formulering, som handler om i hvilken grad hensikten med straff er å påføre noen et «onde» eller en «pine». Kriminologen Nils Christie (1982) og idéhistorikeren Espen Schaanning (2002) har kanskje vært av de mest profilerte i den etterfølgende pinediskusjonen. ${ }^{2}$ Begge har argumentert for det syn at siden straffens kjerne er en tilsiktet pine, må den også beskrives som $\operatorname{det}^{3}$ (Fredwall, 2017, s. 24). Deres sentrale poeng er at når straff omtales og beskrives av lovgiver, dommere og andre 
ansatte i straffesakskjeden, brukes ord og uttrykk som skjuler hvordan straffen føles og erfares hos dem som er mottakerne. Det er dermed et problem at pinebegrepet ikke finnes i kriminalomsorgens språk, fordi det ikke dekker over, men viser «... hvordan straffene svir, hvordan de føles, lidelsen, skammen og sorgen» (Christie, 1982, s. 19). Om hensikten med straffen faktisk er ondepåføring, og om dette begrepet dermed bør være en sentral del av selve definisjonen av straff, har siden vært omdiskutert (Fredwall, 2017; Kinander, 2013).

Mens den overnevnte diskusjonen primært er fokusert om formålet med straff, hvordan straffen begrunnes, har den klassiske fengselssosiologiske forskningen vært mer opptatt av å gjøre empiriske undersøkelser av opplevelsen av straff. Straffebegrunnelser sier ikke nødvendigvis noe om hva som skjer innenfor murene, om innholdet i soningen. Kvalitativt orienterte studier i sosiologiens gullalder, ikke minst etnografiske arbeider, har bidratt til at fengselsinstitusjonenes indre liv har blitt synliggjort og fangenes perspektiv og erfaring har kommet frem (se f.eks. Clemmer, 1940; Goffman, 1967; Mathiesen, 1965; Sykes, 1958). Denne forskningen har imidlertid også i stor grad vært smertefokusert. En rekke studier har dokumentert fengselssmertene og hvordan fangekulturer oppstår som et forsvar mot lidelsene, påkjenningene og fornedrelsen som frihetstap innebærer. Gresham Sykes' (1958) begrep om «the pains of imprisonment» har i denne sammenheng vært et svært viktig bidrag. Gjennom sin undersøkelse av et maksimumssikkerhetsfengsel i USA viste han hvordan fangenes sosiale verden måtte forstås som et forsøk på å takle og overleve de lidelsene fengslet utsatte dem for. Sykes (1958) identifiserte spesielt fem former for «fengselssmerter» («pains of imprisonment»). Den første er tap av frihet, det vil si samfunnets intenderte smerte. Videre mister fangene retten til eierskap og dermed kontroll over egne omgivelser, de fratas muligheten til heteroseksuelle relasjoner (kun fă unntak, f.eks. ved besøk), og de frarøves autonomi (selvstyring) over hverdagslivets små handlinger (f.eks. måltider og toalettbesøk). Endelig beskriver Sykes fangenes opplevelser av manglende fysisk sikkerhet i fengslet: «the constant companionship of thieves, rapists, murderers [...] is far from assuring» (1958, s. 77).

Både internasjonal og norsk forskning har senere underbygget og videreutviklet dette pineperspektivet på straff. De etterfølgende forskerne har 
på omfattende måter fastslått at fengslet primært fungerer som en kriminalitetsskapende institusjon, som for de fleste først og fremst bare bidrar til ytterligere marginalisering (Crewe, 2009; Christie, 2000; Hauge, 2001; Mathiesen, 1965; Mjåland, 2015). Flere bidrag har vist til at pinene ved fengselsopplevelsen også må forståes i lys av at fangebefolkningen er en særlig marginalisert og sårbar gruppe (Friestad \& Hansen 2004; Revold, 2015; Skardhamar, 2003; Nilsson 2002). Den typiske fangen er en mann som i forhold til befolkningen for øvrig oftere er skoletaper, har dårligere sosialt nettverk og vanskeligere familieforhold, er oftere fysisk og psykisk syk, bruker oftere narkotika og har dårligere tilknytning til arbeidsmarkedet. Fengselsoppholdet bidrar til ytterligere marginalisering ved at innsatte gjennomgår en "prisoniseringsprosess», der de tilegner seg holdninger og kunnskap om lovbrudd. De kriminelle ferdighetene blir dyrket og perfeksjonert slik at de blir løslatt som mer kriminell enn de var da de ble satt inn, noe som bidrar til at sjansen for tilbakefall øker (Hauge, 2001). Dette underbygges av den «totale institusjonens» krenkelsesprosesser (Goffman, 1967). Innsatte gjennomgår en prosess der de mister evnen til å leve et selvstendig liv. Den innsatte blir fratatt alle materielle og sosiale støttepunkter for den identiteten han/hun hadde i sitt tidligere liv. Pinene som innsatte erfarer under fengselsoppholdet, handler ikke bare om innesperring, frihetsberøvelse og tvangsbruk; dette handler også om den sosialpsykologiske krenkelsen knyttet til distribusjon av stigma, den undertrykkelsen som ligger i å bli definert som mindreverdig ved å bli stemplet som kriminell. I fengsel og i forlengelsen av et fengselsopphold kan en degraderende moralsk karriere utvikle seg. De innsatte opplever ofte at fengselsoppholdet forsterker et stigma ved at statusen som umoralsk, viljesvak, udisiplinert, fange og kriminell blir en masterstatus som overgår alle andre og langt viktigere personlige kjennetegn. Samlet viser den smertefokuserte fengselsforskningen som er gjennomgått ovenfor, hvordan fengselsopphold kan skape en nedadgående sosial karriere og kriminalitet. Denne pineforskningen har fortsatt stor betydning.

Selv om det å «fengsles» alltid er forbundet med opplevelser av forskjellige former for «fengselssmerter» (Sykes, 1958), har fengslene gjennomgått betydelige endringer de siste tiårene. Ifølge den offisielle norske 
straffeideologien er fengslets intenderte funksjon utelukkende frihetsberøvelse (Justis- og politidepartementet, 2008). Ellers skal fangene leve et «normalt» liv, så langt det er mulig. Ulike former for rehabilitering, kartlegging og reformarbeid påvirker maktforhold i fengsel i større grad. Omfanget av tiltak, og fremveksten av nye tiltak som skal ha en rehabiliterende effekt, har økt den senere tid. Straffegjennomføringsloven av 2002 (Justis- og beredskapsdepartementet, 2002) og stortingsmeldingen av 2008 (Justis- og politidepartementet, 2008) vektlegger kriminalomsorgens ansvar for rehabilitering. Normalitetsprinsippet er en av pilarene i den norske kriminalomsorgen, og det innebærer at domfelte har de samme rettigheter som andre borgere, og at tilværelsen under straffegjennomføring, så langt det er mulig og sikkerhetsmessig forsvarlig, skal være lik tilværelsen ellers i samfunnet. ${ }^{4}$ Gjennom soningsforløpet skal innsattes rettigheter til en tilfredsstillende bolig, utdanning eller opplæring, arbeids-, helse- og sosialtjenester og økonomisk rådgivning gi best mulige forutsetninger for å integrere lovbryteren i samfunnet etter løslatelse. ${ }^{5}$ Fangene er nå plassert i et bredt anlagt velferdsstatlig apparat som skal endre mennesker til det bedre. Spørsmålet er hva denne rehabiliteringstenkningen innebærer i praksis, og om og hvordan dette faktisk letter fangenes totale opplevelse av pine.

Selv om tilbakeføring er et viktig mål i straffegjennomføring, har det i liten grad vært diskutert hvordan dette kan bidra til en endringsprosess som gjør straff mindre pinefullt. Studier av hva som kan gi innsatte et bedre liv etter løslatelse, og hvordan dette kan variere mellom ulike soningsanstalter, har i liten grad vært trukket frem i diskusjonen om straff. Det er samtidig et problem at «pineteoriene» tar for gitt at straff alltid og i hvert tilfelle oppleves som en pine, uten nærmere undersøkelser av hvordan straff faktisk praktiseres og oppleves. Dette handler også om at straffediskusjonen må gjenspeile de endringer som kriminalomsorgen har undergått siden pinedebatten oppsto. Fangeperspektivet og fangenes opplevelse av soning og forskjeller mellom ulike fengsler innad i land, må ikke bli oversett. Som vi skal diskutere senere, rommer det å sone et vidt spekter av erfaringer, og det er store forskjeller mellom norske fengsler og fanger i deres beskrivelse av hvordan straff føles og virker. 


\section{Metode}

Bakgrunnen for artikkelens analyser er et omfattende, nasjonalt datamateriale om innsattes liv før, under og etter gjennomføring av straff $i$ den norske kriminalomsorgen, med fokus på rehabiliterings- og løslatelsesarbeidet (se også Lundeberg 2017 for en nærmere beskrivelse). Vi har gjennomført etnografisk feltarbeid i fengsel i til sammen ett år, gjort intervjuer med både innsatte, løslatte og ansatte i kriminalomsorgen $(\mathrm{N}=81)$ og foretatt en spørreundersøkelse som ble gjennomført blant fanger i ti norske fengsler $(\mathrm{N}=606)$ med både høyere og lavere sikkerhetsnivå. ${ }^{6}$ Både i intervjuene og spørreskjemaet ble de innsatte bedt om å svare på spørsmål både om tiden før, under og etter soningen. Spesiell oppmerksomhet ble gitt til temaene rus og rehabilitering. Disse undersøkelsene, og datagrunnlaget de resulterte i, er nærmere beskrevet i tidligere publikasjoner (Lundeberg, 2017; Lundeberg \& Mjåland, 2016, 2018; Lundeberg, Ryen \& Mjåland, 2018; Mjåland \& Lundeberg, 2014; Mjåland, 2014, 2015a, 2015b, 2016).

Denne artikkelen har imidlertid ikke som hensikt å presentere bredden i dette datamaterialet, men å trekke frem noen overordnede funn og eksempler som viser konstruktive erfaringer med soning og dermed bidrar til å nyanserer perspektivene på straff som bare smerte. Først skal vi diskutere fangers erfaringer av soningsforhold i ulike fengselskontekster gitt ulike strafferammer, varierende frihetsgrader og progresjonsmuligheter. Deretter skal vi se nærmere på hvilke forhold som gjør at smerten med fengsel lindres, og som fanger trekker frem som konstruktive, hva som gjør at enkelte fanger nyttiggjør seg straff, og hvordan fengselserfaringen kan bidra til en konstruktiv endring.

\section{Straffens åpenhet og kontroll}

Å bli fratatt friheten, opplevelsen av at det er andre som har kontroll over tiden din, at det er myndighetene som har beslaglagt den og bestemmer over den, kan være av det mest pinefulle ved å sone. Hvilken frihet fangene sier de har, og hvordan de forvalter den friheten som finnes, kan imidlertid være sterkt varierende. Dette underbygges av at et særlig fremtredende tema blant fangene er store forskjeller i vurderingen av 
soningsforhold mellom ulike fengsler og fanger. «Det finnes ingen norsk standard», som en fange vi intervjuet uttrykte, er et gjennomgangstema i fangenes omtale av soningsopplevelsene. Fanger med omfattende erfaring med soning forteller om et vidt soningsspekter, der den følelsesmessige belastningen beveger seg i et kontinuum mellom ytterpunkter. Det er særlig kontrasten mellom frihetsgradene og kontrollnivåene på åpne og lukkede fengsler som trekkes frem som betydningsfull av fangene. Den omfattende og utstrakte bruken av varetektsfengsling og isolasjon på enkelte lukkede soningsanstalter (Barker, 2013; Smith, 2011) ble omtalt med en sterk indignasjon blant de berørte. Stor grad av isolasjon setter fangene i en ekstrem situasjon. Presset på følelses- og inntrykksregulering på noen lukkede avdelinger ble rapportert som uutholdelig og førte til ustabilitet og utrygghet. Morten, som hadde lang soningserfaring, fortalte om hvordan dette kunne resultere i et soningsmiljø med et tillitsskjørt fellesskap preget av et uholdbart høyt aggresjonsnivå:

Du kan jo bare se på egentlig samtlige fengsler, liksom hvor ... og så kan du se på åpne avdelinger. Og så kan du se litt på ... hvordan stressmønsteret er til folk. Med ... også med for eksempel slagsmål og så videre. På åpen avdeling så finner du nesten ikke sånne utbrudd, aggresjonsmessig. Mens med én gang du kommer inn på lukkede avdelinger, så jo mer lukkede de er, jo mer aggressive blir de. Du kan jo se nedpå Bjerget f.eks. Der nede ... der har du ... hvor ... hvor du sitter inne på en celle 23 timer i døgnet. Og så får du én time luft. Der nede har du noen tikkende bomber, der. (Morten, 28)

Fangenes tilpasningsstrategier og soningsopplevelser varierer mellom ulike fengselstyper gitt ulike strafferammer, varierende frihetsgrad og progresjonsmuligheter. De innsatte som soner i høysikkerhetsfengsler fokuserer generelt i større grad på smertene ved frihetsberøvelsen og dens konsekvenser, mer eller mindre uavhengig av de varierende fysiske forholdene de er underlagt.

Imidlertid har mange fanger som soner ved åpne fengsler, andre opplevelser av soning. I åpne fengsler sier fangene at det 'moralske klimaet' er langt bedre enn i større, lukkede fengsler. Små og åpne fengsler med stort friområde, høy frihetsgrad og lavt kontrollnivå blir av fanger generelt vurdert som bedre enn høysikkerhetsfengsler (Lundeberg, Mjåland 
\& Rye, 2018). Skillet mellom «harde» (høysikkerhetsfengsel) soninger og «lette» (åpne fengsler) var hyppig omtalt. Jens, som hadde tilbrakt et år under åpne forhold, konkluderte uoppfordret med at han var overrasket over at han på mange måter faktisk hadde trivdes i fengsel, men at det var fordi han hadde sluppet «billig unna»:

Det er nesten sånn at du at du ikke har kunnet sagt til folk at du har vært på soning når du har, altså du har jo hatt en straff, men jeg føler faktisk at jeg hadde hatt litt godt av det og. For å si det på den måten. Og synd og si at man skal trives i fengsel, men så jeg har sluppet unna de harde soningene ... (Jens, 25)

De forskjellene i opplevelsen av tyngden av straff som innsatte forteller om, viser imidlertid ikke bare til erfaringen med å være underlagt ulike sikkerhetsnivåer og innlåsing, slik som i tilfelle med Jens. Noen steder sier fangene at de rett og slett til dels har vært svært fornøyde med den oppfølgingen de har fått, og gir uttrykk for at soningstiden har gjort dem bedre rustet til et liv etter løslatelse, mens andre er misfornøyde.

Noen fengsler ble trukket frem som ganske vellykkede. Aller mest tilfreds med livet i fengsel er fanger i det åpne fengslet Leira i Trondheim. $74 \%$ av fangene som soner der, er enige i at tilbudene som de har mottatt i fengslet, i stor grad har gjort dem «bedre rustet til å møte hverdagen når du slipper ut». Dette er en langt større andel enn i landets øvrige fengsler, der gjennomsnittlig $22 \%$ mener det samme.

Fravær av murer, liten grad av innelåsing, kontroll og regulering av hverdagslivet og en fangebehandling med vekt på rehabilitering heller enn kontroll preger de innsattes hverdag. Dette har også sammenheng med at lukkede og åpne fengsler gir ulike betingelser for å bygge tillitsrelasjoner. Ved fengsler der fangene var mest fornøyde i spørreundersøkelsen vi gjennomførte, var asymmetrien i relasjonen mellom betjenter og fanger forsøkt nedtonet ved bruk av hverdagsklær, en uformell omgangstone og hyppige sosiale aktiviteter der fanger og ansatte trådte ut av tradisjonelle roller (Lundeberg, Mjåland \& Rye, 2018).

Disse eksepsjonelle forholdene gir seg også uttrykk i et rikt fritidstilbud der fangene nærmest opplever en hyperaktiv tilværelse, som for noen overgikk livet de hadde hatt ute i det fri. Dette sier Sveinung, som sonet på en åpen avdeling: 
Har aldri gått på fjellet så mye som når jeg har sittet her. Ja ... det er nesten stygt å si det med under soningen her så har jeg ... jeg har fått gjort ting som jeg aldri ville fått gjort ellers. Jeg går jo mye på fjellet hjemme da, men ikke så mye som jeg har fått gjort her. Og så har jeg vært på håndballkamper, og andre helgen vi var ute her i fjor, da var vi i Bymarka og kjørte på ski. Og det var jo så mye snø i fjor. Vi var jo på Vassfjellet mange, mange ganger og kjørte på ski. RBK-kamp. Jeg hadde aldri før vært på RBK-kamp. Så er det jo ... var i Bymarka nå i helgen. Altså vidden over. Storheia. Gråkaillen. Jeg har vært på Feie. Nordsjøløypa. Sykkelturer. (Sveinung, 52)

Åpne institusjoner med større frihetsgrader tilrettelegger for en mer allsidig identitetsskapende tilværelse med minst mulig «fangeaktig» preg.

Selv om dette nok ikke er hverdagen for mange fanger, utgjør det et eksempel på at det finnes et vidt spekter av soningsforhold i Norge. Utflukter til fotballkamper, slalåm, fjellturer og teaterforestillinger var aktiviteter mange ellers ikke hadde hatt råd til. Mange fangers marginale levekår og en fortid med rus og kriminalitet gjør erfaringsgrunnlaget med konvensjonelle arenaer mangelfulle. Muligheten til å kunne dra ut av fengslet og omgås folk i det frie samfunnet var et særlig verdsatt privilegium i en ellers avskåret og innelukket tilværelse.

En sentral del av fengslets smerteproduksjon er passivisering ved langvarig soning og mangel på kontakt med omverdenen, noe som kan skape ensomhet og sosial angst. Det er alminneligheten ved noen av de erfaringene som fengslet kan tilby, som er noe ekstraordinært for mange av fangene. Å få frihet til å bli eksponert for alminnelige erfaringer og samvær er ikke bare et viktig aspekt ved myndig- og verdiggjøring, men også for å motvirke faren for at innsatte blir institusjonalisert på en sånn måte at de utvikler kompetanse og posisjoner som forsterker deres utenforskap. Åpenheten til omverdenen i aktivitetsfremmende og brobyggende omgivelser kan dermed motvirke pinen ved stigma og at en slik degraderende moralsk karriere i forbindelse med fengselsopphold kan utvikle seg.

\section{Straffens uklarhet og styrke}

Innsattes fortellinger viser ikke bare at institusjonelle forhold som fengslenes ulike kontrollnivå og størrelse har betydning. Domfelte har svært 
ulike erfaringer med straffegjennomføringsprosessen, men de har samtidig det til felles at måten de ble behandlet på, har stor betydning for forvaltningen av det pinefulle ved soning. Hvordan fangene opplever den hverdagslige samhandlingen med og relasjonen til ansatte, påpekes som særlig avgjørende. Maktforhold mellom fanger og betjenter regulerer mye av det som skjer i et fengsel. Fangers underordning blir regulert og understreket av materielle tiltak, fysiske barrierer og kontroll som gitter, celler, nøkler, innelåsing, kameraer, kroppsvisitasjon, urinprøver, celleransakelser og telling. Relasjonen til betjentene er ikke bare viktig i utøvelsen av kontroll og sikkerhetsoppgaver, men også i det løpende endrings- og påvirkningsarbeidet som fangene skal underlegges i størst mulig grad. Betjentene skal ivareta sikkerhet, forebygge konflikter, motivere fanger til å endre seg, gjennomføre terapeutiske samtaler, foreta cellesjekker, urinprøver og kroppsvisitasjoner, være et bindeledd mellom fangen og det øvrige velferdsapparatet, og oppnå en tillitsfull relasjon med fangene (Justis- og politidepartementet, 2000). Samtidig er det store forskjeller mellom fengsler i hvor fornøyd fangene er med oppfølgingen de har fătt fra betjentene, og opplevelsen av tillit og fortrolighet (Lundeberg, Mjåland \& Rye, 2018). Dette ble forsterket av at det også var betydelige ulikheter i måten den enkelte betjenten utøvde sitt skjønn på, og hvordan de ivaretok sine rehabiliterende oppgaver. En kilde til frustrasjon var at fangene var avhengig av å ha en god relasjon til betjentene for å få tilgang til soningsprivilegier og tjenester, på samme tid som selve betjentrollen framstod som uklar. Betjentene fungerte samtidig som portvakter (for tjenester og goder), voktere (som gjennomførte urinprøver, kroppsvisitasjoner, og cellesjekk) og terapeuter. Ulike fengselspolitiske formål og prosjekter - som både er kontrollerende, straffende og rehabiliterende - er virksomme i den konkrete fengselshverdagen, og flettes sammen. Betjentenes veiledende hånd kan i neste øyeblikk bli et fast, tvingende grep, for å bruke den engelske fengselsforskeren Ben Crewes metafor (2009). Usikkerheten om når den veiledende hånden som strekkes ut, kan bli til et hardt grep, gjør at ethvert håndtrykk ofte møtes med en viss skepsis. Den blandingen av myk og hard makt som dette bilde illustrerer, er et omdiskutert tema i den nåtidige fengselsforskningen (se f.eks. Bosworth, 1999; Crewe, 2009; Hannah-Moffat, 2000; Mjåland, 2015; Mjåland \& Lundeberg, 2014; 
Shammas, 2017). De nye «soningssmertene» som denne forskningen beskriver, handler ikke nødvendigvis bare om et mer utflytende skille mellom tiltak som er «harde» og «milde», men også om opplevelsen av det inkonsistente og uberegnelige i de stadig skiftende reaksjonsformene. Særlig på avdelinger med rehabiliterende formål preges relasjonene fort av ambivalens uklare roller og regler. Fengslets smerteproduksjon blir sterkere knyttet til rolleuklarheten mellom fange og betjent (Mjåland \& Lundeberg, 2014; Lundeberg \& Mjåland, 2018).

Opplevelsen av pine handlet også om hvorvidt den hverdagslige omgangen mellom ansatte og fanger opplevdes som respektfull. Innsatte opplever at dette forvaltes på mer eller mindre krenkende, hensiktsmessige eller respektfulle måter. Tilfeller av behandling som bidro til en følelse av mindreverd og avmakt, omfatter en vid rekke av hendelser, alt fra krenkende omtaler til «mikroydmykelser» i dagligdagse situasjoner som skuldertrekning, avstandtaking og taushet. Fengslet er en særegen samhandlingsarena ved at ethvert samvær kan være redskap til å vurdere farlighet, motivasjon og endringsvilje. Et særlig mistillitsskapende forhold knyttet til mangelen på medvirkning og kommunikasjon er de tilfeller der inngripende beslutninger er basert på dagligdagse samvær og observasjoner, uten at fanger nødvendigvis har vært klar over at de har blitt vurdert, eller hva ansatte legger vekt på i ulike situasjoner og rapporterer videre.

Forskningen vår viser samtidig at de som var fornøyde med oppfølgingen i fengslet, hadde opplevd individuell tilrettelegging og brukermedvirkning. Andre studier har også vist at brukere som aktivt medvirker i behandlings- og rehabiliteringsprosessen og får eierskap til egen endring, har bedre resultater (DiClemente, 2003; Helgesen, 2017; Lundeberg 2017; Lundeberg \& Mjåland, 2016; Maruna, 2001). Brukermedvirkning er ikke bare viktig for å sikre et tilstrekkelig beslutningsgrunnlag og en god skjønnsbruk, men kan også ha en skadereduserende funksjon ved å hindre unødig kontroll og krenkelser (Lundeberg et al., 2010). Et viktig aspekt av brukermedvirkningstenkningen som legger føringer for fangebehandlingen i «det senmoderne fengslet», er å gi fanger mulighet til og ansvar for å være drivkraften i egen endringsprosess, og at de får være med på å utforme soningsmiljøet (Kriminalomsorgsdirektoratet 2016; 
Helsedirektoratet 2016). Brukermedvirkning er et prosessuelt ideal i velferdsstatens hjelpeapparat, og kan i en fengselskontekst forstås som metoder som bygger på fangers initiativ, delaktighet og innflytelse (Askheim, 2010).

Dette illustreres godt gjennom erfaringene til Alex. Vi intervjuet han etter at han ble løslatt fra soningen av en flere år lang dom for sedelighetslovbrudd. På bakgrunn av det han hadde gjort, opplevde han at det daglige samværet med de ansatte ble gjennomført med et overdrevent sikkerhetsfokus. Behandlingen ble preget av avstand, manglende respons og nedlatende bemerkninger; mikroydmykelser som virket stigmatiserende. Etter hvert blir han overført til et av de større fengslene i Norge som har en egen avdeling og program for sedelighetsdømte. Slik beskriver Alex hvordan han opplevde det første møtet med dette fengslet:

Så jeg ble flyttet opp der på prøve i tre dager. Skulle se om jeg likte meg der og jeg smeltet jo rett inn, dette er ... var kanon, de tok meg inn med et ... armer ... eller de tok ... de tok så godt imot meg, da. De tok liksom i varmen og det er jo faen ingen som har tatt tatt imot meg i varmen, liksom. Det er ingen ... ingen før. Jeg har jo sittet på det jævla rommet mitt og kvidd meg til å gå ut. Plutselig så kommer du inn til den varmen og de følelsene ... (Alex, 21)

Han beskriver hvordan de ansatte på en behandlingsavdeling tok imot han med en genuin varme og åpenhet som han aldri tidligere hadde opplevd:

Plutselig så kommer du inn til den varmen og de følelsene ... og de spør deg; hva skal du gjøre og hva skal du gjøre under soningen din, og hva vil du bruke tiden din til og ...? For jeg ville begynne med meg selv, da. Jobbe med meg selv.

Alex opplevde at han hans hjelpebehov var i fokus, og at han ikke ble vurdert som et farlig risikomoment. Avdelingen ble drevet av en blanding av sosialarbeidere, psykologer og betjenter. Psykologen som han gikk i terapi hos, var ikke opptatt av hva han hadde gjort, men hvem han var. Hun spurte han først et stykke ut i soningen om det var i orden at hun leste dommen hans. Alex opplevde at han fikk ta styringen over sin egen soningsplan. Å bli behandlet som en unik person med et vidt spekter av 
ressurser, evner og muligheter, og ikke som en notorisk farlig og risikabel kriminell bidro til at han bestemte seg for å «utlevere seg selv» og starte på en langvarig prosess med sikte på å etablere et nytt og bedre liv etter løslatelsen (Lundeberg \& Mjåland, 2016).

Diskusjonen ovenfor viser at på tross av at domfelte har svært ulike erfaringer med straffegjennomføringsprosessen, vektlegger samtlige av fangene i vår undersøkelse at måten de ble møtt, sett, hørt og behandlet på gjennom soningsløpet, har avgjørende betydning for forvaltningen av det pinefulle ved soning. Et viktig spørsmål i diskusjonen om fengslets smerteproduksjonen fremover er samtidig hvordan den dagligdagse samhandlingen og relasjonen mellom fanger og ansatte i mindre grad oppleves som direkte autoritær og «hard», og mer som et uklart maktforhold som fremstår som mykere og tettere.

\section{Straffens ansvarliggjøring}

Spørsmålet om fengslets mulige piner handler ikke bare om hvordan betjentene utfører sin rolle, og hvordan fengslet bidrar til endringspress og -lyst hos fangene, men også om tyngden og vekten av å ta eller bli overlatt ansvaret for å ta styringen over egen selvutvikling gjennom soningsløpet. Ansvarliggjøring er et sentralt styringsverktøy i de nye og senmoderne formene for straffideologi og -praksis (Bosworth, 2007; Garland, 2001; Hannah-Moffat 200o). Dette viser seg i at krav til fangenes ansvar for egen progresjon er et særlig fremtredende trekk i kriminalomsorgens styringsstrategier (Justis- og politidepartementet, 2008). Fanger som tidligere var objekter for straffen, skal nå gjøres til subjekter som er kompetente til å styre seg selv. En slik ansvarliggjøringstenkning var også et fremtredende tema blant fangene. Kravet om å bearbeide og jobbe med seg selv igjennom soningsløpet gjorde for noen straffedømte soningen lettere, for andre heller tyngre og tettere.

Betydningen av å bli ansvarliggjort i sin egen endringsprosess var et særlig viktig tema blant de «vellykkede» eks-kriminelle som vi intervjuet. Uavhengig av hvor de hadde sonet, og hvilken oppfølging de fikk, betraktet de fengselserfaringen først og fremst som en del av en avgjørende endringsprosess der de selv tok styringen. Hvilke endringsprosesser 
de har gjennomgått, er varierende, men selve fengslingen fremstilles ofte som en kritisk hendelse eller «oppvåkning». Dette var tilfellet for Rolf, en av de eks-kriminelle som hadde brukt store deler av livet sitt til å bli en suksessrik storsmugler av narkotika med høyt pengeforbruk og et samtidig eskalerende misbruk. Han forteller hvordan møtet med høysikkerhetsfengslets harde behandling av ham var et konkret sterkt emosjonelt ladet øyeblikk:

Jeg satt i fengsel og følte meg bitteliten og alene, jeg hadde jo mistet alt, sant. Celledøren smeller igjen bak deg og så sitter du på isolat på 23,5 timers innlåsing og isolasjon fra alt, sant - og uoversiktlig fremtid på hvor lenge det blir - Så er dette ganske langt unna livet i det fri da, uten grenser. Så for meg var det der en vekker, etter den dagen der har jeg aldri rust meg igjen. (Rolf, 28)

I hans livshistorieberetning blir fengslingen trukket frem som et smertefullt vendepunkt i hans kriminelle karriere. De fleste eks-kriminelle har ikke en slik sterk opplevelse/erindring av når endringen egentlig inntraff, eller kan trekke frem en helt konkret vendepunkthendelse, slik som Rolf. Imidlertid beskriver personene som lykkes i å slutte med kriminalitet, at fengslingen var starten på det som kan kalles en endret «selvforholdningsmåte», som det videre soningsforløpet tilrettela for i ulik grad. Soningen blir fremstilt som en kritisk selvbearbeidingstid, som en mulighet for en konstruktiv tenkepause som resulterte i at de selv etter hvert tok beslutningen om å ta ansvar i egen endringsprosess. Å ta ansvaret for endring krevde imidlertid en sterk overbevisningskraft om egen styrke. Det er kun opp til en selv, som Anders sier, det handler om å være 100 prosent dedikert:

Anders: Jeg tror det har veldig mye med hvilken innstilling du har før du setter i gang med det. Jeg tror det blir jævlig vanskelig eller jeg tror du vil slite veldig hvis ikke du er helt $100 \%$ sikker eller innstilt på at dette skal ... dette skal du klare. Ja, hvis ikke du er helt ... hvis ikke du er helt klar for det, så tror jeg det kan være veldig vanskelig.

Forsker: Så det er liksom ikke rom for ambivalens eller usikkerhet, på en måte, den prosessen der, tenker du?

Anders: Nei, jeg tror ikke det. Den personen som skal gjøre det, tror jeg rett og slett må må ... må komme til et punkt hvor de føler at nå må jeg enten 
komme meg på riktig side eller så er det løpet kjørt. Og jeg jeg tror ... jeg tror faktisk jeg var kommet litt på det punktet. (Anders, 29)

En sterk enten eller-tenkning, en nærmest fatalistisk holdning, der betydningen av eget initiativ og innsats ble avgjørende, var utbredt. Man rehabiliterer seg selv; fengslet, kriminalomsorgen, velferdsstaten, NAV, terapeut, familie, jobb, alder og tid kan ikke forandre en person som ikke gjør personlige anstrengelser for å forandre seg selv, «fra innsiden».

Typisk for denne prosessen var at det belastende livet som mange levde i tiden før fengslingen, ble gransket med større kritisk distanse:

Og det forandret jo på alt, altså da skjønte jeg virkelig ... jeg bestemte meg at jeg aldri skulle tilbake igjen på den livsstilen der. Jeg hadde jo aldri tenkt over det, nesten, det er rart å si det, men da så jeg ingenting før det. Da gikk det opp for meg hva jeg hadde holdt på med. (Nils, 32)

Et gjennomgående trekk er at de bruker sterke begreper om den forandringen de sier de har gjennomgått. Soningstiden beskrives som en personlig kamp og fremstilles som livsforandrende og et livshistorisk «brudd». Uttrykk som at de har «gjenvunnet kontroll over seg selv», eller beskriver soningen som at det var «en gjenoppbygging av meg selv», er utbredt. Petter forteller om at «det var en oppvåkning i hvordan han hadde levd tidligere»:

Ja, jeg har våknet opp litt for å si det på den måten. Så har jeg fått et helt annet syn på tingene. Det har jeg, innforstått litt mer at hadde jeg vært uten litt tidligere så hadde jeg ikke vært her i dag. For å si det sånn. Så jeg ser jo hva det har gjort med meg tidligere da, så jeg vil si jeg har absolutt fått øynene opp litt ja. (Petter, 33)

Soningen blir samtidig forstått som en del av en indre reformativ prosess med økt bevisstgjøring over negative konsekvenser knyttet til langvarig forhold til rus og kriminalitet.

Så det ... jeg var litt glad for å bli tatt òg, fordi at selv om jeg ikke ruset meg, så tror jeg at det ... hvis ikke jeg hadde blitt tatt, så hadde jeg fortsatt med det, sant. Og ... ja. (Anders, 29) 
«Oppgjøret» de forteller om, innebærer at tidligere kriminelle handlinger blir fordømt, «det gikk opp for meg hva jeg holdt på med», men på en forsonende måte. Avstandstakingen er ofte knyttet til at personen av ulike grunner mener at han ikke var seg selv under den aktuelle handlingstiden, noe som han i mer eller mindre grad selv kan klandres for. De snakker om fortiden som om det var en annen person, «det var ikke egentlig meg». Selvbearbeidingen innebærer å etablere (nye) kjerneoppfatninger om seg selv, gjennom å artikulere hva de mener karakteriserer deres egen «sanne kjerne», det innerste jeg. Ved å fremstå som aktive, handlingsrettede og nærmest hypermoralske i sin omtale av sin endringsprosess blir deres kriminelle fortid og tidligere status som farlig og umoralsk lovbryter bearbeidet.

Selv om denne livshistoriske selvbearbeidingen innebærer et smertefullt oppgjør med fortiden, fremheves det samtidig i forskningen som et avgjørende punkt for en vellykket tilbakeføring (Maruna, 2001). Ved å bearbeide fortiden forsøker personen å skape et sammenhengende fortelling for å forklare og rettferdiggjøre endring. Eks-kriminelle drar nytte av en logisk, troverdig og respektabel historie som demper skyld- og skamfølelse, og som er forenelig med å bevare selvrespekten for å forklare hvorfor de har blitt streite.

Ansvarliggjøringen som vi har diskutert ovenfor, resonnerer samtidig med en mer subtil styringsstrategi av borgere, der formålet med soning er at innsatte skal foreta en kontinuerlig indre etisk og moralsk rekonstruksjon (Rose, 2000). Den innsatte skal bevisstgjøres og forstå seg selv som et handlingsdyktig, fritt og refleksivt individ og sitt liv som resultatet av egne valg. Dette gjør samtidig at de som ikke lykkes med å gjøre seg selv til noe annet enn fange, skylder på seg selv og egen tilkortkommenhet. Fanger som er passive, tiltaksløse og tilbakeholdne og ikke bruker de muligheter som soningstiden gir for endring, opplever en form for mindreverdsfølelse og skam. De klandrer seg selv for sin egen udugelighet og uttrykker skyldfølelse overfor friheter de ikke viser seg fortjent til. Ansvarliggjøring skaper en situasjon der de som faller utenfor, føler de selv har påført seg den pine de får i utenforposisjonen i samfunnet, som om det bare var et resultat av egne dårlige valg. Spørsmålet om ansvarliggjøringens mulige piner er avhengig av om den virker reelt myndiggjørende, og hvordan 
innsatte selv føler de kan ta ansvar for å være drivkraften i egen endringsprosess ut fra de mulighetene som soningsforholdene gir.

\section{Straffens plan og fremdrift}

Selv om mange mente at det de hadde klart å oppnå under og etter fengselsopphold, var noe de hadde «ordnet selv», kom det likevel i mange tilfeller fram at kriminalomsorgen i betydelig grad hadde bidratt til fremdriften og tilretteleggingen for den enkeltes endringsprosess. Oppfølgingen fra kriminalomsorgen kan dermed være avgjørende for videre kriminalitet, ved at denne evnen og/eller viljen til konstruktiv endring styrkes. Mens mange fanger uttrykker at en sentral del av soningens smerter er manglende viten om hva fremtiden bringer, oppgir noen at soningen har gitt håp, plan og retning. Særlig gjelder dette å skaffe seg utdanning, få bolig og å komme i arbeid eller arbeidsrettede tiltak. Innsatte i norske fengsler har aktivitetsplikt (jf. Justis- og beredskapsdepartementet, 2002, \$3). På dagtid skal fangene arbeide, få undervisning eller delta i andre godkjente aktiviteter. Våre undersøkelser viser at det finnes et vidt spekter av tilbakeføringstiltak i noen norske fengsler. Det er imidlertid store variasjoner i aktivitetene som tilbys i ulike fengsler. Arbeidsrettede tiltak er imidlertid det de innsatte selv mener er det mest meningsfylte og viktigste tiltaket for å klare å leve lovlydig (Lundeberg, 2017). Arbeid er av de viktigste faktorene for å beskytte mot tilbakefall, og manglende arbeidserfaring er et problem for fangenes tilbakeføring (Kyvsgaard, 1998; Sampson \& Laub, 2003; Skardhamar \& Telle, 2012). Arbeidets kriminalitetsreduserende effekt har sammenheng med at de som har dårligst arbeidsmarkedstilknytning før soning, blir tilbudt arbeidstrening og -opplæring i fengsel, som de drar nytte av etter soning (Bhuller, Dahl, Løken \& Mogstad, 2016). Soningen gir mulighet for arbeidserfaring og kompetanseheving til en særlig marginalisert befolkningsgruppe som det ellers ville ha vært vanskelig å nå.

Alfs soningshistorie er et godt eksempel på mulighetene i en planmessig, aktiv og individuelt tilrettelagt soningstid med arbeidskvalifisering $i$ fokus. Han hadde tilbrakt store deler av sitt liv under ulike fengselsopphold, men på intervjutidspunktet har han lyktes med å bli rusfri, løslatt og 
er i fast arbeid. Alf hadde i likhet med andre «vellykkede» eks-kriminelle i utvalget vårt over tid utviklet gode relasjoner til en flerfaglig stab i fengslet, som han opplevde som pådrivende støttespillere i møtene med velferds- og hjelpeapparatet ute. Han tok hele den videregående utdannelsen som tømrer under et tidligere fengselsopphold. Under siste soning fikk han fri for å gå på en rekke visninger på leiligheter og på jobbintervjuer, uten følge av betjenter. Videre fikk han støtte og tillatelse til å delta på et jobbsøkerkurs i regi av NAV. Alf syntes det hjalp han til å forstå bedre hvordan han skulle representere seg selv og egen kompetanse overfor potensielle arbeidsgivere. Særlig nyttig var det å få opplæring i å utforme en troverdig CV som samtidig kunne dekke over hans mange fengselsopphold.

Hvordan den enkelte klarer å kvalifisere seg i soningstiden, overbevise potensielle arbeidsgivere om sin kompetanse og reforhandle sin kriminelle fortid i møte med arbeidslivets aldersnormerte forventninger til et yrkesaktivt livsløp, er et kritisk punkt i tilbakeføringsprosessen. Lovbrytere har større tilbøyelighet til å slutte med kriminalitet hvis de lykkes med å etablere sosiale bånd og konvensjonelle roller knyttet til familie og arbeid. De fleste innsatte mente at et annet og mer rus- og kriminalitetsfritt liv krever drastiske endringer og flere roller utenfor. Denne krevende endringen er for de fleste ikke resultatet av en enkeltstående hendelse, men en prosess der en kjede av faktorer virker inn over tid, der tidligere forsøk på oppfølging kan være av stor betydning, selv om personen ikke fullførte de aktuelle tiltakene. Både tidligere forsøk på hjelp som personen ikke benyttet seg av, avbrutte og fullførte hjelpetiltak kan bidra konstruktivt i en endringsprosess. Å ha en plan, og ha tro på den, å ikke gi opp, men holde fast ved en fremtidsoptimisme på tross av brudd og tilbakefall, en tro på at endring faktisk er mulig, som ansatte og innsatte sammen kan bidra til, er i seg selv både viktig for å lykkes og for å lindre smertene ved livet både innenfor og utenfor murene.

\section{Minst mulig pine - å lindre smerte}

I denne artikkelen har jeg forsøkt å nyansere diskusjonen om straff som en tilsiktet pinepåføring ved å vise at straff ikke nødvendigvis oppleves som pine, men kan innebære mulighet for konstruktiv endring. Dette har 
sammenheng med at fengselsforholdene har blitt materielt bedre, at den $ø$ kte satsningen på rehabilitering og velferdstilbud har gitt fangene flere rettigheter og valg, og at fengslet er blitt et mer meningsfullt sted å være og gir fangene flere muligheter, noe som kan gjøre fengselsopplevelsen mykere og lettere. Det finnes fengsler der fangene trives, som oppleves som meningsfulle, og noen oppgir at soningen har gitt et håp, en plan og en retning i livet som de ikke har hatt tidligere. Særlig gjelder dette å skaffe seg utdanning, få bolig og å komme i arbeid eller arbeidsrettede tiltak. Vi har diskutert hvordan fengselspolitikken har endret seg betydelig de siste tiårene. Rehabilitering, kartlegging og reformarbeid påvirker i stor grad maktforhold i fengsel. Selv om fengselsmakten fremdeles er autoritær og «hard», så framtrer den i mange tilfeller som «mykere». De nye pinene ved å være i fengsel knyttes til den sterke behandlings- og rehabiliteringsideologien som preger de nordiske fengslene. Dette gjør ikke nødvendigvis soningsforholdene lettere. Et soningsregime med strenge aktivitetskrav og pålegg om selvdisiplinerende endringsarbeid, der fangene blir satt til å bearbeide og jobbe med seg selv igjennom soningsløpet, kan heller gjøre straffen tyngre og tettere enn lettere.

Samtidig viser innsattes erfaringer at straff er et mangfoldig fenomen som kan være smertefullt, men at opplevelsen av straff varierer. Norske fengsler innebærer et stort mangfold. Ved å vektlegge fangenes perspektiv og deres opplevelse av soning og ulikheter mellom avdelinger og fengselstyper, viser vi at det finnes forhold ved norsk soning som innsatte definerer som konstruktive, som gir noen innsatte mulighet til å etablere et nytt og bedre liv. Pineforståelsen av straffens hensikt skjuler og dekker over disse variasjonene. Et grunnleggende problem med pineforståelsen er at den ikke skiller mellom straffens artikulerte hensikt og den opplevde virkning (Fredwall, 2017). Ved å avgrense straff som pine blir debatten om hva som faktisk skjer i fengslene, preget av forestillinger og verdiladninger som verken er treffsikre eller fører til en konstruktiv debatt.

Artikkelen viser viktigheten av at diskusjonen om straffenivåer, straffens begrunnelser og funksjon må relateres bedre til hvordan straffegjennomføringen faktisk praktiseres og virker. Det er særdeles viktig at debatten om straffenivået i samfunnet ikke bare handler om 
straffeutmålingen og dens formål, men også om hva som skjer i soningstiden, og hvordan straff oppleves i ulike anstalter. Det er viktig for oss som fengselsforskere å ikke bare vektlegge det sterkt pinefulle med straff, men å vise hvordan dette kan variere, og trekke frem de gode eksisterende tiltakene innenfor kriminalomsorgen som gjør straffen både mer hensiktsmessig og meningsfull.

\section{Sluttnoter}

1. Kapittelet ble revidert med mindre endringer i januar 2019.

2. Se Terje Fredwall (2017) for en dyptgående analyse av Nils Christies og Espen Schaannings teoretiske posisjoner og diskusjon om straff som tilsiktet pinepåføring og opplevd pinepåføring.

3. Nils Christie (1982) gjør i særlig grad rede for denne posisjonen i boka Pinens begrensning, mens Espen Schaanning skriver om dette i Den onde vilje (Schaanning, 2002).

4. Justis- og politidepartementet, 2008, s. 22.

5. Se særlig Stortingsmelding av 2008 (Justis- og politidepartementet, 2008, kap. 14) om tilbakeføringsgarantien.

6. Datainnsamlingen ble gjennomført av Ingrid Rindal Lundeberg og Kristian Mjåland.

\section{Referanser}

Andenæs, J. (1976). Statsforvaltningen i Norge (4. utg.). Oslo: Tanum-Norli.

Andenæs, J. (1994). Straffen som problem. Halden: Exil forlag.

Askheim, O.P. (2010). Empowerment - ulike tilnærminger. I O.P. Askheim \&

B. Starrin (Red.), Empowerment i teori og praksis (s. 21-33). Oslo: Gyldendal Akademisk.

Barker, V. (2013). Nordic Exceptionalism revisited: Explaining the paradox of a Janus-faced penal regime. Theoretical Criminology, 17 (1): 5-25. https://doi. org/10.1177/1362480612468935

Bhuller, M., Dahl, G.B., Løken, K.V. \& Mogstad, M. (2016). Incarceration, Recidivism and Employment (NBER Working Paper Series, Working Paper 22648).

Cambridge: National Bureau of Economic Research. https://www.nber.org/ papers/w22648

Bosworth, M. (2007). Creating the responsible prisoner - Federal admission and orientation packs. Punishment \& Society, 9(1): 67-85. https://doi. org/10.1177/1462474507070553

Christie, N. (1982). Pinens begrensning. Oslo: Universitetsforlaget. 
Christie, N. (1987). Tilsiktet pine. Nordisk tidsskrift for kriminalvidenskab, 74, 283-285.

Clemmer, D. (1940). The prison community. New Braunfels, TX: Christopher Publishing House.

Crewe, B. (2009). The Prisoner Society: Power, Adaptation, and Social Life in an English Prison. Clarendon Studies in Criminology. Oxford: Oxford University Press.

Crewe, B. (2011). Depth, weight, tightness: Revisiting the pains of imprisonment. Punishment \& Society, 13(5), 509-529. https://doi.org/10.1177/1462474511422172

Crewe, B., Liebling, A. \& Hulley, H. (2014). Heavy-light, absent-present: rethinking the «weight» of imprisonment. The British Journal of Sociology, 65(3), 387-410. https://doi.org/10.1111/1468-4446.12084

Fredwall, T.E. (2017). Straff som pine. Retfoerd: Nordisk juridisk tidsskrift, 4o(3-4), 24-37 Hentet fra http://retfaerd.org/wp-content/uploads/2018/o1/ retfaerd_3_4_2017_3.pdf

Goffman, E. (1967). Asylums: essays on the social situation of mental patients and other inmates. New York: Anchor Books.

Garland D. (2001) The culture of control: crime and social order in contemporary society. Chicago: University of Chicago Press.

Hannah-Moffat, K. (2000). Prisons that empower. British Journal of Criminology, 4o(3), 510-531. https://doi.org/10.1093/bjc/40.3.510

Hauge, R. (2001). Kriminalitetens årsaker (2. utg.). Oslo: Universitetsforlaget.

Helgesen, J.H.I. (2017). Ny fangebehandling i norske fengsler? Om innsatte rusbrukeres opplevelser av selvbestemmelse og medvirkning. Tidsskrift for velferdsforskning, 20(2), 100-116. Hentet fra https://www.idunn.no/tidsskrift_for_ velferdsforskning/2017/02/ny_fangebehandling_i_norske_fengsler

Justis- og politidepartementet (2002). Retningslinjer for kontaktbetjentarbeidet. Rundskriv KSF 02 / 2002. Hentet fra https://www.regjeringen.no/no/ dokumenter/rundskriv-ksf-02-2002/id109082/

Justis- og beredskapsdepartementet (2002). Lov om gjennomføring av straff mv. LOV2001-05-18-21. Hentet fra https://lovdata.no/dokument/NL/lov/2001-05-18-21

Justis- og politidepartementet (2008). Straff som virker - mindre kriminalitet tryggere samfunn (St.meld. nr. 37 (2007-2008)). Oslo: Departementet.

Kinander, M. (2013). Straffens begrep og begrunnelse i norsk rett - en kritikk. Jussens venner, 48, 155-192. Hentet fra https://www.idunn.no/jv/2013/o3/straffens_ begrep_og_begrunnelse_i_norsk_rett_-_en_kritikk

Kyvsgaard, B. (1998). Den kriminelle karriere. København: Jurist og økonomiforbundets forlag.

Lundeberg, I.R. (2017). Exceptional procedures? Offenders' Experiences of Procedural Justice in Re-entry Work. I T. Ugelvik \& P.S. Smith (Red.), Scandinavian Penal History, Culture and Prison Practice (s. 239-259). London: Palgrave. 
Lundeberg, I.R. \& Mjåland, K. (2016). Rehabilitering og prosedural rettferdighet i kriminalomsorgen. Retford, 153(1), 32-44.

Lundeberg, I.R., Mjåland, K. \& Rye, J.F. (2018). Eksepsjonelle fanger i det eksepsjonelle fengslet. I J.F. Rye \& I.R. Lundeberg (Red.), Fengslende sosiologi. Makt, straff og identitet $i$ Trondheims fengsler (s. 213-237). Oslo: Cappelen Damm Akademisk. https://doi.org/10.23865/noasp.41.ch1o

Lundeberg, I.R. \& Mjåland, K. (under utgivelse). Rus, roller og skjønn. I H.M. Kjærgård Eide \& K.T. Westrheim, Kunnskapsbasert straffegjennomføring (s. 234-262). Fagbokforlaget: Bergen

Maruna, S. (2001). Making good: how ex-convicts reform and rebuild their lives. Washington, D.C.: American Psychological Association.

Mathiesen, T. (1965). The defences of the weak. A sociological study of a Norwegian Correctional Institution. London: Tavistock.

Mjåland, K. \& Lundeberg, I.R. (2014). Penal hybridization: staff-prisoner relationships in a Norwegian drug rehabilitation unit. I H.S. Aasen, S. Gloppen, A.-M. Magnussen \& E. Nilssen (Red.), Juridification and Social Citizenship in the Welfare State (s. 183-202). Cheltenham: Edward Elgar.

Mjåland, K. (2014). "A culture of sharing»: Drug exchange in a Norwegian prison. Punishment \& Society, 16(3), 336-352. https://doi.org/10.1177/1462474514527149

Mjåland, K. (2015a). Makt, legitimitet og motstand:.En etnografisk analyse av rus og rehabilitering $i$ et norsk fengsel (doktoravhandling). Universitetet i Bergen.

Mjåland, K. (2015b). The paradox of control: An ethnographic analysis of opiate maintenance treatment in a Norwegian prison. International Journal of Drug Policy, 26(8), 781-789. https://doi.org/10.1016/j.drugpo.2015.04.020

Mjåland, K. (2016). Exploring prison drug use in the context of prison-based drug treatment. Drugs: Education, Prevention, and Policy, 23(2), 154-162. https://doi.org /10.3109/09687637.2015.1136265

Nilsson, A. (2002). Fånge i marginalen: Uppväkstvillkor, levnadsförhållande och återfall i brott bland fångar (doktoravhandling). Kriminologiska Institutionen, Stockholms universitet.

Revold, M.K. (2015). Innsattes levekår 2014: Før, under og etter soning (Statistisk sentralbyrå (SSB) Rapport 47/15). Oslo/Kongsvinger: Statistisk sentralbyrå.

Sampson, R.J. \& Laub, J.H. (2003). Crime in the making: Pathways and turning points through life. London: Harvard University Press.

Schaanning, E. (2002). Den onde vilje. Oslo: Spartacus forlag.

Schaanning, E. (2009). Den tilsiktede smerten. Oslo: Unipub.

Shammas, V.L. (2017). Prisons of Welfare. Incarceration, Social Democracy and the Sociology of Punishment (Phd.-avhandling). Institutt for sosiologi og samfunnsgeografi, Universitetet i Oslo. 
Skardhamar, T. \& Telle, K. (2012). Post-release employment and recidivism in Norway, Journal of quantitative criminology, 28(4), 629-649. https://doi. org/10.1007/s10940-012-9166-x

Sykes, G.M. (1958). The society of captives: a study of maximum security prison. Princeton: Princeton University Press. 



\section{Om forfatterne}

Karen Christensen er professor ved Sosiologisk institutt ved Universitetet i Bergen. Christensen er mangeårig velferdsforsker og har blant annet vært opptatt av velferdstjenester for eldre og funksjonshemmede samt sosialpolitikk. Hun har publisert nasjonalt og internasjonalt og har undervist i blant annet velferdssosiologi. P.t. er hun redaktør for Tidsskrift for velferdsforskning.

Hans-Tore Hansen er professor ved Sosiologisk institutt ved Universitetet i Bergen. Hansen har forsket på ulike sider ved velferdsstaten. I de siste årene har han særlig forsket på Nav, og tema som velferdsstatens betydning for livsløp samt brukertilfredshet med velferdstjenester. Hansen har også i mange år undervist om blant annet den norske velferdsstaten og ulikhet i velferd.

Ingrid Lundeberg er rettssosiolog, seniorforsker ved Norce og seniorrådgiver for rusreformutvalget. Hennes forskning er omfattende og omhandler blant annet bruk av tvang mot rusmiddelavhengige, politikkutforming og tverrsektorielle tiltak knyttet til innsatsen mot illegal rusmiddelbruk og åpne russcener, soningsforhold og tilbakeføring av lovbrytere etter endt soning av fengselsstraff.

Atle Møen er professor ved Sosiologisk institutt ved Universitetet i Bergen. Møen har forsket på ulike tema omkring velferd og politikk. Herunder har han blant annet forsket på brukerstyrt personlig assistanse for funksjonshemmede. Sentralt i hans publikasjoner er teoretiske problemstillinger, den klassiske sosiologien og politisk ekstremisme. Han har særlig undervist i sosiologisk teori.

Liv Johanne Syltevik er professor ved Sosiologisk institutt ved Universitetet i Bergen. Syltevik har utført mangeårig forskning om enslige mødres 
situasjon i den norske velferdsstaten, og har publisert artikler både nasjonalt og internasjonalt på området. Hun har undervist i familiesosiologi og også publisert innen tema som samboerskap, nye familieliv samt Nav og forholdet til velferdsbrukere.

Kristoffer Chelsom Vogt er førsteamanuensis ved Sosiologisk institutt ved Universitetet i Bergen. Sentrale temaer i Vogts forskning handler om unge og utdanning, herunder yrkesfaglig utdanning samt frafall i videregående skole; intergenerasjonelle relasjoner; klasseanalyser samt kjønnssegregering på arbeidsmarkedet. Han har blant annet undervist i tema om velferd og livsløp. 